\title{
CONSORCIAÇÃO DE ADUBOS VERDES NA CULTURA DE CITROS EM FORMAÇÃO
}

JOSÉ ANTONIO ALBERTO DA SILVA

Engenheiro Agrônomo

Orientador: Prof. Dr. GODOFREDO CESAR VITTI

Dissertação apresentada à Escola Superior de Agricultura "Luiz de Queiroz", da Universidade de São Paulo, para obtenção do título de Mestre em Agronomia, Área de Concentração: Solos e Nutrição de Plantas.

\section{PIRACICABA}

Estado de São Paulo - Brasil

Novembro - 1.995 
Dados Internacionais de Catalogação na Publicação (CIP)

DIVISÃO DE BIBLIOTECA E DOCUAENTAÇAO - Campus "LUiz de Que iroz"/USP

Silva, José Antonio Alberto da

Consorciaçăo de adubos verdes na cultura de citros em formaçăo. Piracicaba, 1995.

116p. ilus.

Diss. (Mestre) - ESALQ

Bibl iografia.

1. Adubo verde 2. Fruta citrica - Adubação verde - Efeito 3. leguminosa como adubo I. Escola Superior de Agricultura Luiz de Queiroz, Piracicaba, sp

CDD 631.874

634.3 
CONSORCIAÇÃO DE ADUBOS VERDES NA CULTURA DE CITROS EM FORMAÇÃO

JOSÉ ANTONIO ALBERTO DA SILVA

Aprovada em: 15 de dezembro de 1995

Comissão Julgadora:

Prof. Dr. Godofredo Cesar Vitti

ESALQ/USP

Prof. Dr. Antonio Luiz Fancelli

ESALQ/USP

Prof. Dr. Domingos Fornasieri Filho

FCAVJ/UNESP

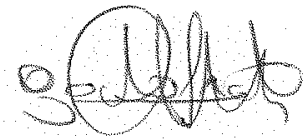

Prof. Dr. GODOFREDO CESAR VITTI Orientador 
“ Louvado seja Deus, que recompensa com sabedoria os que Nele confia" Henrique e Delsa

Aos meus pais,

Henrique e Delsa, pelo exemplo de vida, princípios, incentivo, apóio e amor

\section{DEDICO}

Aos meus irmãos,

Maria Aparecida, João Henrique, Maria Regina, Ana Lúcia, Maurício

e sobrinhos,

Osvaldo Junior, Ana Caroline, Greice e Kimberly

OFEREÇO

"Sucesso é mais atitude doque aptidão" Renata

A Renata,

pelo incentivo, carinho e companheirismo 


\section{AGRADECIMENTOS}

- A Deus, por todas as graças e conquistas proporcionadas durante minha vida;

- Ao Prof. Dr. Godofredo Cesar Vitti, do Depto. de Ciência do Solo da ESALQ/USP, pela orientação e amizade;

- Ao Prof. Dr. Sergio do Nascimento Kronka, pela orientação nas análises estatísticas e amizade;

- A Estação Experimental de Citricultura de Bebedouro (EECB), por ter cedido a área experimental e instalações, seus agrônomos, técnicos e funcionários que muito contribuiram com presteza e amizade;

- A DSJ-Comércio e Representação S/A (Sementes Piraí) e seus agrônomos, por terem fornecido as sementes, apóio técnico e financeiro, atenção e amizade;

- À CAPES - Coordenadoria de Aperfeiçoamento de Pessoal à Nível Superior, pela bolsa de estudo concedida;

- A Escola Superior de Agricultura "Luiz de Queiroz"(ESALQ-USP), por ter me recebido muito bem, como aluno de pós-graduação;

- Ao Departamento de Ciência do Solo da ESALQ/USP, por ter processado as análises químicas de solo e planta, aos professores e funcionários pela atenção e amizade;

- Aos amigos dos cursos de pós-graduação da ESALQ/USP, 'Amigos para sempre !';

- A todos que direta ou indiretamente contribuiram para a realização deste projeto de pesquisa. 


\section{SUMÁRIO}

Página

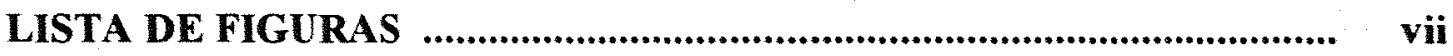

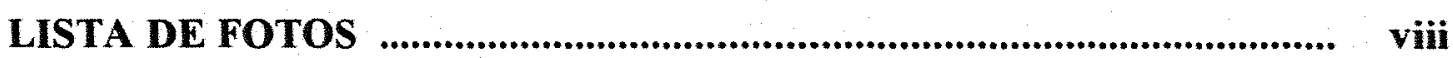

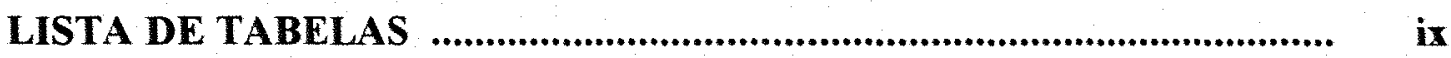

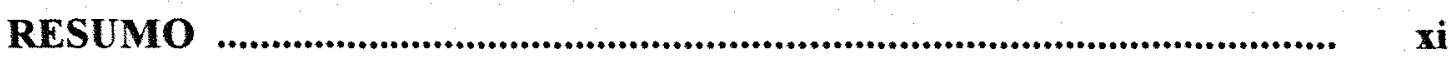

SUMMARY

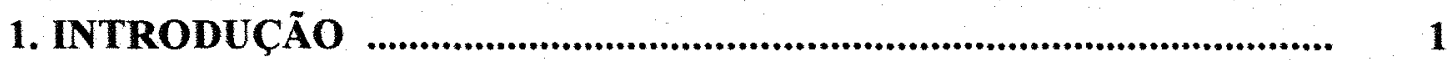

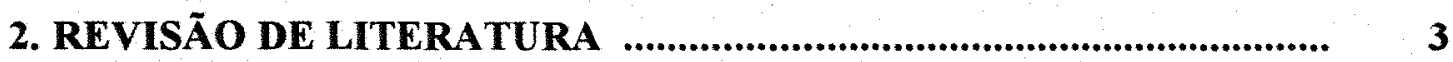

2.1. Generalidades ............................................................................. 3

2.2. Efeitos da adubação verde nas propriedades do solo ......................

2.2.1. Efeitos químicos .......................................................... 4

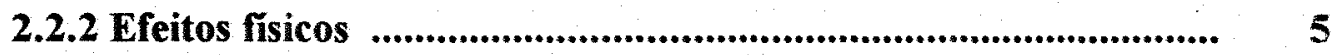

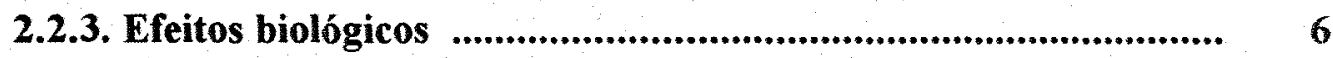

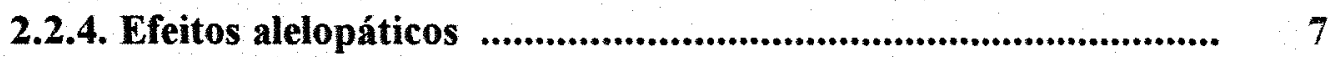

2.2.5. Efeitos indiretos .............................................................. 8

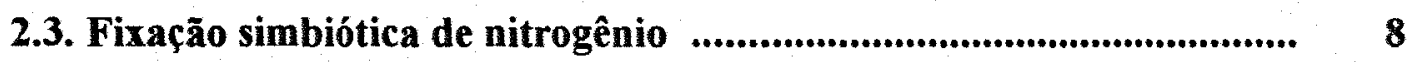

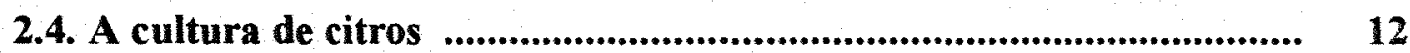

2.5. Corte e incorporação dos adubos verdes ........................................ 14

3. MATERIAL E MÉTODOS

3.1. Características do solo e clima .................................................. 19

3.2. Características do pomar .......................................................... 20

3.3. Características das leguminosas utilizadas .................................... 20

3.4. Delineamento experimental e tratamentos .................................... 27

3.5. Instalação do experimento ........................................................ 28

3.6. Calagem ........................................................................................... 29

3.7. Tratos culturais dos citros ............................................................... 29

3.8. Adubação de manutenção dos citros $\left(\mathrm{N}, \mathrm{P}_{2} \mathrm{O}_{5}, \mathrm{~K}_{2} \mathrm{O}\right) \ldots \ldots . . . \ldots \ldots \ldots . . . . . \quad 30$

3.9. Densidade populacional dos adubos verdes .................................. 31

3.10. Diagnose foliar das plantas de citros ......................................... 31

3.11. Desenvolvimento vegetativo das plantas de citros ....................... . 32

3.12. Incidência de plantas daninhas ............................................... 33

3.13. Análise química do solo ........................................................ 34

3.13.1. Análise química do solo na linha de citros ....................... 35 
3.13.2. Análise química do solo nas linhas das leguminosas ............ $\quad 35$

3.13.3. Análise química do solo após o corte das leguminosas ........ 35

3.14. Amostragem de fitomassa das leguminosas ..................................... 36

3.15. Corte das leguminosas ..................................................................... 36

3.16. Produção de frutos cítricos ............................................................. 37

3.17. Qualidade dos frutos citricos ............................................................ 37

4. RESULTADOS E DISCUSSÃO _.......................................................... 39

4.1. Avaliação da densidade populacional .................................................. 39

4.2. Determinação da altura das leguminosas ............................................ 40

4.3. Avaliação da incidência de plantas daninhas nas parcelas ................ 46

4.4. Identificação das espécies de plantas daninhas incidentes ................ 47

4.5. Resultados das análises foliares dos citros ......................................... 49

4.6. Determinação do diâmetro de caule e volume de copa das plantas

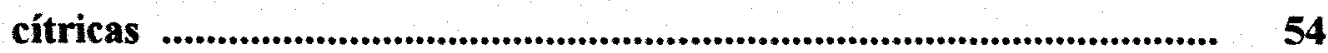

4.7. Resultados das análises químicas do solo ........................................... 56

4.7.1. Análise do solo retirada na projeção da copa dos citros ......... 56

4.7.2. Análise do solo retirada das entrelinhas de citros, antes da semeadura anual dos adubos verdes ........................................ 56

4.7.3. Análise química do solo na entrelinha de citros, após incorporação anual dos adubos verdes ............................................... $\quad 69$

4.8. Produção de fitomassa ............................................................................ 84

4.9. Análise da parte aérea das leguminosas ........................................... 89

4.10. Nutrientes presentes na matéria seca da parte aérea das legumiosas e incorporados ao solo ................................................................. 94

4.11. Produção de frutos cítricos .......................................................... 97

4.12. Análise tecnológica de frutos cítricos .............................................. 99

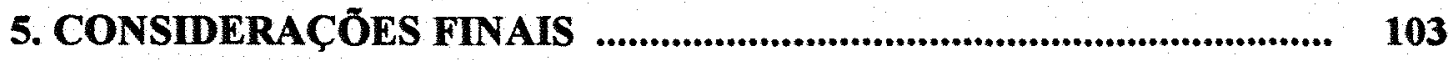

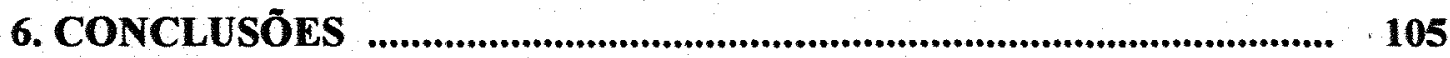

REFERÊNCIAS BIBLIOGRÁFICAS _.............................................. 106

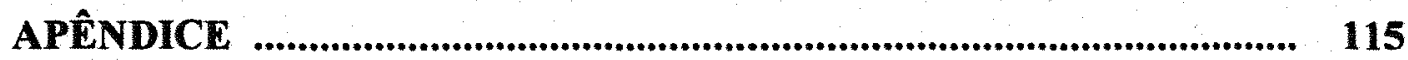




\section{LISTA DE FIGURAS}

Página

FIGURA 1. Croquí da parcela experimental de citros com linhas de adubos verdes nas entrelinhas ................................................... 28

FIGURA 2. Média em $\mathrm{kg} / \mathrm{ha}$ de $\mathrm{N}, \mathrm{P}_{2} \mathrm{O}_{5}$ e $\mathrm{K}_{2} \mathrm{O}$, incorporados ao solo pelas leguminosas

FIGURA 3. Média em $\mathrm{kg} / \mathrm{ha}$ de $\mathrm{Ca}, \mathrm{Mg}$ e $\mathrm{S}$, incorporados ao solo pelas leguminosas

96

FIGURA 4. Média em $\mathrm{kg} / \mathrm{ha}$ de $\mathrm{B}, \mathrm{Cu}$ e $\mathrm{Zn}$, incorporados ao solo pelas leguminosas

FIGURA 5. Média em $\mathrm{kg} / \mathrm{ha}$ de Fe e Mn, incorporados ao solo pelas leguminosas

FIGURA 6. Produção de frutos cítricos 99

FIGURA 7. Índice de eficiência produtiva $\left(\mathrm{kg} / \mathrm{m}^{3}\right)$, no ano agrícola 100 $1992 / 93$ 


\section{LISTA DE FOTOS}

Página

FOTO 1. Aspectos da área experimental com Crotalaria juncea, intercalar ao citros

FOTO 2. Aspectos da área experimental com Crotalaria spectabilis, intercalar ao citros

FOTO 3. Aspectos da área experimental com guandú, intercalar ao citros

FOTO 4. Aspectos da área experimental com mucuna preta, intercalar ao citros

FOTO 5. Aspectos da área experimental com mucuna anã, intercalar ao citros

FOTO 6. Aspectos da área experimental com labe labe, intercalar ao citros

FOTO 7. Aspectos da área experimental com feijão de porco, intercalar ao citros

FOTO 8. Aspectos das parcelas (NPK e 2NPK), com plantas daninhas nativas, intercalar ao citros

FOTO 9. Aspectos do corte com roçadeira dos adubos verdes de porte rasteiro (mucuna preta)

FOTO 10. Aspectos do corte com roçadeira dos adubos verdes de porte herbáceo (guandú) 


\section{LISTA DE TABELAS}

Página

TABELA 1. Resultados das análises químicas das amostras de solo representativas das áreas onde foram implantados os experimentos em novembro de 1989 ........................................ 19

TABELA 2. Tratamentos utilizados ........................................................... 27

TABELA 3. Densidade de sementes e espaçamentos utilizado na semeadura

TABELA 4. Quantidades de adubo aplicado no citros nos quatro anos agrícolas .....................................................................................

TABELA 5. Faixa para interpretação de teores de macro e de micronutrientes nas folhas de citros, geradas na primavera, com seis meses de idade, de ramos com frutos

TABELA 6. Padrões de fertilidade para interpretação de resultados de análise de solo para citros

TABELA 7. Interpretação preliminar de resultados de análise de solo para enxofre e micronutrientes ............................................

TABELA 8. Densidade de semeadura utilizada e número médio de plantas sobreviventes por metro linear, médias obtidas nos quatro anos agrícolas

TABELA 9. Resultado da medição da altura das plantas nas parcelas intercalares ao citros nos anos agrícolas, 1989/90, 90/91, 91/92 e $92 / 93$

TABELA 10. Porcentagem média de plantas daninhas observada nas parcelas

TABELA 11. Espécies de plantas daninhas de maior ocorrência nas parcelas, nos anos agrícolas 1989/90, 90/91, 91/92 e 92/93 ...

TABELA 12. Teores de nutrientes resultantes das análises químicas das folhas dos citros, nos anos agrícolas 1989/90, 90/91, 91/92 e 92/93

TABELA 13. Resultado das medições para determinação do diâmetro do tronco $(\mathrm{cm})$ e volume de copa $\left(\mathrm{m}^{3}\right)$, ano agrícola $1989 / 90$, 90/91, $91 / 92$ e $92 / 93$ 
Página

TABELA 14. Resultado das análises químicas de solo na projeção da copa dos citros, nos anos agrícolas de 90/91, 91/92 e 92/93

TABELA 15. Resultado das análises químicas de solo nas linhas de legumi nosas (entre linhas de citros), na profundidade $0-20 \mathrm{~cm}$,

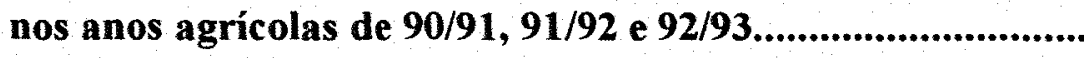

TABELA 16. Resultado das análises químicas de solo nas linhas de leguminosas (entre linhas de citros), na profundidade $20-40 \mathrm{~cm}$, nos anos agrícolas de 90/91, 91/92 e 92/93

TABELA 17. Resultado das análises químicas de solo no dia da incorporaç̃o dos adubos verdes, na profundidade $0-20 \mathrm{~cm}$, nos anos agrícolas de $89 / 90,90 / 91,91 / 92$ e $92 / 93$

TABELA 18. Resultado das análises químicas de solo três meses após incorporação dos adubos verdes, na profundidade $0-20 \mathrm{~cm}$, nos anos agrícolas de 89/90, 90/91, $91 / 92$ e 92/93

TABELA 19. Resultados das análises química de solo $(0-20 \mathrm{~cm})$, seis meses após a incorporação dos adubos verdes, nos anos agrícolas de 1989/90, 90/91, 91/92 e 92/93

TABELA 20. Produção de matéria verde, porcentagem de umidade e matéria seca das partes aéreas das leguminosas, anos agricolas de 1989/90, 90/91, 91/92 e 92/93

TABELA 21. Teores de nutrientes resultantes das análises químicas da parte aérea das eguminosas (matéria seca), ano agrícola $1989 / 90,90 / 91,91 / 92$ e $92 / 93$

TABELA 22. Quantidade média de nutrientes incorporados ao solo pelas leguminosas após quatro anos de plantio intercalar ao citros

TABELA 23. Resultados da produção de frutos cítricos, nos anos agrícolas de 1990/91, $91 / 92$ e $92 / 93$

TABELA 24. Valores médios das caracteristicas de qualidade dos frutos de laranjeira "Pera"sobre tangerineira Cleópatra, nos anos agrícolas de $1991 / 92$ e $1992 / 93$

TABELA 25. Dados climáticos no período junho / 1989 a junho / 1993 .... 


\title{
CONSORCIAÇÃO DE ADUBOS VERDES NA CULTURA DE CITROS EM FORMAÇÃO
}

\author{
Autor: JOSÉ ANTONIO ALBERTO DA SILVA \\ Orientador: Prof. Dr. GODOFREDO CESAR VITTI
}

\section{RESUMO}

Com o objetivo de estudar a utilização do cultivo intercalar de adubos verdes em pomares de citros em formação, foi instalado e conduzido durante quatro anos agrícolas, um experimento de campo na Estação Experimental de Citricultura de Bebedouro, Estado de São Paulo, em unidade de solo classificada como Latossolo Vermelho Escuro, epieutrófico, endoálico, A moderado, textura média, onde utilizou-se nove tratamentos que constaram de adubação NPK recomendada e adubação $2 \mathrm{~N}, \mathrm{P}$ e K nas plantas cítricas, sem adubos verdes nas entrelinhas e adubação PK nas plantas cítricas, com os adubos verde Crotalaria juncea, Crotalaria spectabilis, Cajamus cajan (guandu), Mucuna aterrima (mucuna preta), Mucuna deeringiana (mucuna anã), Dolichos lablab (labe labe) e Canavalia ensiformis (feijão de porco), semeadas nas entrelinhas da laranjeira "Pera" (Citrus sinensis L. Osbeck), enxertada em tangerineira "Cleópatra" (Citrus reshi Hort. ex tan.), plantadas em maio de 1987. Avaliou-se após a semedura e incorporação em quatro anos, o comportamento das espécies na área, a sobrevivência, o desenvolvimento, produção de fitomassa, composição química e cobertura do solo, bem como, o desenvolvimento das plantas de citros, produção, 
qualidade dos frutos e estado nutricional. Com os resultados obtidos, pode-se concluir que o emprego de adubos verdes intercalares, contribue para a redução da aplicação de nitrogênio mineral em pomares de citros, em formação; a Crotalaria juncea é a espécie de adubo verde mais indicada para o pomar de citros em formação; a adubação verde reduz a incidência de plantas daninhas e incrementa a reciclagem de nutrientes na formação de pomares de citros. 


\title{
CONSORTIATION OF GREEN MANURES IN FORMATION OF CITRUS ORCHARDS
}

\author{
Author: JOSÉ ANTONIO ALBERTO DA SILVA \\ Adviser: Prof. Dr. GODOFREDO CESAR VITTI
}

\section{SUMMARY}

To study the utilization of green manure interline culture in citrus orchard, was carried out for four years in the Citrus Experimental Station of Bebedouro (latitude $20^{\circ} 53^{\prime} 16^{\prime \prime} \mathrm{S}$, longitude $48^{\circ} 28^{\prime} 11^{\prime \prime} \mathrm{W}$ and altitude 601 meter), São Paulo State, in a Haplustox, a experiment with none treatment: recomended NPK fertilization, 2N, P and $\mathrm{K}$ fertilization for citrus plants without green manure interlines, PK fertilization for citrus plants with the following green manures sowed enterlines of sweet orange 'Pera' (Citrus sinensis L. Osbeck), on Cleopatra (Citrus reshi Hort.) planted in may of 1987. Crotalaria juncea, Crotalaria spectabilis, Cajamis cajan, Mucuna aterrima, Mucuna deeringiana, Dolichos lablab and Canavalia ensiformis, were evaluated after growing and incorporation the character of the species, survival, development, phytomass prodution, chemical composition, soil covering, and also the development and nutrition state, prodution and fruit quality of 'Pera'sweet orange. It could the conclude that the use of green manure interlines could, reduce the aplication of mineral nitrogen and Crotalaria juncea was the best green manure for matured citrus orchards, and that green manure reduced the plant invader and increment the nutrients reciclying in citrus orchards. 


\section{INTRODUÇÃO}

A citricultura brasileira constitui-se no maior expoente mundial, em extensão, produção, exportação de suco concentrado e de sub-produtos cítricos Dentre as tecnologias disponiveis atualmente, encontram-se porta-enxertos e copas selecionadas, informações sobre exigências nutricionais e diagnose foliar, tecnologia de aplicação de defensivos no controle de pragas e doenças e conhecimento sobre a adubação com macro e micronutrientes. Entretanto, com a recente expansão acelerada da citricultura no Brasil e a atual politica agrícola e econômica vigente, esta atividade passa por séria críse em função da elevação dos custos de produção e queda nos preços pela laranja produzida, tornando premente a adoção de técnicas capazes de otimizarem a continuidade da atividade citrícola. Entre as alternativas disponíveis cita-se o emprego de espécies vegetais capazes de levarem a substituição parcial e/ou total de adubos químicos, a maior cobertura do solo para o controle de plantas daninhas, controle de erosão e a reciclagem de nutrientes lixiviados.

A adoção da adubação verde, ou seja a prática de cultivo e incorporação de plantas com a finalidade de preservar e/ou restaurar o teor de matéria orgânica e a fertilidade dos solos com seu material vegetal, constitui-se numa das alternativas disponíveis. A principal finalidade do emprego das leguminosas para a adubação verde é reduzir a aplicação de nitrogênio via adubo químico, pelo fato das raízes dessas plantas fixarem o nitrogênio do ar, através de simbiose com bactérias do gênero Rhizobium, enriquecendo o solo com esse macronutriente, além da presença de um sistema radicular ramificado e profundo, capaz de possibilitar a assimilação de nutrientes percolados para as camadas subsuperficiais. São responsáveis pela produção de material orgânico geralmente rico em macro e micronutrientes, capazes de propiciarem aumento da 
capacidade de troca catiônica do solo e a capacidade de retenção de água, ampliando as condições favoráveis para o desenvolvimento microbiano no solo, além de auxiliar na conservação do solo, no controle de nematóides e possuir efeito alelopático sobre diversas plantas invasoras.

A familia das leguminosas compõe-se de numerosas espécies, que apresentam variações quanto ao ciclo vegetativo, produção de material vegetal, porte e ampla diversidade de exigências em relação a clima e solo.

Assim, o trabalho objetiva avaliar durante quatro anos agrícolas, os efeitos da consorciação e incorporação ao solo de diferentes leguminosas na cultura de citros em formação, sobre o fornecimento de nutrientes ao solo e às plantas cítricas, no controle de plantas daninhas, na produção e no desenvolvimento das plantas cítricas bem como o comportamento dessas espécies em Bebedouro, Estado de São Paulo. 


\section{REVISÃO DE LITERATURA}

\subsection{Generalidades}

Os adubos verdes são plantas utilizadas com a finalidade de serem incorporadas ao solo fornecendo material orgânico, nitrogênio e outros nutrientes, com o intuito de melhorar as características físicas, químicas e biológicas dos solos cultivados.

A adubação verde quando bem emprega, traz vantagens tais como a cobertura do solo e, consequentemente, menor radiação solar direta; melhores condições fisicas e biológicas do solo, devido ao maior aprofundamento das raizes; aumento no teor de matéria orgânica e nutrientes do solo; aumento do nitrogênio disponível, devido à fixação do nitrogênio atmosférico; controle de pragas e doenças e influem no equilibrio dos microorganismos, alterando a composição da fauna e da flora do solo. (IAPAR, 1985).

Quando se deseja um efeito significativo na utilização da adubação verde, é fundamental a frequência (continuidade) de sua aplicação (IGUE, 1984), sendo que para produzir satisfatóriamente, os solos deveriam ter no mínimo de 2 a $3 \%$ de matéria orgânica (GUSTAFSON, 1941; THOMPSON, 1952).

Segundo SILVA \& CHAVES, (1966), a matéria orgânica tem múltiplos efeitos nas propriedades químicas, liberando nutrientes, aumentando a capacidade de troca cationica e liberando ácidos que atuam solubilizando minerais do solo; nas propriedades fisicas, aumentando a capacidade de retenção de água, diminuindo com isso a lixiviação e melhorando a estrutura dos solos e nas biológicas, propiciando principalmente, condições favoráveis para a atividade microbiana do solo.

Em termos de fertilidade do solo, a propriedade de conferir maior capacidade de troca de cátions da matéria orgânica aos solos, é de fundamental importância, 
conforme observado por VERDADE (1956), RAIJ (1969) e VITTI et al. ( 1979), não só para os solos do Estado de São Paulo, como também da maioria dos solos do País que apresentam em sua fração argila, minerais com baixa capacidade de retenção de cátions.

Embora autores como FREITAS (1971) e MALAVOLTA (1977), tenham mostrado o alto custo do quilo de nitrogênio mineral, desde aspectos industriais até os de transporte e aplicação, a prática de adubação verde em solos brasileiros tem sido pouco explorada e segundo KIEHL (1959), isto é devido, em especial, pela resistência dos agricultores em aceitar tal prática, pelo desconhecimento dos beneficios que a mesma pode trazer ao solo.

\subsection{Efeitos da adubação verde nas propriedades do solo}

\subsubsection{Efeitos químicos}

A fertilidade do solo é bastante influenciada pelos efeitos dos adubos verdes.

Os principais efeitos esperados são: o aumento do teor de matéria orgânica do solo, ao longo dos anos, pela adição da fitomassa total e outros organismos; o aumento da disponibilidade de macro e micronutrientes no solo, em formas assimiláveis pelas plantas; o aumento da CTC efetiva do solo; o auxílio na formação de ácidos orgânicos, fundamentais ao processo de solubilização dos minerais do solo; a diminuição nos teores de alumínio trocável (complexação); a elevação do $\mathrm{pH}$ do solo e consequentemente diminuição da acidez (principalmente pela ação das leguminosas) e o incremento da capacidade de reciclagem e mobilização de nutrientes lixiviados ou pouco solúveis que se encontram em camadas mais profundas do perfil do solo, que em outras situações estariam perdidos ou não-disponiveis ao aproveitamento pelas culturas com sistema radicular superficial. DERPSCH \& CALEGARI (1985), observou que o efeito residual da adubação verde, em rotação com os cultivos comerciais, melhora o teor de matéria orgânica, a fertilidade e a produtividade do solo, onde através de vários testes com adubo verde de inverno, obteve rendimentos significativamente superiores ao pousio, quando feijão, soja e milho foram semeados sobre a resteva de nabo forrageiro, aveia preta e tremoço, respectivamente. 
ASLANDER \& NEEME (1965), concluiram que o emprego de adubo verde gramínea, influenciou favoravelmente na solubilização do potássio e possibilitou assimilar maior quantidade desse elemento. MIYASAKA et al. (1965), estudando o comportamento das fitomassas de leguminosas e de gramíneas, quando incorporadas ao solo, pouco antes do plantio de feijoeiro e os efeitos dessas fitomassas nas propriedades químicas, fisicas e biológicas do solo, verificaram que a incorporação ou cobertura morta de soja perene, aumentou a disponibilidade de potássio no solo, proporcionando maior teor desse elemento nas folhas do feijoeiro.

Uma das propriedades mais importantes dos solos é a CTC, responsável pelo equilíbrio entre as fases sólidas e líquidas e pela diminuição das variações das concentrações de íons resultantes de diferentes práticas agrícolas. Dois tipos de CTC são observadas: uma chamada de CTC permanente que está ligada a argila, e a CTC variável ou dependente da matéria orgânica e da argila. Na maioria dos solos agrícolas, a matéria orgânica apresenta a maior contribuição para a CTC dependente de $\mathrm{pH}$, demonstrando ser a argila caracterizada por baixa atividade (PAVAN et al., 1985). Nesse caso, o manejo da matéria orgânica torna-se fundamental para a melhoria das propriedades desses solos.

A utilização da adubação orgânica, ao longo dos anos, tende a aumentar o teor de húmus no solo. Esse húmus tenderá a aumentar a CTC, fundamental para a manutenção da fertilidade do solo e nutrição das plantas.

\subsubsection{Efeitos físicos}

Os efeitos dos resíduos dos adubos verdes ou de outras plantas nas características físicas do solo são função da qualidade, quantidade e tipo de manejo dado ao material adicionado, bem como dos fatores climáticos e das características específicas do solo. A estrutura, a capacidade de retenção de água, a consistência, a densidade, a infiltração, a porosidade, a aeração e a condutividade elétrica são algumas características que sofrem influência direta dos resíduos. 
Quando a superficie do solo está protegida pela cobertura morta, não sofre ação de desagregação pelo impacto direto da gota de chuva e selamento da superficie do solo facilitando a infiltração e consequente diminuição do escorrimento superficial.

MARUN et al. (1986), verificaram em solos argilosos e arenosos os beneficios com o uso de cobertura com gramíneas, na economia de água, na redução da temperatura do solo, na diminuição dos gastos com capinas, no estado nutricional das plantas e na produtividade da cultura do cafeeiro.

\subsubsection{Efeitos biológicos}

A presença de material orgânico no solo é determinante na atividade e população dos microorganismos, uma vez que a matéria orgânica é, antes de mais nada, fonte de energia para os organismos do solo.

Em solos manejados no sistema convencional, observa-se o menor desenvolvimento de microorganismos, devido as constantes oscilações de temperatura e umidade do solo pela menor cobertura.

Conforme SIDIRAS et al. (1984), no plantio direto há maior e mais profunda distribuição de nódulos. A importância de nódulos e raízes em maior profundidade no solo reside no fato de que a planta e o simbionte estão menos sujeitos a perdas d'água e a oscilações térmicas, o que significa maior estabilidade na fixação do nitrogênio em plantio direto.

Conforme SHARMA et al. (1982) e SANTOS \& RUANO (1987), a prática da adubação verde pode se constituir num dos métodos mais valiosos e baratos no controle de nematóides, desde que se opte por espécies adequadas. Diversos são os gêneros e as espécies de fitonematóides existentes, sendo que alguns apresentam maior importância agrícola, existindo especificidades por determinadas culturas.

Trabalhos conduzidos pelo IAPAR (1985), mostram que, das diferentes espécies de plantas cultivadas, algumas contribuem para o incremento populacional dos nematóides, outras são antagônicas, ou seja, abaixam sua população no solo. Semelhantes efeitos tem sido observados em diferentes espécies de plantas usadas como adubos verdes. De acordo com SANTOS \& RUANO (1987), as crotalárias, mucunas e o guandú 
são as espécies de verão que apresentam melhores efeitos no controle populacional dos nematóides. Entre as gramíneas de inverno destaca-se a aveia, o centeio, o azevém e a cevada e entre as leguminosas a alfafa e a serradela, bem como, a aspérgula (cariofilacea) tem sido promissoras. Esses resultados referem-se aos nematóides mais problemáticos e mais disseminados no Paraná: Meloidoyne incognita raça 3 e Meloidoyne javanica.

É possivel que algumas espécies de plantas, ao se decomporem no solo, liberem ácidos e substâncias aleloquímicas dos tecidos e raizes, interferindo nas larvas e ovos de nematóides no interior dos tecidos das plantas. Além dos resíduos vegetais acumulados no solo, estas plantas aumentam a atividade biológica, aumentando o número de organismos tendendo a manter um equilíbrio natural de espécies sem comprometer o desenvolvimento das culturas.

\subsubsection{Efeitos alelopáticos}

A alelopatia pode ser definida como sendo todas as interferências desencadeadas entre plantas e microorganismos, provocadas pela liberação de substâncias químicas por eles elaboradas, através dos tecidos vivos ou mortos Compreende, portanto, efeitos benéficos e prejudiciais, provocados por um organismo sobre outro.

Segundo ALMEIDA (1988), os residuos sobre o solo como cobertura morta proporcionam efeitos alelopáticos mais pronunciados e prolongados, visto que ocorre uma concentração dos aleloquímicos na superficie, bem como os mesmos são liberados mais lentamente.

O efeito alelopático pode ser indireto, através da exudação de substâncias tóxicas pelos microorganismos, sendo isto verificado em plântulas de trigo, semeado no sistema de plantio direto, cuja fitotoxidade é causada pela fitotoxina patulina, produzida pelo fungo Penicillium urticae, que se desenvolve na resteva de trigo. Os sintomas dos efeitos alelopáticos nas culturas, são os seguintes: redução da germinação, falta de vigor vegetativo ou morte das plântulas, amarelecimento ou clorose das folhas, redução de perfilhamento e atrofiamento ou deformação das raizes. (ALMEIDA, 1988). 


\subsubsection{Efeitos indiretos}

$\mathrm{Na}$ apicultura, das diferentes plantas usadas como adubos verdes, algumas produzem grande quantidade de néctar e pólen, que poderão ser aproveitados pelas abelhas. O nabo forrageiro, o cornichão, a alfafa, a chícharo, o tremoço, a ervilhaca forrageira, os trevos, dentre outros, são espécies melíferas de outono/inverno, já dentre as espécies de primavera/verão destacam-se: o girassol, o melilotus, o guandú e as crotalarias. As abelhas, por seu turno, melhoram a produção e consequentemente a produtividade de diversas culturas agrícolas.

Diversas espécies de plantas utilizadas na adubação verde, prestam-se à utilização forrageira, com produção de forragem de alta qualidade e elevados teores de proteina. A utilização desse material pode ser feito através de pastoreio, silagem ou fenação, além do consórcio de leguminosas com gramíneas na obtenção de forragem de boa qualidade e de composição equilibrada. Num consórcio de aveia-preta $\mathrm{x}$ ervilhaca comum, por exemplo, produz-se forragem de elevado teor protéico, além de deixar resíduos no solo que apresentam relação $\mathrm{C}: \mathrm{N}$ intermediária, facilitando o cultivo da cultura posterior (por exemplo, o milho), sem ocorrer déficite temporário de nitrogênio no solo.

\subsection{Fixação simbiótica de nitrogênio}

As leguminosas são mais utilizadas que as gramíneas, por serem, principalmente, mais ricas em nitrogênio, por fixá-lo do ar $\left(\mathrm{N}_{2}\right)$, graças à associação simbiótica entre suas raizes e bactérias do gênero Rhizobium, produzindo um ganho líquido de nitrogênio para o solo, sendo os demais elementos apenas reciclados (COSTA, 1989). Segundo a FAO (1985), o ar tem $80 \%$ de nitrogênio $\left(\mathrm{N}_{2}\right)$, correspondendo a cerca de $6.400 \mathrm{~kg}$ do elemento sobre cada hectare, sendo que as plantas leguminosas podem utilizá-lo, em simbiose com as bactérias do gênero Rhizobium.

A matéria orgânica, natural ou adicionada, também funciona como fonte de energia para os organismos de vida livre que fixam $\mathrm{N}_{2}$ do ar. Por outro lado, o mato e o 
adubo verde podem buscar nutrientes de camadas mais profundas do perfil, trazendo-os para a superficie, onde predominam as raizes absorventes da laranjeira. Além disso, as raizes de adubo verde e do mato fazem, por assim dizer, uma subsolagem biológica, criando pequenos canais no solo por onde circulam a água e o ar (RUSSELL et al., 1981).

A fixação simbiótica do nitrogênio $\left(\mathrm{N}_{2}\right)$, depende de uma série de fatores tais como: características genéticas da bactéria, espécie de leguminosa e condições gerais do solo. Em média, a fixação é estimada em $10 \mathrm{~g}$ de nitrogênio por metro quadrado de solo por ano, o que significa aproximadamente $100 \mathrm{~kg}$ de nitrogênio por hectare (MYASAKA et al. 1984). As leguminosas devem ser inoculadas para que fixem e incorporem quantidades de nitrogênio da ordem de $100 \mathrm{~kg}$ por hectare por ano (GALETI \& TRANI, 1987). MELLO (1978), estimou que no Brasil, as quantidades de $\mathrm{N}$ fixadas pelas principais leguminosas cultivadas são: $207 \mathrm{~kg} / \mathrm{ha}$ ano - feijão guandú; $190 \mathrm{~kg} / \mathrm{ha}$ ano feijão de porco; $170 \mathrm{~kg} / \mathrm{ha}$ ano - soja otootan; $150 \mathrm{~kg} / \mathrm{ha}$ ano - mucuna cinza; e $154 \mathrm{~kg} / \mathrm{ha}$ ano - crotalarias.

A fixação biológica de nitrogênio atmosférico é o processo onde ocorre a redução do $\mathrm{N}_{2}$ por ação da enzima nitrogenase, presente em alguns microorganismos de vida livre, ou em aqueles associados a alguns grupos de plantas. A associação rizóbio/leguminosas é a que apresenta maior expressão nos estudos atuais de processos microbiológicos, porém, existem outras associações, tais como, os fixadores de vida livre (Azobacter, Clostridium, Cianobactérias, Enterobactérias, Bacillus e outros); as associações não-simbióticas na rizosfera e filosfera de plantas; as associações actinorrízicas; as associações micorrízicas; as associações das cianobactérias ( com Azolla, com fungos, com cicadáceas, com Gunnera); as associações de Azospirillum em gramíneas; etc.

As leguminosas podem fixar durante um período vegetativo, dependendo da espécie e condições de solo e clima, de zero a mais de $200 \mathrm{~kg} / \mathrm{ha}$ de nitrogênio. $\mathrm{O}$ aproveitamento pelas culturas que sucedem o adubo verde é de aproximadamente 12 a $25 \%$ em solos argilosos (DERPSCH, 1979). Quantidades maiores de nitrogênio fixado 
simbióticamente são observados em leguminosas perenes, como é o caso da leucena, que chega a fixar até $400 \mathrm{~kg} / \mathrm{ha}$.ano (KLUTHCOUSKI, 1980).

Para atingir o máximo de eficiência nos processos de nodulação e fixação de nitrogênio, é necessária a interação dos fatores ambientais (temperatura, aeração, luz e fotossintese), dos fatores edafológicos (matéria orgânica, umidade, relação $\mathrm{C}: \mathrm{N}$, acidez e alcalinidade, macro e micronutrientes, salinidade, produtos não tóxicos e compatíveis com a inoculação) e dos fatores biológicos (presença de rizóbios ineficientes), que irão influir no desenvolvimento da planta hospedeira e consequentemente na maior ou menor nodulação e fixação do $\mathrm{N}_{2}$. Ao observar o comportamento de três leguminosas quanto à nodulação, em Latossolo Roxo álico do Sudeste do Paraná, com duas estirpes de Rizobium e duas doses de fertilizantes nitrogenados ( $30 \mathrm{~kg} \mathrm{~N} / \mathrm{ha}$ e $60 \mathrm{~kg} \mathrm{~N} / \mathrm{ha}$ ), na forma de sulfato de amônio), CALEGARI (1986), concluiu que a mucuna cinza foi a de maior capacidade de sofrer infecção radicular. A aplicação de nitrogênio alterou a nodulação: a dose de $30 \mathrm{~kg} \mathrm{~N} / \mathrm{ha}$ a inibiu no feijão de porco e diminuiu em $18 \%$ o peso de nódulos da mucuna-cinza; a dose de $60 \mathrm{~kg} \mathrm{~N} / \mathrm{ha}$, além da inibição da nodulação do feijão de porco, reduziu a da mucuna cinza em $62 \%$ e apresentou menores valores em Crotalaria grantiana.

Segundo IGUE (1984), cerca de $2 / 3$ do $\mathrm{N}$ total das leguminosas é de origem atmosférica $\left(\mathrm{N}_{2}\right)$ e o restante absorvido, numa porcentagem total de $\mathrm{N}$ que varia entre 1,5 e 3,0\% no resíduo orgânico.

FRANCO \& SOUTO (1984), enfatizam que as leguminosas com sistema radicular profundo, aumentam a eficiência de utilização dos adubos, uma vez que trazem às camadas superficiais do solo alguns nutrientes que seriam perdidos por lixiviação, principalmente $\mathrm{K}, \mathrm{Ca}, \mathrm{Mg}$ e $\mathrm{NO}_{3}$, funcionando também como "agente minerador" dos nutrientes de reduzidas disponibilidades ( $\mathrm{P}$ e $\mathrm{Mo}$ ), tornando-se mais disponíveis às culturas subsequentes. Os tremoços e o trigo mourisco possuem a propriedade de solubilizar e assimilar o fósforo, a partir dos fosfatos minerais insolúveis em água e ácidos fracos, formando humo-fosfatos, assimiláveis pelas culturas (CRUZ, 1985). 
$\mathrm{O}$ teor de $\mathrm{N}$ total, nas suas diferentes formas, no solo varia com uma série de fatores, destacando-se, clima, vegetação, topografia, material de origem, $\mathrm{pH}$, atividade microbiana, propriedades fisicas do solo e manejo (MELO \& CARDOSO, 1975).

Com relação ao solo, mais de $90 \%$ do nitrogênio da camada superficial ocorre nas formas orgânicas, sendo que a camada superficial de muitos solos cultivados contém entre 0,06 a $0,3 \%$ de $\mathrm{N}$ total (OLIVEIRA, 1987). A fração mineral do nitrogênio do solo representa uma porcentagem muito pequena do nitrogênio total e é constituída por $\mathrm{N}$-amoniacal solúvel, trocável e fixado, $\mathrm{N}$-nitrito e $\mathrm{N}$-nitrato, variando muito de um solo para outro e no mesmo solo, em função do seu uso e manejo, bem como, da época do ano em que as amostras são obtidas (VIETS JUNIOR \& HAGEMANN, 1971).

MELLO (1988), descreveram que a mineralização do $\mathrm{N}$ dos adubos verdes (leguminosas), inicia-se quase que imediatamente após a incorporação do material ao solo, por ser favorável a relação C:N. Entretanto, se uma quantidade muito grande de material verde for enterrado, o plantio deverá ser feito, no mínimo, uma semana após, por ser a rápida decomposição desfavorável ao desenvolvimento das plântulas e poder favorecer o aparecimento de parasitas. Além disso, poderá haver competição entre as plantas e os microorganismos para a aquisição de outros nutrientes, além do $\mathrm{N}$. A velocidade de decomposição vai diminuindo à medida que a relação $C: N$ vai se estreitando, tendendo para valores entre 10 e 12 , que é a relação normal da matéria orgânica estável nos solos.

Solos bem drenados, pouco ácidos e em equilibrio com o ambiente apresentam relação $\mathrm{C}: \mathrm{N}$ em torno de 10 a 12 . Em solos com relação $\mathrm{C}: \mathrm{N}$ alta, inicialmente há um consumo do nitrato existente no solo, que é incorporado ao protoplasma dos microorganismos. A matéria orgânica perde carbono, que é convertido em $\mathrm{CO}_{2}$. A relação $\mathrm{C}: \mathrm{N}$ decresce e o processo todo resulta em uma imobilização líquida do nitrato do solo. Com o redução da relação $\mathrm{C}: \mathrm{N}$, surgem condições de mineralização, com liberação de amônio, que é logo convertido em nitrato (TISDALE \& NELSON, 1975). 


\subsection{A cultura de citros}

A boa estrutura do solo, contribui para o movimento adequado da água e do ar. A passagem abusiva de máquinas no pomar ou a pulverizacão da camada arável por implementos agrícolas são prejudiciais à manutenção da estrutura adequada. A incorporação e/ou manutenção da matéria orgânica no solo é essencial para manter uma boa estrutura, além de contribuir para reduzir o risco de lixiviação de cátions, particularmente de potássio, em solos arenosos (MALAVOLTA, 1985).

Para JONES \& EMBLETON (1973), as funções primárias das leguminosas no pomar são: melhorar a estrutura do solo, impedir a erosão, melhorar as condições de fertilidade, tornando os nutrientes mais disponíveis, adicionar nitrogênio e remover o excesso de água. Do ponto de vista da planta cítrica, entretanto, o adubo verde se comporta como uma planta daninha, pois pode competir por água, nutriente, sol e pelo espaço aéreo e do solo. Quando bem usados, entretanto, esses inconvenientes pesam relativamente pouco, sendo compensados pelas vantagens que seu cultivo apresenta.

Entre as espécies utilizadas na prática da adubação verde, destaca-se o labe labe devido à sua adaptação às condições tropicais, facilidade de cultivo, flexibilidade de manejo, multiplicidade de uso e capacidade de aproveitamento dos resíduos de adubação das culturas anteriores (BULISANI, 1974).

A Crotalaria juncea apresenta grande resistência à seca, pois seu sistema radicular atinge até $4,6 \mathrm{~m}$, sendo que $80 \%$ dele encontra-se nos primeiros $30 \mathrm{~cm}$ do solo (SCARANARI \& INFORZATO, 1952) e contitui-se no adubo verde com maior rendimento em material verde e de incorporação de $\mathrm{N}, \mathrm{P}_{2} \mathrm{O}_{5}$ e $\mathrm{K}_{2} \mathrm{O}$, quando comparada com mucuna preta e soja cultivar Santa Rosa. (GLORIA et al., 1980)

Antes da implantação de um pomar, pode-se efetuar a semeadura de leguminosas e incorpora-las antes do plantio. A semeadura da soja, do amendoim, como culturas econômicas, também pode ser considerada.

Em se tratando de pomar implantado alguns pontos devem ser lembrados segundo JONES \& EMBLENTON (1973): o adubo verde pode restringir o movimento 
do ar e a radiação do solo em períodos frios; pode dificultar as operações de pulverização e colheita; a incorporação de um adubo verde muito fibroso, maduro, pode ser mais prejudicial do que benéfica devido à imobilização temporária do nitrogênio pela relação $\mathrm{C}: \mathrm{N}$ muito alta do material.

De acordo com CAETANO (1980), em pomares formados no espaçamento de oito metros entre linhas podem ser plantadas quatorze linhas de soja no $1^{\circ}$ ano, dez no $2^{\circ}$ e oito no $3^{\circ}$; entre as linhas de soja o espaçamento varia entre 47 e $50 \mathrm{~cm}$. Deve-se dar atenção para os seguintes pontos lembrados também por BRAGA (1986): deixar uma faixa entre os citros e a cultura intercalar para evitar competição e dano aos primeiros na colheita; adubar a cultura intercalar; evitar o borrifo dos defensivos usados na cultura intercalar sobre os citros; incorporar os restos da cultura intercalar após sua colheita; fazer os tratamentos usuais dos citros (pulverizações, adubações, capinas), enquanto cresce e produz a cultura intercalar.

JONES \& EMBLETON (1973), lembram que quando há dificuldade em se cultivar um adubo verde no pomar, pode-se tirar proveito do mato que deve ser ceifado na primavera/verão e gradeado no fim das chuvas.

Não se deve pensar, porém, que o adubo verde (ou as demais fontes de matéria orgânica) consigam aumentar permanentemente, o teor de matéria orgânica no pomar. PROEBSTING (1952), não observou aumentos nos teores de matéria orgânica, de nitrogênio total e na capacidade de armazenamento de água, depois de 25 anos da aplicação. Entretanto, houve efeito favorável na velocidade de infiltração de água, consequência do melhoramento promovido na estrutura do solo. Tal melhoramento é causado pela ação dos microorganismos na matéria orgânica, que funciona como cimento das partículas de solo, o que leva à formação de agregados (MARTIN \& WAKSMAN, 1941). Quanto a esse respeito, as gramineas parecem ser mais eficientes que as leguminosas.

Algumas vantagens da utilização de plantas de outtas famílias como adubos verdes, além das leguminosas, relacionam-se à sua elevada eficiência no rompimento de camadas compactadas, sistema radicular finamente dividido e possivelmente mais eficiente na absorção de nutrientes em ambientes pobres (CINTRA \& MIELNICZUK, 
1983), elevada eficiência na reciclagem de fósforo (CLARKSON, 1985), maior estabilidade da cobertura morta, condição esta desejável em algumas situações (plantio direto), principalmente no caso das gramíneas cuja relação $\mathrm{C}: \mathrm{N}$ é mais elevada que a das leguminosas.

Visando avaliar o comportamento das leguminosas feijão de porco e soja perene, utilizadas como adubação verde complementar e/ou como alternativa à adubação mineral dos citros, MAGALHÃES (1994), conduziu um experimento no período de 1981 a 1990 no Estado da Bahia, onde testou as leguminosas só ou em combinação com P e K, além de um tratamento testemunha ( $\mathrm{s} /$ adubo) e outro com NPK, conclui que a competição com a planta cítrica foi evidênciada pela redução do diâmetro do tronco, altura das plantas, circunferência da copa, porcentagem de suco, altura, diâmetro e espessura da casca dos frutos. Características do solo como pH, CTC, saturação por bases, matéria orgânica e microporosidade foram aumentados, bem como, a acidez total e brix, não observando efeito significativo das espécies testadas sobre as variáveis estudadas.

COSTA et al. (1993), relata que trabalhos realizados no Rio Grande do Sul no período de 1983 a 1989, sobre sistemas de rotação de culturas comerciais com espécies de adubos verdes, em diferentes sistemas de preparo de solo, apontaram efeitos positivos de recuperação do solo, em termos de sua agregação e estruturação, bem como elevação dos teores de matéria orgânica e CTC do solo, principalmente nos sistemas de plantio direto e cultivo mínimo.

\subsection{Corte e incorporação dos adubos verdes}

A decomposição do material vegetal adicionado ao solo é um processo essencialmente biológico, sujeito portanto à interferência de inúmeros fatores. Cada fator como a temperatura, a pressão osmótica, a tensão superficial, a viscosidade, a radiação, o $\mathrm{pH}$ do solo, a quantidade e a qualidade dos nutrientes orgânicos disponíveis, bem como a atividade da água, apresentam, dependendo da espécie, um nível ótimo, que exercerá uma influência marcante no montante populacional dos organismos ou microroganismos 
(LYNCH, 1986). Em solos ácidos há predominância de fungos, enquanto os solos próximos da neutralidade as bactérias são mais numerosas. Em solos alagados o pequeno número de bactérias presentes é incapaz de atacar a lignina, favorecendo o acúmulo dos resíduoas orgânicos (TEDESCO, 1983).

GRANER \& GODOY JUNIOR (1967), sugere que o corte das leguminosas deve ser feito no início do florescimento, deixando-se as plantas cortadas no chão, para o início da decomposição da matéria orgânica. Dessa forma, o material verde serve como proteção ao solo contra a erosão, ação direta dos raios solares e contra o desenvolvimento das plantas invasoras. $\mathrm{Na}$ aração de preparo definitivo, processa-se então a sua incorporação ao solo.

A composição dos resíduos vegetais, exerce forte influência na decomposição dos resíduos. A relação $\mathrm{C}: \mathrm{N}$, bem como o teor de lignina, governam boa parte dos processos de decomposição, mineralização e disponibilidade de $\mathrm{N}$ para as culturas em sucessão (HEINZMAN, 1983). Essa relação é influenciada pelo tipo de material e idade da planta.

Segundo MIYASAKA et al. (1984), o compostos orgânicos encontrados nos tecidos vegetais como hidratos de carbono (açucares e amidos - 1 a $5 \%$, hemicelulose 10 a $28 \%$ e celulose - 20 a $50 \%$ ), gorduras, ceras e taninos ( 1 a $8 \%$ ), ligninas ( 10 a $30 \%$ ) e proteinas ( 1 a $15 \%$ ), são submetidos ao processo de decomposição, mas não se decompõem com a mesma velocidade. Os açucares, amidos e proteinas simples, são os que se decompõem mais facilmente, seguidos pela proteina bruta e hemicelulose. Compostos como a celulose, lignina e gorduras, são mais resistentes ao processo de decomposição.

De forma geral, quando os tecidos das plantas entram em íntimo contato com o solo, passam por três fases distintas e sucessivas de decomposição, a saber:

a) transformações químicas que se operam logo após a morte dos tecidos, ocasionando amarelecimento, secamento, etc. Nesta fase, há um primeiro ataque microbiano sobre os compostos facilmente fermentáveis, como os açucares, hemicelulose, amido e pectinas. Os microorganismos predominantes, quando o meio é ácido, são os fungos; quando o meio passa a ser menos ácido, isto é, acima de pH 5,5, predominam as bactérias; 
b) a seguir, ocorrem transformações mecânicas que consistem na fragmentação e incorporação ao solo dos resíduos orgânicos: por ácaros, minhocas, etc.;

c) finalmente, ocorrem as transformações biológicas, operadas por microorganismos, tais como os fungos. As excreções da microflora proporcionam compostos solúveis ou missíveis em água, e mais uma parte residual, que será de novo atacado pelos microorganismos.

Os compostos de fácil decomposição desaparecem rapidamente, por ação microbiana, produzindo, de início substâncias intermediárias e por fim, os produtos mais simples relacionados a seguir:

Carbono - $\mathrm{CO}_{2}, \mathrm{CO}_{3}^{-2}, \mathrm{HCO}_{3}^{-}, \mathrm{CH}_{4}$ e carbono elementar;

Nitrogênio - $\mathrm{NH}_{4}^{+}, \mathrm{NO}_{2}^{-}, \mathrm{NO}_{3}^{-}$e $\mathrm{N}$ gasoso;

Enxofre - $\mathrm{S}, \mathrm{H}_{2} \mathrm{~S}, \mathrm{SO}_{3}^{-2}, \mathrm{SO}_{4}^{-2}$ e $\mathrm{CS}_{2}$;

Fósforo $-\mathrm{H}_{2} \mathrm{PO}_{4}^{-}$e $\mathrm{HPO}_{4}^{-2}$;

Outros $-\mathrm{H}_{2} \mathrm{O}, \mathrm{O}_{2}, \mathrm{H}_{2}, \mathrm{H}^{+}, \mathrm{OH}, \mathrm{Ca}^{2+}, \mathrm{Mg}^{2+}, \mathrm{K}^{+}$, etc.

Compostos como óleos, gorduras, resinas e especialmente a lignina, são mais resistentes e tendem a persistir. Estes compostos complexos, provenientes de materiais mais resistentes à decomposição, dão origem à substância que se denomina humus.

A permanência da cobertura morta depende muito da velocidade de decomposição dos resíduos, isto é, quanto mais rápido os resíduos vegetais se decompõem, menos protegem o solo. A decomposição, está inversamente relacionada ao teor de lignina e à relação C:N (COSTA, 1993). Assim, se o material em decomposição apresentar pouco $\mathrm{N}$ (alta relação $\mathrm{C}: \mathrm{N}$ ), este provavelmente será o fator limitante ao crescimento da população microbiana que, em média, apresenta $\mathrm{C}: \mathrm{N}$ igual a 10.

CAMARGO \& HERMANN (1928), estudaram a produção da parte aérea e das raizes de leguminosas e concluiram que as raízes do adubo verde dão resultados quase tão bons quanto, aqueles em que se incorpora toda a planta. As raízes decompoemse mais lentamente devido à sua composição, devendo o material orgânico incorporado ao solo conter no mínimo $1,5 \%$ de nitrogênio, pois caso contrário, toda a amônia liberada no período de transformação será utilizada pelos microorganismos que atuam na sua decomposição (NEME, 1959). 
Segundo POLLI \& CHADA (1989), é conveniente realizar a incorporação da vegetação de entrêssafra ao solo, ao invés de deixa-la na superfície, principalmente no caso das plantas mais fibrosas. Notaram também que há uma certa relação entre plantas mais tenras e o maior teor de $\mathrm{N}$ na parte aérea.

Os adubos verdes devem ser incorporados ao solo, de preferência, após o florescimento e antes da frutificação, para garantir a adição de uma grande quantidade de material vegetal. A incorporação das plantas, após o desenvolvimento dos frutos, vai resultar no uso de um material mais pobre e possível infestação dos solos com as sementes do adubo verde (COSTA, 1989).

Resíduos com uma relação C:N elevada $(>25)$ formam uma cobertura morta estável, que melhor contribui para a estruturação do solo e a proteção da superficie do impacto da chuva e radiação solar. Para este tipo de solo recomenda-se o uso de leguminosas em sucessão, pois favorece ao desenvolvimento do sistema radicular, à formação de nódulos nas raízes e portanto à fixação simbiótica de nitrogênio. Em resíduos com uma relação $\mathrm{C}: \mathrm{N}$ baixa $(<25)$, a mineralização é mais rápida, mesmo sem a sua incorporação ao solo. Acredita-se que valores entre 23 e 24 para a relação $\mathrm{C}: \mathrm{N}$ favoreçam a mineralização uniforme do nitrogênio, com reflexos positivos sobre o suprimento desse nutriente as espécies não leguminosas em sucessão (DERPSH et al, 1985; HEINZMANN, 1983; TEIXEIRA, 1988).

Estima-se que 2/3 do carbono orgânico incorporado ao solo é perdido para a atmosfera em clima temperado e, possivelmente, em condições tropicais as perdas sejam maiores. O montante que permanece no solo, cerca de $35 \%$, é assimilado pelos organismos heterotróficos.

Segundo MALAVOLTA (1976), quando são adicionados resíduos orgânicos ao solo, poderão ocorrer duas situações:

- resíduos com relação $\mathrm{C}: \mathrm{N}$ alta (pouco $\mathrm{N}$ ) resultam em perda elevada de $\mathrm{C}$ como $\mathrm{CO}_{2}$, na pouca formação de húmus e em deficiência de $\mathrm{N}$ para os cultivos posteriores;

- resíduos com relação $\mathrm{C}: \mathrm{N}$ baixa resultam em incremento na produção de húmus e na disponibilidade de $\mathrm{N}$ para as culturas posteriores. 
O processo de mineralização consiste na conversão do nitrogênio orgânico em mineral. A importância desse processo é que nos sistemas terrestes o nitrogênio encontra-se predominantemente na forma orgânica, onde os microorganismos realizam a maior parte da mineralização. A forma final do nitrogênio disponivel (nitrato), poderá ser absorvida pelas plantas, utilizadas pelos microorganismos (imobilização temporária) ou perdida no perfil do solo por lixiviação. Além dos microorganismos do solo, também a meso e a macrofauna exercem importante contribuição na decomposição dos resíduos, influenciando diretamente as características do solo. A macrofauna é representada principalmente pelas minhocas, os besouros, os cupins, as formigas, as lesmas, etc. Esses organismos atuam na desintegração dos resíduos e/ou alteram fisicamente o solo, através da construção de canais ou orificios, que promovem a infiltração de água no perfil.

MIYASAKA et al. (1984), afirmaram que o uso de adubos verdes resulta em: - economia em relação a carpa e aplicação de herbicida, devido a alta capacidade de competição das leguminosas em relação às plantas daninhas, levando a menor produção de sementes por parte destas;

- economia de adubos químicos e calcário, em virtude do seu melhor aproveitamento; - melhoria na produtividade e qualidade dos produtos colhidos, obtendo-se assim maiores lucros;

- diminuição dos efeitos provocados pela erosão, auxiliando o seu combate;

- proteção dos solos contra os efeitos dos ráios solares, assegurando melhor absorção e retenção de água, diminuindo os efeitos de seca;

- mobilização e transporte dos elementos nutritivos das camadas profundas do solo para a superficie;

- melhoria das condições físicas e biológicas do solo;

- melhoria na produtividade de algodão, soja, milho e de outras culturas, em solos infestados por nematóides, em percentuais de 30 a $80 \%$, sem a necessidade do uso de nematicidas. 


\section{MATERIAL E MÉTODOS}

O experimento foi instalado e conduzido na Estação Experimental de Citricultura de Bebedouro (E.E.C.B.), município de Bebedouro, Estado de São Paulo, (latitude 20 53' $16^{\prime \prime} \mathrm{S}$, longitude $48^{\circ} 28^{\prime} 11^{\prime \prime} \mathrm{W}$ e altitude de $601 \mathrm{~m}$ ).

\subsection{Características de solo e clima}

O solo é classificado segundo ANDRIOLI et al. (1994), como Latossolo Vermelho Escuro, epieutrófico, endoálico, A moderado, textura média, (Haplustox).

Na Tabela 1, é apresentado os resultados das análises de amostras de solo representativas da área para fins de fertilidade, coletadas antes da instalação do experimento em 1989, nas profundidades de $0-20$ e $21-40 \mathrm{~cm}$.

TABELA 1. Resultados das análises químicas das amostras de solo representativas da área onde foi implantado o experimento, em novembro de 1989

\begin{tabular}{|c|c|c|c|c|c|c|c|c|c|c|}
\hline \multirow{2}{*}{$\begin{array}{c}\text { Profund } \\
\mathrm{cm}\end{array}$} & \multirow{2}{*}{$\begin{array}{c}\mathrm{pH} \\
\mathrm{CaCl}_{2}\end{array}$} & \multirow{2}{*}{$\begin{array}{l}\text { M.O. } \\
\text { g/dm }\end{array}$} & \multirow{2}{*}{$\begin{array}{c}P \\
\mathrm{mg} / \mathrm{dm}^{3}\end{array}$} & $\mathrm{~K}$ & $\mathrm{Ca}$ & $\mathrm{Mg}$ & $\frac{\mathrm{H}+\mathrm{Al}}{3}$ & SB & $T$ & \multirow{2}{*}{$\begin{array}{l}\mathrm{V} \\
\% \\
\end{array}$} \\
\hline & & & & \multicolumn{6}{|c|}{$\mathrm{mmol}_{\mathrm{d}} / \mathrm{dm}^{3}$} & \\
\hline $0-20$ & 4,6 & 30 & 5 & 1,2 & 10,8 & 6,1 & 38 & 18,1 & 5,61 & 32 \\
\hline $21-40$ & 4,0 & 26 & 3 & 0,7 & 5,6 & 3,1 & 47 & 9,4 & 5,64 & 17 \\
\hline
\end{tabular}


O clima do local é caracterizado como Cwa (sub-tropical com inverno moderado e seco, verão quente e chuvoso) com temperatura média máxima de $28,8^{\circ} \mathrm{C}$, média mínima $18,3{ }^{\circ} \mathrm{C}$ e temperatura média de $23,5^{\circ} \mathrm{C}$; precipitação média anual de $1.522 \mathrm{~mm}$.

\subsection{Características do pomar}

O plantio do pomar foi realizado em maio de 1987 , com espaçamento de $7,0 \mathrm{~m}$ entre linhas e 5,0 m entre plantas, utilizando-se nas covas de plantio $400 \mathrm{~g}$ superfosfato simples, $1 \mathrm{~kg}$ calcário dolomítico e $10 \mathrm{~g}$ de sulfato de zinco.

Utilizou-se como copa a variedade de laranjeira 'Pera' (Citrus sinensis L. Osbeck), e como porta-enxerto a tangerineira 'Cleópatra' ( Citrus reshi Hort.).

\subsection{Características das leguminosas utilizadas}

As leguminosas utilizadas no experimento foram a Crotalaria juncea, Crotalaria spectabilis, guandú, mucuna preta, mucuna anã, labe labe e feijão de porco. As principais características destas espécies são descritas a seguir:

\section{- Crotalaria juncea:}

Nome científico: Crotalaria juncea $\mathrm{L}$.

Familia: Leguminosae; subfamília: Papilionoideae; tribo: Genisteae

Nome comum: Crotalaria juncea

Origem: Índia, Ásia tropical, Rússia Meridional

Descrição morfológica: Leguminosa anual de porte ereto, subarbustiva, podendo alcançar mais de três metros de altura. Caule semilenhoso e ramificado na parte superior, com talos estriados. Folhas unifoliadas, com pecíolo quase nulo, sésseis, elipticas, lanceolada e mucronadas, com nervura principal pronunciada. Flores de 2 a $3 \mathrm{~cm}$ de 
comprimento ( 15 a 50 por inflorescência). Vagens longas, pubescentes, com 10 a 20 grãos de coloração verde-acinzentada, reniformes, de face lisa.

Características agronômicas: Leguminosa anual, de crescimento rápido, com efeito alelopático e/ou supressor de invasoras bastante expressivo, comportando-se bem em solos arenosos e argilosos e não suporta geada. Muito empregada em áreas canavieiras com problemas de nematóides apresentando êxito na diminuição das populações destes. Do caule se extrai fibra para a indústria de papel. Quando é semeado no mesmo terreno por vários anos seguidos, pode surgir a moléstia denominada "murcha", que em certa escala, pode afetar o desenvolvimento das plantas. Áreas destinadas à produção de sementes devem ser semeadas de preferência, em fins de novembro. Deve ser incorporada após o floração ( 110 a 140 dias) e a produção de sementes pode ser calculada na base de 600 a $1000 \mathrm{~kg} / \mathrm{ha}$.

Vantagens e limitações: Crescimento rápido proporcionando boa cobertura do solo, tendo um importante efeito supressor e/ou alelopático às invasoras. Produção elevada de fitomassa e adapta-se bem a diferentes regiões. Quando cultivada por muito tempo no mesmo local, podem surgir problemas fitossanitários como Fusarium sp., bem como, ventos fortes poderão causar tombamento.

\section{- Crotalaria spectabilis}

Nome científico: Crotalaria spectabilis Roth.

Família: Leguminosae; subfamilia: Papilionoideae; tribo: Genisteae

Nome comum: Crotalaria spectabilis, guizo-de-cascavel, chocalho-de-cascavel

Origem: Brasil, América do Sul e do Norte

Descrição morfológica: Leguminosa subarbustiva, de porte alto $(1,0$ a $1,50 \mathrm{~m})$, ramificada, glabra, folhas simples, mucronadas no ápice, glabas na face superior e pubescentes na inferior, com 6 a $12 \mathrm{~cm}$ de comprimento e 2 a $4 \mathrm{~cm}$ de largura. Inflorescência terminal, em racemos de 20 a $30 \mathrm{~cm}$ de comprimento. 
Características agronômicas: Leguminosa anual que apresenta dificuldade na germinação, crescimento inicial lento, raiz pivotante profunda, podendo romper camadas compactadas e controladora de algumas espécies de nematóides. De clima tropical e subtropical, não suportando geadas. Bom comportamento em solos argilosos e arenosos. Plantio convencional de setembro a dezembro, de fácil incorporação após o florescimento aos 120-140 dias e possui flores com coloração amarela.

Vantagens e limitações: É bastante efetiva no controle de populações de nematóides, porém uma das limitações é a produção de sementes, pois sofre ataque de lagartas nas inflorescência e necessita do besouro mamangava para sucesso na polinização. A ingestão por animais de $3 \mathrm{~g}$ por $\mathrm{kg}$ de peso vivo pode levar à morte em 4 dias (LORENZI, 1984). A C. spectabilis pode ser utilizada como planta atrativa de lagartas em cultivos consorciados com citros.

\section{- Guandu}

Nome científico: Cajamus cajan (L.) Millsp

Família: Leguminosae; subfamilia: Papilionoideae; tribo: Phaseoleae

Nome comum: Guandu, guando, andu, sacha-café, falso café, arveja

Origem: Índia e África Tropical Ocidental

Descrição morfológica: Leguminosa arbustiva com folhas alternas trifoliadas; foliolos largos e ovais, coloração verde escura; inflorescência em racemos menores que as folhas, formando panículas sobre pedúnculos erguidos; flores amarelas ou amarelas com estrias avermelhadas ou roxas. Vagens de coloração castanha, verde, verde com estrias castanhas e com 4 a 7 sementes com coloração variável, predominando o marrom.

Características agronômicas: Planta anual, bianual ou semiperene, atingindo de 2 a 3 anos quando podada, cresce bem em solos argilosos e arenosos, com bastante tolerância à seca e não tolera umidade excessiva nas raizes. Planta rústica, pouco exigente em fertilidade que pode ser utilizada como adubação verde, produção de grãos e forrageira rica em proteinas para a alimentação animal. Semeadura convencional de setembro a 
dezembro. O manejo para adubação verde deve ser feito aos 140 a 180 dias e para a alimentação animal as melhores produções são obtidas quando a planta é colhida aos 30 dias com corte de 40 a $60 \mathrm{~cm}$ acima do solo.

Vantagens e limitações: Fixa elevada quantidade de nitrogênio e produz bastante fitomassa. Pode ser utilizado como adubação verde; em rotação e associações de cultivos; em consorciação com gramíneas anuais; em cultivo intercalar a culturas perenes; como fonte de proteina; na alimentação animal com 16 a $23 \%$ de proteina bruta na fase de florescimento (pastejo, corte, silagem, feno); produção de grãos (alimentação animal, humana e comercialização). Sistema radicular capaz de reciclar grande quantidades de nutrientes no solo, sistema radicular pivotante, bastante agressivo que penetra em solos compactados e adensados. Embora semi-perene, deve ser cultivada por um ou no máximo 2 anos, porque, por mais tempo, os troncos engrossam e se tornam muito lenhosos, dificultando o enterrio do material para adubação verde.

\section{- Mucuna preta}

Nome científico: Stizolobium aterrimum $=$ Mucuna aterrima

Familia: Leguminosae; subfamilia: Papilionoideae; tribo: Phaseoleae

Nome comum: Mucuna preta

Origem: Sudeste da Ásia

Descrição morfológica: Leguminosa robusta, de crescimento rasteiro e indeterminado, ramos trepadores, folhas trifoliadas, de folíolos longos e membranosos; inflorescência em racemos axilares, composta por muitas flores violáceas, grandes e brácteas caducas, vagem alargada, com 3 a 6 sementes, globosas e elípticas, de coloração preta, com hilo branco, deiscentes após a completa maturação.

Características agronômicas: Planta anual bastante rústica, resistente à seca, à sombra, às temperaturas elevadas e ligeiramente resistente ao encharcamento, desenvolvendo-se bem em solos pobres. Semeadura convencional, de setembro a início de janeiro e o manejo se faz após o florescimentos aos 140 a 170 dias. 
Vantagens e limitações: Além do uso como adubo verde, é empregada como forrageira ou seus grãos aproveitados como suplemento protéico para animais. Uma das limitações é a suscetibilidade que possui à cercosporiose a às viroses. Atua no impedimento da multiplicação de nematóides.

\section{- Mucuna anã}

Nome científico: Mucuna deeringiana $($ sin. Stizolobium deeringianum $)$ Steph e Bart = Mucuna pruriens

Familia: Leguminosae; subfamília: Papilionoideae; tribo: Phaseoleae

Nome comum: Mucuna anã, mucuna enana

Origem: Sudeste da Ásia

Descrição morfológica: Leguminosa herbácea, ereta, com folhas trifoliadas, de folíolos grandes, membranosos, inflorescência em racemos, composto por inúmeras flores de coloração violácea; vagens de 5 a $8 \mathrm{~cm}$ de comprimento revestidas de pelos curtos e abundantes; sementes arredondadas de coloração rajada, marrom-preto, sobre fundo branco, com hilo branco pouco saliente.

Características agronômicas: Planta anual, de crescimento determinado, com altura em torno de 40 a $80 \mathrm{~cm}$, resistente à seca, desenvolve-se bem em solos argilosos e arenosos e de baixa fertilidade. Semeadura no sistema convencional, de setembro a janeiro. $O$ manejo deve ser realizado no florescimento ao início do enchimento de vagens ( 80 a 100 dias).

Vantagens e limitações: Adubo verde bastante recomendado para plantio intercalar, em função do hábito determinado e não trepador, porém com menor fitomassa que a mucuna cinza e preta. A semeadura deve ser efetuada de tal forma que o manejo da mucuna-anã coincida com a época de maior demanda de nitrogênio pela cultura principal. Em algumas regiões tem sido verificado certa suscetibilidade da mucuna-anã à cercosporiose, mas não a ponto de inviabilizar seu cultivo. Não tem apresentado problema de pragas. 


\section{- Labe labe}

Nome científico: Dolichos lablab L.; Lablab vulgaris Savi

Familia: Leguminosae; subfamília: Papilionoideae; tribo: Phaseoleae

Nome comum: Labe labe, poroto do egito, poroto japonês

Origem: África

Descrição morfológica: Leguminosa de talos bastante longos, trepadores e cilindricos; folhas compostas de 3 folíolos, com estípulas pequenas e pontiagudas; as flores apresentam-se em racemos axilares pedunculados e de cor branca, rosada ou violácea, com 1,5 a $2,0 \mathrm{~cm}$. Frutos em vagens pequenas, lineares com ponta recurvada, curtas ou ovais, hilo bastante saliente, de forma oblonga, cor branca e ocupando $1 / 3$ do perímetro da semente.

Características agronômicas: Planta anual ou bianual, hábito indeterminado. Adapta-se a solos argilosos a arenosos, com melhor performance naqueles bem drenados e férteis, tolerante à seca. Usada na alimentação humana e forragem verde para bovinos e eqüinos. Semeadura em sistema convencional, de setembro a dezembro. É suscetivel ao ataque de vaquinha (Cerotoma sp, Diabrotica speciosa). O manejo recomendado é no florescimento-início da formação de vagens ( 130 a 180 dias).

Vantagens e limitações: Planta com resistência a geadas, podendo ser utilizada para ensilagem, juntamente com milho ou sorgo. Tem sido observado que o labe labe além de não apresentar nodulação, tem ainda o incoveniente de ser multiplicador das populações de nematóides. Quando utilizada em excesso como forrageira além de provocar o timpanismo, transmite um gosto amargo ao leite. 


\section{- Feiião de porco}

Nome científico: Canavalia ensiformis (L.) DC.

Família: Leguminosae; subfamilia: Papilionoideae; tribo: Phaseoleae

Nome comum: Feijão de porco, poroto sable, poroto gigante

Origem: Centro-americana

Descrição morfológica: Leguminosa de crescimento ereto e de hábito determinado (60 a $120 \mathrm{~cm}$ de altura). Folhas alternas, trifoliadas, folíolos grandes elípticos-ovais, de cor verde-escura brilhante, com nervuras bem salientes; inflorescência axilares em racemos grandes; flores grandes, corola de cor violácea ou roxa, vagem achatada, larga e comprida ( $25 \mathrm{~cm}$ ou mais), coreácea, contendo 4 a 18 sementes grandes, de forma arredondado-ovalada, de cor branca ou rosada; hilo oblongo de cor parda, rodeado de uma zona de cor castanha, com lingueta de cor branca.

Características agronômicas: Planta anual ou bianual, herbácea, rústica, crescimento inicial lento, resistente a altas temperaturas e à seca. Tolera sombreamento parcial e geada. Adapta-se a diferentes tipos de solo inclusive solos pobres. Preparo do solo no sistema convencional de setembro a dezembro. Esporadicamente sofre ataque de vaquinha (Diabrotica speciosa), tem convivência sem maiores problemas, com a presença de viroses, é hospedeiro da mosca branca (Bemisia tabaci), transmissora do VMDF (vírus do mosaico dourado do feijoeiro) e de outras viroses do feijoeiro comum. $\mathrm{O}$ manejo deve ser feito no florescimento/início da formação de vagens (100 a 120 dias).

Vantagens e limitações: Planta que cobre bem o solo, com efeito alelopático às invasoras, atuando eficientemente no controle da tiririca (Cyperus sp). Uma das limitações é o avantajado tamanho das sementes, o que leva a um gasto elevado na implantação da cultura. 


\subsection{Delineamento experimental e tratamentos}

O delineamento experimental adotado foi o de blocos inteiramente casualizados, com nove tratamentos sendo dois sem leguminosas e sete com as leguminosas. A diferença entre os dois tratamentos sem leguminosas é a dose de nitrogênio na adubação química das plantas cítricas, pois o tratamento 1 , recebeu a adubação NPK técnicamente recomendada para a área (citros), enquanto que o tratamento 2, recebeu o dobro da dose de $\mathrm{N}$ do tratamento 1 , ou seja, $2 \mathrm{~N}, \mathrm{P}, \mathrm{K}$. Utilizou-se quatro repetições, totalizando 36 parcelas, sendo cada parcela constituída por cinco plantas, num total de 180 plantas.

Os resultados das avaliações no período de quatro anos de plantio, foram analisados de acordo com o delineamento em parcelas subdivididas, considerando-se os anos como sub-parcelas.

As análises de variância foram realizadas pelo "teste $F$ " e os valores médios comparados pelo "teste de Tukey" ao nível de $5 \%$ de probabilidade, conforme BANZATTO \& KRONKA (1989).

Na Tabela 2, são apresentados os tratamentos utilizados.

TABELA 2. Tratamentos utilizados

\begin{tabular}{cl}
\hline Tratamentos & Descrição \\
\hline 1 & adubação $\mathrm{N}, \mathrm{P}$ e K - sem leguminosas intercalar ao citros (mas c/ mato) \\
2 & adubação $2 \mathrm{~N}, \mathrm{P}$ e K - sem leguminosas intercalar ao citros (mas c/ mato) \\
3 & adubação P e K + plantio intercalar de Crotalaria juncea \\
4 & adubação P e K + plantio intercalar de Crotalaria spectabilis \\
5 & adubação P e K + plantio intercalar de Cajamus cajan - guandú \\
6 & adubação P e K + plantio intercalar de Mucuna aterrima - mucuna preta \\
7 & adubação P e K + plantio intercalar de Mucuna deeringiana -mucuna anã \\
8 & adubação P e K + plantio intercalar de Dolichos labe-labe - labe labe \\
9 & ad. P e K + plantio intercalar Canavalia ensiformis - feijão de porco
\end{tabular}

$\mathrm{N}=$ nitrogênio, $\mathrm{P}=$ fósforo e $\mathrm{K}=$ =potássio; nas doses recomendadas para citros (GRUPO PAULISTA, 1988) 


\subsection{Instalação do experimento}

A primeira semeadura deu-se no dia 20-12-89; a $2^{\mathrm{a}}$ semeadura no dia 14-1190 ; a $3^{a}$ semeadura deu-se no dia 10-12-91 e a $4^{a}$ semeadura no dia 23-12-92.

Antes do preparo do solo para semeadura, efetuou-se a aplicação de herbicida em faixa na projeção da copa dos citros, bem como, a inspeção do pomar para tratamento fitossanitário com acaricidas e inseticidas. A semeadura foi precedida de uma gradagem leve nas entrelinhas das parcelas (mesmo nas testemunhas), seguido de sulcação rasa e semeadura manual, procedimentos iguais para todos os tratamentos com leguminosas. Cada parcela constou de cinco plantas cítricas espaçadas de cinco metros. Nas entrelinhas realizou-se a semeadura de sete linhas de leguminosas de cada lado das plantas cítricas a serem avaliadas, sendo que a primeira linha de leguminosas ficou a dois metros da linha de citros.

A Figura 1, ilustra o esquema de campo.

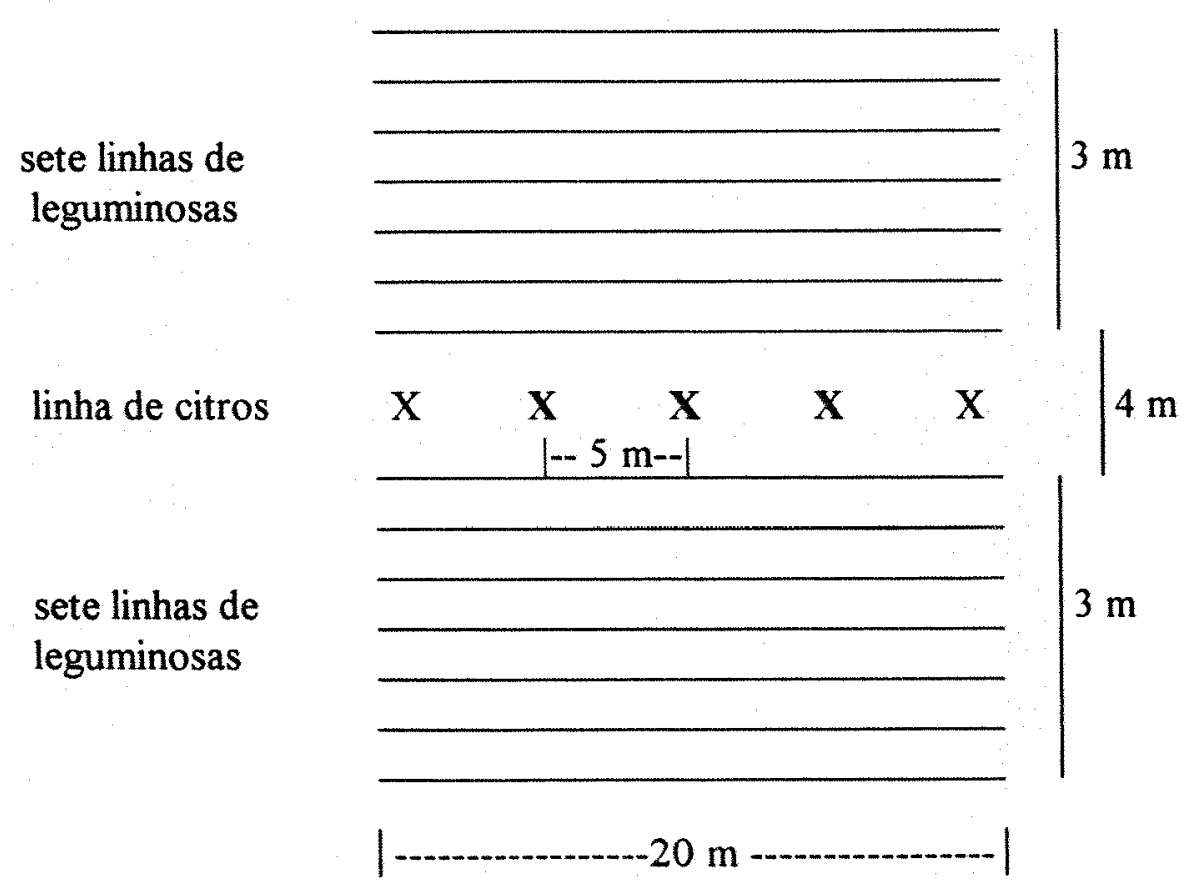

FIGURA 1. Croquí da parcela experimental de citros com linhas de adubos verdes nas entrelinhas 
As três plantas de citros centrais foram utilizadas nas avaliações de desenvolvimento do pomar, ficando as outras duas como bordadura. Não se utilizou adubação de plantio nos adubos verdes (tratamentos de 3 a 9), inoculação nas sementes, cultivadores e herbicidas nas entrelinhas. A semeadura dos adubos verdes seguiu a recomendação abaixo, como ilustra a Tabela 3.

TABELA 3. Densidade de sementes e espaçamento utilizado na semeadura

\begin{tabular}{lccc}
\hline Espécies & $\begin{array}{c}\text { Sementes } \\
(\mathrm{kg} / \mathrm{ha})\end{array}$ & $\begin{array}{c}\text { Densidade } \\
(\mathrm{sem} . / \mathrm{m} . \text { linear })\end{array}$ & $\begin{array}{c}\text { Espaçamento } \\
(\mathrm{m})\end{array}$ \\
\hline Crotalaria juncea & 30 & 25 & 0,5 \\
Crotalaria spectabilis & 15 & 38 & 0,5 \\
Guandu & 50 & 17 & 0,5 \\
Mucuna Preta & 85 & 5 & 0,5 \\
Mucuna Anã & 105 & 10 & 0,5 \\
Labe-labe & 60 & 13 & 0,5 \\
Feijão de Porco & 100 & 5 & 0,5 \\
\hline
\end{tabular}

Obs: As recomendações são baseadas no peso de 1.000 sementes e adaptadas para cultivo intercalar à cultura de citros; (*) Espaçamento entre as linhas de leguminosas

\subsection{Calagem}

Antes do preparo do solo para a instalação do experimento, foi efetuada em setembro de 1989 e 1992, calagem na área experimental, aplicando-se 2,0 t/ha de calcário dolomítico, para fins de elevar a saturação por bases para $65 \%$.

\subsection{Tratos culturais dos citros}

Os tratos culturais foram realizados de acordo com as recomendações usuais e 
necessidades, ou seja , aplicações de fungicidas, acaricidas, inseticidas, além de herbicidas e capinas manuais nas linhas de citros, podas de limpeza, desbrota e controle de formigas.

\subsection{Adubação de manutenção dos citros $\left(\mathrm{N}, \mathrm{P}_{2} \mathrm{O}_{5}, \mathrm{~K}_{2} \mathrm{O}\right)$}

A adubação de manutenção dos citros foi efetuada manualmente, na projeção da copa, de acordo com a recomendação do GRUPO PAULISTA (1988), parcelando a dose em três aplicações no período de setembro a fevereiro, nas quantidades como ilustra a Tabela 4.

TABELA 4. Quantidade de adubo aplicado no citros nos quatro anos agrícolas

\begin{tabular}{|c|c|c|c|c|c|}
\hline Tratamento & Fonte adubo & $\begin{array}{l}\text { g/planta } \\
1989 / 90\end{array}$ & $\begin{array}{l}\text { g/planta } \\
1990 / 91\end{array}$ & $\begin{array}{l}\text { g/planta } \\
1991 / 92\end{array}$ & $\begin{array}{l}\text { g/planta } \\
1992 / 93\end{array}$ \\
\hline \multirow{6}{*}{ T 1} & Uréia & 600 & 800 & 800 & 1,000 \\
\hline & SPT & 530 & 710 & - & - \\
\hline & $\mathrm{KCl}$ & 300 & 400 & - & - \\
\hline & $00-15-10$ & - & 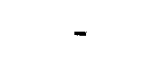 & 2,500 & 3,000 \\
\hline & F.T.E * & 60 & 80 & - & - \\
\hline & Total & 1,490 & 1,990 & 3,300 & 4,000 \\
\hline \multirow{6}{*}{$\mathrm{T} 2$} & Uréia & 1,200 & 1,600 & 1,600 & 2,000 \\
\hline & SPT & 530 & 710 & - & - \\
\hline & $\mathrm{KCl}$ & 300 & 400 & - & - \\
\hline & $00-15-10$ & - & - & 2,500 & 3,000 \\
\hline & F.T.E * & 60 & 80 & - & - \\
\hline & Total & 2,090 & 2,790 & 4,100 & 5,000 \\
\hline \multirow{6}{*}{ T 3 a T 9} & Uréia & - & - & - & - \\
\hline & SPT & 530 & 710 & - & - \\
\hline & $\mathrm{KCl}$ & 300 & 400 & - & - \\
\hline & $00-15-10$ & - & - & 2,500 & 3,000 \\
\hline & F.T.E. * & 60 & 80 & - & - \\
\hline & Total & 890 & 1,190 & 2,500 & 3,000 \\
\hline
\end{tabular}

F.T.E. $=$ Oxido Silicatado $\left(24 \% \mathrm{Zn}, 4 \% \mathrm{Mn}\right.$ e $2 \%$ B); Uréia $=45 \% \mathrm{~N} ; \mathrm{SPS}=20 \% \mathrm{P}_{2} \mathrm{O}_{5} ; \mathrm{KCl}=60 \%$ $\mathrm{K}_{2} \mathrm{O}$ 
Além dos adubos químicos aplicados no solo, todas as plantas cítricas receberam adubação de micronutrientes, via foliar, conforme recomendação do GRUPO PAULISTA (1988).

\subsection{Densidade populacional dos adubos verdes}

Objetivando avaliar a densidade populacional dos adubos verdes, após trinta dias da semeadura, efetuou-se a contagem das plantas sobreviventes nas linhas de semeadura das parcelas, dos dois lados das plantas de citros. Desta contagem obteve-se a porcentagem de plantas sobreviventes em relação a semeadura.

\subsection{Diagnose foliar das plantas de citros}

O estado nutricional das plantas, foi avaliado através de análise foliar realizada 40 dias após a ultima adubação, ou seja, nos meses de março a abril de cada ano agrícola.

Foram coletadas a $3^{\mathrm{a}}$ e $4^{\mathrm{a}}$ folhas a partir do fruto, de ramos frutíferos, geradas na primavera, em número de oito folhas por planta da área útil das parcelas, uma em cada quadrante (de cada planta) e na altura mediana da copa (GRUPO PAULISTA, 1988; VITTI, 1988), totalizado 24 folhas formando assim uma amostra composta por parcela. As amostras, devidamente etiquetadas foram enviadas ao laboratório, onde foram lavadas com detergente neutro, enxaguadas, passadas em solução de ácido clorídrico e água destilada, enxaguada novamente em água destilada, empacotada em saco de papel perfurado e secas em estufa de circulação forçada de ar à $70^{\circ} \mathrm{C}$. Após a secagem, foram moídas e enviadas ao laboratório do Departamento de Ciência do Solo da ESALQ-USP, para a determinacão dos teores dos macronutrientes $\mathrm{N}, \mathrm{P}, \mathrm{K}, \mathrm{Ca}, \mathrm{Mg}$ e $\mathrm{S}$ e dos micronutrientes $\mathrm{B}, \mathrm{Cu}, \mathrm{Fe}, \mathrm{Mn}, \mathrm{Zn}$ e $\mathrm{Na}$, conforme metodologia descrita por MALAVOLTA et al. (1989). 
A interpretação dos resultados da análise química foi efetuada comparando os teores encontrados com as faixas para interpretação de teores de macro e micronutrientes nas folhas de citros propostas pelo GRUPO PAULISTA (1994) e que estão listadas na Tabela 5.

TABELA 5. Faixa para interpretação de teores de macro e de micronutrientes nas folhas de citros, geradas na primavera, com seis meses de idade, de ramos com frutos

\begin{tabular}{cccc}
\hline Macronutrientes & Baixo & Adequado & Excessivo \\
\cline { 2 - 4 } & & $\mathrm{g} / \mathrm{kg}$ & $>30$ \\
$\mathrm{~N}$ & $<23$ & $23-27$ & $>2,0$ \\
$\mathrm{P}$ & $<1,2$ & $1,2-1,6$ & $>20$ \\
$\mathrm{~K}$ & $<10$ & $10-15$ & $>50$ \\
$\mathrm{Ca}$ & $<35$ & $35-45$ & $>5,0$ \\
$\mathrm{Mg}$ & $<2,5$ & $2,5-4,0$ & $>5,0$ \\
$\mathrm{~S}$ & $<2,0$ & $2,0-3,0$ & $>150$ \\
Micronutrientes & & $\mathrm{mg} / \mathrm{kg}$ & $>15,0$ \\
$\mathrm{~B}$ & $<36$ & $36-100$ & $>200$ \\
$\mathrm{Cu}$ & $<4,1$ & $4,1-10,0$ & $>100$ \\
$\mathrm{Fe}$ & $<50$ & $50-120$ & $>100$ \\
$\mathrm{Mn}$ & $<35$ & $35-50$ & $>2,00$ \\
$\mathrm{Zn}$ & $<35$ & $35-50$ & \\
$\mathrm{Mo}$ & $<0,10$ & $0,10-1,00$ & \\
\hline
\end{tabular}

Para a variedade de laranja Westin, os teores adequados de Cu sugeridos são $10-20 \mathrm{mg} / \mathrm{kg}$

\subsection{Desenvolvimento vegetativo das plantas de citros}

Com o objetivo de avaliar o desenvolvimento das plantas cítricas foram realizadas medições das plantas em cada ano nos meses de março. A altura e o diâmetro da copa foram medidos com uma régua métrica graduada em centímetros, sendo que para a 
altura das plantas cítricas, à partir do solo até o ápice da planta e o diâmetro da copa foi obtido da média de duas medidas, sendo uma no sentido da linha de citros e a outra perpendicular à linha de citros.

Com base nestas medidas o volume das copas foi calculado através da fórmula proposta por Mendel (1956), que admite que uma planta cítrica se assemelha a uma semielipsóide prolata (POMPEU JUNIOR, 1972).

$$
\mathrm{V}=2 / 3 \pi \cdot \mathrm{R}^{2} \cdot \mathrm{H}
$$

onde : $\mathrm{V}=$ volume de copa $\left(\mathrm{m}^{3}\right)$

$\mathrm{R}=$ raio médio $(\mathrm{m})$

$\mathrm{H}=$ altura da copa $(\mathrm{m})$

Foram medidos os diâmetros dos troncos $2,5 \mathrm{~cm}$ acima da linha de enxertia com auxilio de um paquímetro, sempre no sentido da linha de citros, conseguindo-se assim, no ano seguinte, medir o mesmo ponto do caule.

\subsection{Incidência de plantas daninhas}

Antes do corte e incorporacão das leguminosas, avaliou-se a incidência de plantas daninhas nas parcelas com leguminosas, bem como, a cobertura do solo pelas leguminosas. Com o auxilio de um quadro de madeira com área interna de um metro quadrado, efetuou-se a contagem de plantas daninhas, determinando assim a porcentagem média, tomando como $100 \%$ os tratamentos 1 e 2, onde não foi semeado as leguminosas. Além disso, foram identificadas em ordem decrescente, as espécies de invasoras com maior ocorrência em cada parcela. 


\subsection{Análise química do solo}

A amostragem do solo foi efetuada com o trado tipo sonda e analisadas segundo metodologia descrita por RAIJ \& QUAGGIO (1983).

Os resultados e a discussão foram interpretados segundo critérios descritos pelo GRUPO PAULISTA (1994), conforme Tabelas 6 e 7.

TABELA 6. Padrões de fertilidade para interpretação de resultados de análise de solo para citros

\begin{tabular}{ccccc}
\hline Classes de teores & $\begin{array}{c}\text { Fósforo } \\
\text { (resina) }\end{array}$ & Potássio & Magnésio & $\begin{array}{c}\text { Saturação } \\
\text { por bases }\end{array}$ \\
\hline $\mathrm{mg} / \mathrm{dm}^{3}$ & $\mathrm{mmol}_{\mathrm{d}} / \mathrm{dm}^{3}$ & $\mathrm{mmol}_{\mathrm{d}} \mathrm{dm}^{3}$ & $\%$ \\
\hline Muito baixo & $<6$ & $<0,8$ & - & $<26$ \\
Baixo & $6-12$ & $0,8-1,5$ & $<4$ & $26-50$ \\
Médio & $13-30$ & $1,6-3,0$ & $4-8$ & $51-70$ \\
Alto & $>30$ & $>3,0$ & $>8$ & $>70$ \\
\hline
\end{tabular}

Obs: Manter, no mínimo, $10 \%$ da CTC com $\mathrm{Mg}^{2+}$ e $40 \%$ com $\mathrm{Ca}^{2+}$

TABELA 7. Interpretação preliminar de resultados de análise de solo para enxofre e micronutrientes

\begin{tabular}{cccccc}
\hline Classes de teores & $\mathrm{S}^{-\mathrm{SO}_{4}}$ & Boro & Cobre & Mangânes & Zinco \\
\hline & \multicolumn{5}{c}{$\mathrm{mg} / \mathrm{dm}^{3}$} \\
Baixo & $<5$ & $<0,20$ & $<0,3$ & $<1,5$ & $<0,7$ \\
Médio & $5-10$ & $0,20-0,60$ & $0,3-1,0$ & $1,5-5,0$ & $0,7-1,5$ \\
Alto & $>10$ & $>0,60$ & $>1,0$ & $>5,0$ & $>1,5$ \\
\hline
\end{tabular}




\subsubsection{Análise química do solo na linha de citros}

A amostragem de solo na linha de citros, foi efetuada, anualmente, aos 40 dias após o ultimo parcelamento de adubação química (não foi efetuada no primeiro plantio 1989/90), na profundidade de $0-20 \mathrm{~cm}$ na linha dos citros (projeção da copa), nas três plantas centrais de cada parcela, dos dois lados de cada planta, formando uma amostra composta/parcela proveniente de seis sub-amostras. Essas amostras foram devidamente embaladas, identificadas e enviadas ao laboratório do Departamento de Ciência do Solo da ESALQ/USP, para serem análisadas químicamente. Os resultados destas análises, serviram de base para calcular a adubação do ano seguinte.

\subsubsection{Análise química do solo nas linhas das leguminosas}

A amostragem do solo nas linhas das leguminosas foi efetuada anualmente antes da semeadura, nas profundidades de $0-20$ e $20-40 \mathrm{~cm}$ em cada parcela, sendo uma amostra composta/parcela proveniente de seis sub-amostras. Essas amostras também foram embaladas, identificadas e enviadas ao laboratório, para serem análisadas químicamente.

\subsubsection{Análise química do solo após o corte das leguminosas}

Após o corte das leguminosas foram efetuadas anualmente três amostragens de solo, sendo a primeira no dia do corte, a segunda após 90 dias do corte e a terceira após 180 dias do corte, na profundidade de $0-20 \mathrm{~cm}$, com o auxílio da sonda amostradora de solo. Estas amostras foram colocadas em sacos plásticos próprios para análises, devidamente identificadas e enviadas ao laboratório, para serem análisadas químicamente. 


\subsection{Amostragem de fitomassa das leguminosas}

Um dia antes do corte e/ou incorporação, realizou-se a coleta de material verde (fitomassa). Com o auxílio de um quadro de madeira com área interna de $1 \mathrm{~m}^{2}$, colocado aleatóriamente na parcela com as leguminosas, efetuou-se o corte do material contido no interior do quadro. Coletou-se assim, duas amostras de $1 \mathrm{~m}^{2}$ cada, sendo ambas pesadas no proprio local para a determinação do material verde. Em seguida, uma das amostras foi devolvida ao local do corte, enquanto a outra foi embalada, etiquetada e enviada ao laboratório, onde foram secas em estufa, para determinação da porcentagem de umidade e peso seco do material.

Após estarem secas as amostras da parte aérea das leguminosas, foram moídas e analisadas quimicamente para determinação dos teores dos nutrientes $\mathrm{N}, \mathrm{P}, \mathrm{K}$, $\mathrm{Ca}, \mathrm{Mg}, \mathrm{S}, \mathrm{B}, \mathrm{Cu}, \mathrm{Fe}, \mathrm{Mn}$ e $\mathrm{Zn}$, segundo metodologia descrita por MALAVOLTA et al. (1989).

\subsection{Corte das leguminosas}

O corte das leguminosas deveria ocorrer por volta dos 110 dias após a semeadura, porém, no segundo ano o corte deu-se aos 148 dias, devido a ocorrência de chuvas no período.

A primeira semeadura deu-se no dia $11 / 04 / 90$, aos 113 dias após a semeadura; a segunda no dia 11/04/91, aos 148 dias após a semeadura; a terceira no dia 27/03/92, aos 107 dias após a semeadura e a quarta no dia 08/04/93, aos 106 dias após a semeadura.

Para o corte dos adubos verdes utilizou-se roçadeira acoplada ao trator, efetuando o corte das leguminosas rente ao solo, deixando uma camada de material na superficie de cada parcela e tomando o cuidado de não arrastar o material de uma parcela para outra. 


\subsection{Produção de frutos cítricos}

As colheitas de frutos citricos foram efetuadas nos anos agrícolas de 1990/91, 91/92 e 92/93. A colheita dos frutos e sua pesagem foram efetuadas por parcela, obtendo-se posteriormente a produção média em kg por planta de cada tratamento.

$\mathrm{O}$ índice de produtividade ou índice de eficiência produtiva de cada tratamento foi obtido dividindo-se a produção média de frutos cítricos $(\mathrm{kg} /$ planta) pelo seu respectivo volume de copa $\left(\mathrm{m}^{3}\right)$, obtendo assim a produção de frutos por unidade de volume de copa, com valores expressos em $\mathrm{kg} / \mathrm{m}^{3}$.

\subsection{Qualidade dos frutos cítricos}

A qualidade dos frutos foi avaliada por ocasião das colheitas, no laboratório da E.E.C.B., tendo por base amostras de 10 frutos por parcela, onde determinou-se:

a) altura e diâmetro - medidos com régua tipo calha, onde os 10 frutos de cada amostra foram colocados justapostos, sendo posteriormente calculada a média dos parâmetros;

b) peso - determinado por gravimetria em balança de 10 quilogramas de capacidade com subdivisões de 1 grama e calculado o peso médio por fruto;

c) rendimento em suco - foi calculado pela porcentagem do peso de suco da amostra, extraido em espremedor manual, em relação ao peso dos frutos da amostra. $\mathrm{O}$ peso de suco foi obtido por diferença entre o peso dos frutos e o peso do bagaço;

d) sólidos solúveis totais - determinado por refratometria a $20^{\circ} \mathrm{C}$ e expressos em graus Brix ( $\mathrm{g} / 100 \mathrm{ml}$ ) segundo métodos descrito por READ et al. (1986);

e) acidez titulável - determinada por titulometria com solução de hidróxido 0,3125 normal, e os resultados expressos em gramas de ácido cítrico por $100 \mathrm{ml}$ de suco de acordo com os métodos analíticos citados por READ et al. (1986);

f) índice de maturação ou "ratio" - obtido por cálculo, dividindo-se o teor de sólidos solúveis totais pela acidez titulável; 
g) índice tecnológico - expresso em $\mathrm{kg} /$ caixa e calculado pela equação proposta por Di Giorgi et al. (1990):

$\mathrm{IT}=\frac{\mathrm{SST} \cdot \mathrm{RS} \cdot 40,8}{10.000}$

onde,

$\mathrm{IT}=$ índice tecnológico

$\mathrm{SST}=$ sólidos solúveis totais $\left({ }^{\circ} \mathrm{Brix}\right)$

$\mathrm{RS}=$ rendimento em suco $(\%)$

$40,8=$ peso padrão industrial, em $\mathrm{kg}$ da caixa de citros . 


\section{RESULTADOS E DISCUSSÃo}

\subsection{Avaliação da densidade populacional}

Após 30 dias da semeadura das leguminosas, foram efetuadas a contagem das plantas nas linhas centrais de cada parcela, cujos dados encontram-se na Tabela 8.

TABELA 8. Densidade de semeadura utilizada e número médio de plantas sobreviventes por metro linear, médias obtidas nos quatro anos agrícolas.

\begin{tabular}{lccccccc}
\hline Tratamento & $\begin{array}{c}\text { Densidade } \\
\text { sem./m. 1. }\end{array}$ & $1989 / 90$ & $1990 / 91$ & $1991 / 92$ & $1992 / 93$ & Média & \% Média \\
& Sobreviv. \\
\hline C. juncea & 25 & 21,2 & 20,1 & 21,4 & 17,1 & 19,9 & 80 \\
C. spectabilis & 38 & 11,5 & 7,9 & 14,8 & 8,5 & 10,7 & 28 \\
Guandú & 17 & 14,4 & 14,0 & 14,6 & 10,4 & 13,3 & 78 \\
Mucuna preta & 5 & 4,5 & 4,4 & 4,5 & 4,2 & 4,4 & 87 \\
Mucuna anã & 10 & 8,6 & 8,5 & 9,3 & 4,9 & 7,8 & 78 \\
Labe labe & 13 & 8,4 & 6,8 & 9,8 & 8,2 & 8,3 & 64 \\
Feijão de porco & 5 & 4,9 & 4,9 & 4,7 & 4,4 & 4,7 & 94 \\
\hline Obs:
\end{tabular}

Obs: 1 - plantas/m.l. após 30 dias da semeadura

Observa-se que, determinadas espécies tiveram densidade populacional abaixo do ideal, influenciando no desenvolvimento, produção de fitomassa e competição com plantas daninhas. 
A Crotalaria spectabilis, apresentou estande abaixo do esperado, devido à característica da espécie de ter crescimento inicial lento, sofrendo, concorrência maior com as plantas daninhas infestantes nas parcelas e, possivelmente também a ocorrência de fungos nas sementes, influenciando na germinação e desenvolvimento das plântulas.

O labe labe, apresentou população um pouco abaixo do ideal, porém esta ocorrência não afetou a cobertura das parcelas, devido principalmente a característica da planta de crescimento indeterminado.

A mucuna anã, apresentou boa densidade populacional, porém foi posteriormente infectada pelo fungo da cercosporiose, provocando tombamento, queda de folhas e morte de algumas plantas.

As demais espécies apresentaram densidade populacional adequado, dentro dos números recomendados que são baseados no peso de 1.000 sementes, dominando a área das parcelas e superando a infestação de plantas daninhas.

\subsection{Determinação da altura das leguminosas}

$\mathrm{Na}$ Tabela 9, são apresentadas as médias da altura das leguminosas, resultante dos quatro anos de cultivo, bem como a altura do mato nas parcelas dos tratamentos 1 (NPK) e 2 (2NPK), onde não se plantou o adubo verde, e deixou-se estas plantas daninhas infestantes na área crescerem e serem roçadas na mesma época dos adubos verdes. Com o auxílio de régua graduada, efetuou-se a medição da altura das plantas em três pontos de cada parcela, obtendo-se assim um valor médio de altura. 
TABELA 9. Resultado da medição da altura das plantas nas parcelas intercalares ao citros nos anos agrícolas, 1989/90, 90/91, 91/92 e 92/93

\begin{tabular}{lccccc}
\hline Tratamento & \multicolumn{5}{c}{ Altura $(\mathrm{m})$} \\
\cline { 2 - 6 } & $1989 / 90$ & $1990 / 91$ & $1991 / 92$ & $1992 / 93$ & Média \\
\hline NPK (1) & 1,31 & 1,45 & 1,14 & 1,29 & 1,30 \\
2NPK (1) & 1,40 & 1,46 & 1,04 & 1,32 & 1,31 \\
Crotalaria juncea & 3,08 & 3,20 & 2,93 & 2,96 & 3,04 \\
Crotalaria spectabilis & 1,30 & 1,28 & 1,32 & 1,29 & 1,30 \\
Guandú & 2,26 & 2,54 & 1,98 & 1,98 & 2,19 \\
Mucuna preta & 0,79 & 0,80 & 0,75 & 0,76 & 0,78 \\
Mucuna anã & 0,64 & 0,54 & 0,74 & 0,70 & 0,66 \\
Labe labe & 0,83 & 0,79 & 0,84 & 0,82 & 0,82 \\
Feijão de porco & 0,88 & 0,76 & 1,00 & 0,95 & 0,90 \\
\hline
\end{tabular}

Obs: 1 - Altura das plantas daninhas

Analisando os dados observa-se, como era de esperar, que as leguminosas lenhosas (crotalárias e guandú), apresentaram maiores alturas. Essas diferenças de altura entre as espécies, são determinadas pelo hábito de crescimento arbustivo ou rasteiro como é o caso da mucuna preta, mucuna anã e labe labe. Estes valores médios de altura das plantas, estão dentro das médias descritas por NEME (1940).

Alguns produtores evitam a semeadura de espécies de porte alto como cultura intercalar devido ao sombreamento que possa ocorrer, porém, deve-se deixar uma distância adequada entre a linha de citros e a linha de plantio de adubo verde, para que não ocorra sombreamento e inibição fotossintética.

As Fotos de 1 a 8 , ilustram os tratamentos com respectivamente $C$. juncea, C. spectabilis, guandú, mucuna preta, mucuna anã, labe labe, feijão de porco e parcela testemunha com as plantas daninhas infestantes. 


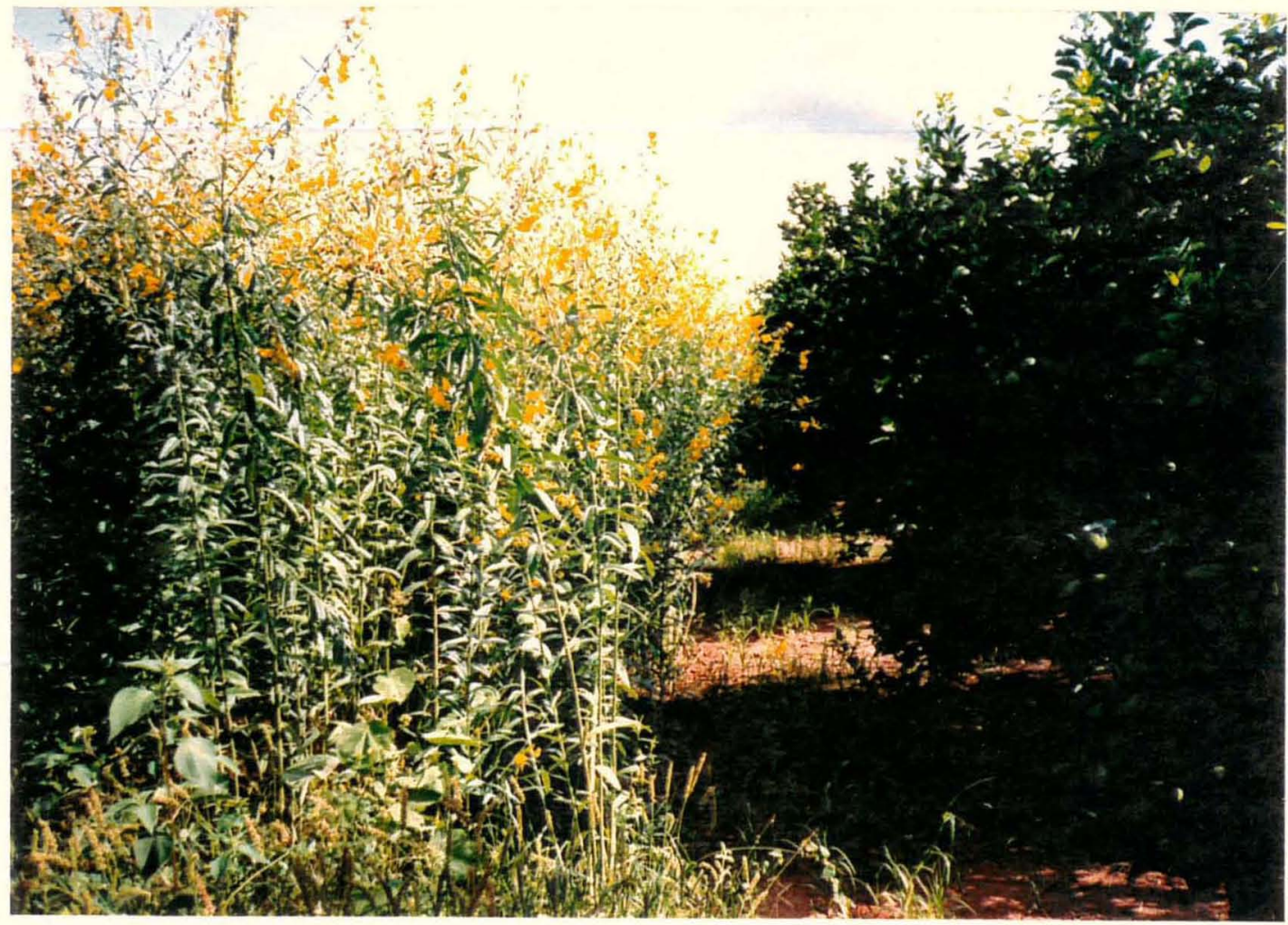

FOTO 1. Aspectos da área experimental com Crotalaria juncea, intercalar ao citros

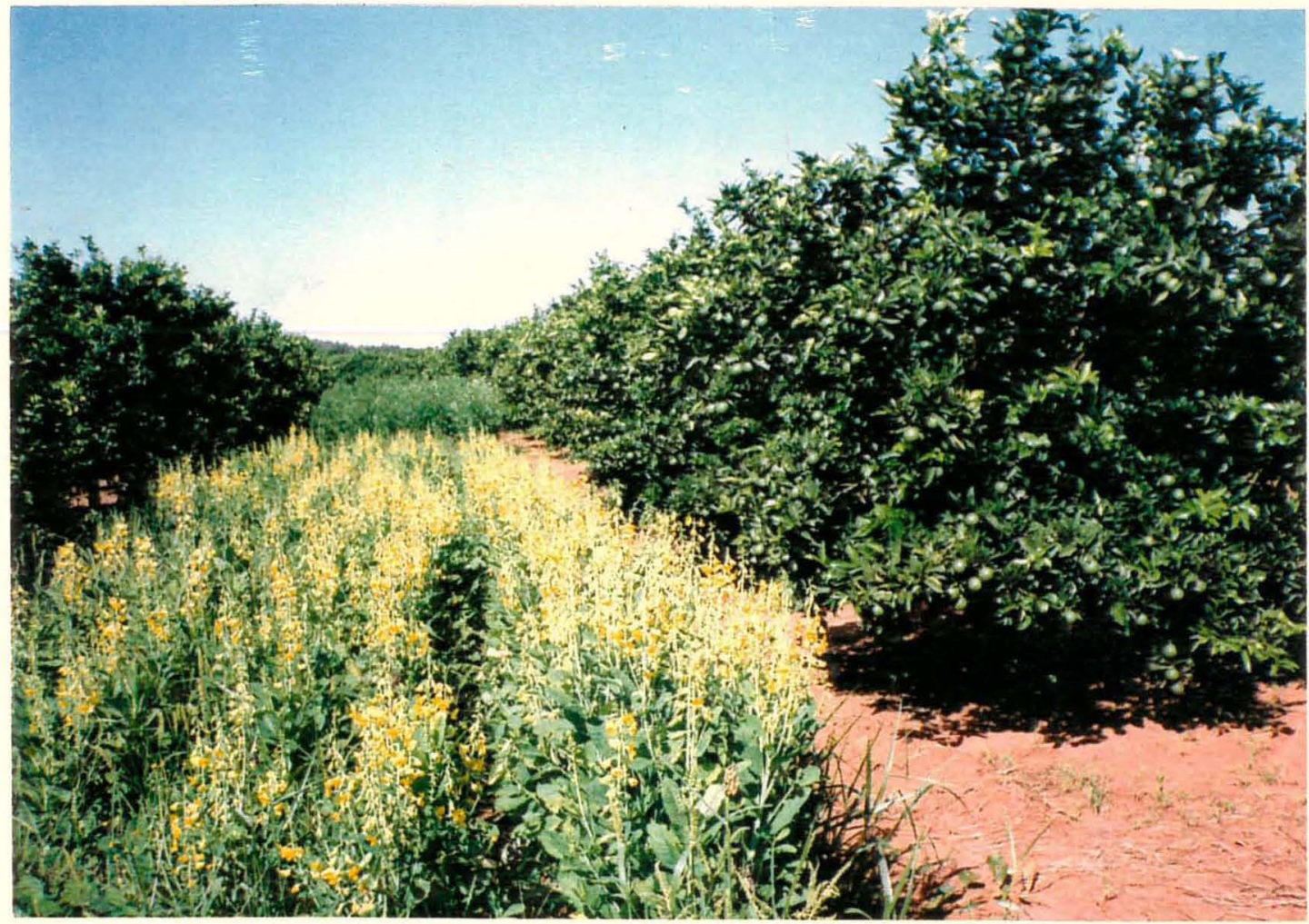

FOTO 2. Aspectos da área experimental com Crotalaria spectabilis, intercalar ao citros 


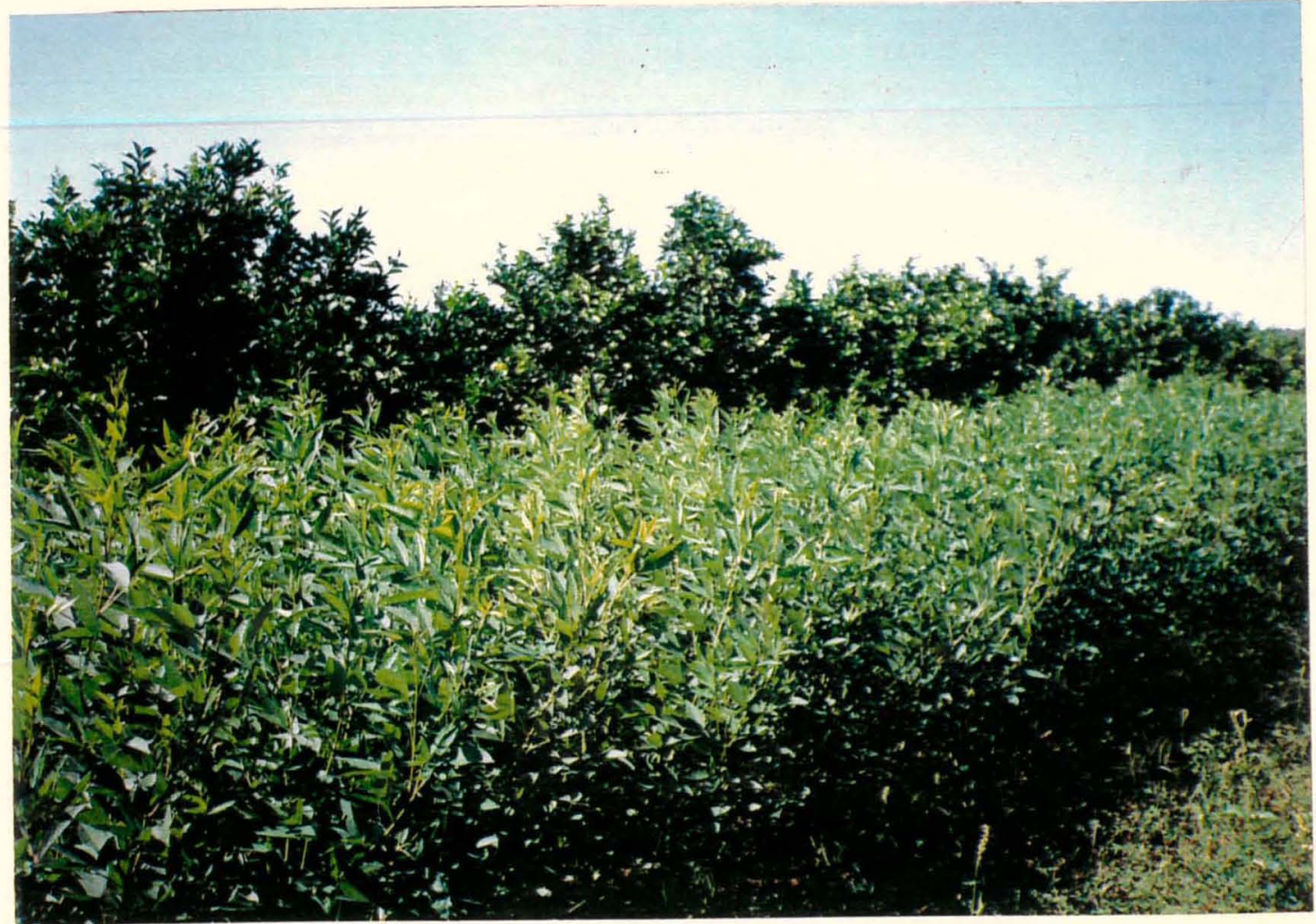

FOTO 3. Aspectos da área experimental com guandú, intercalar ao citros

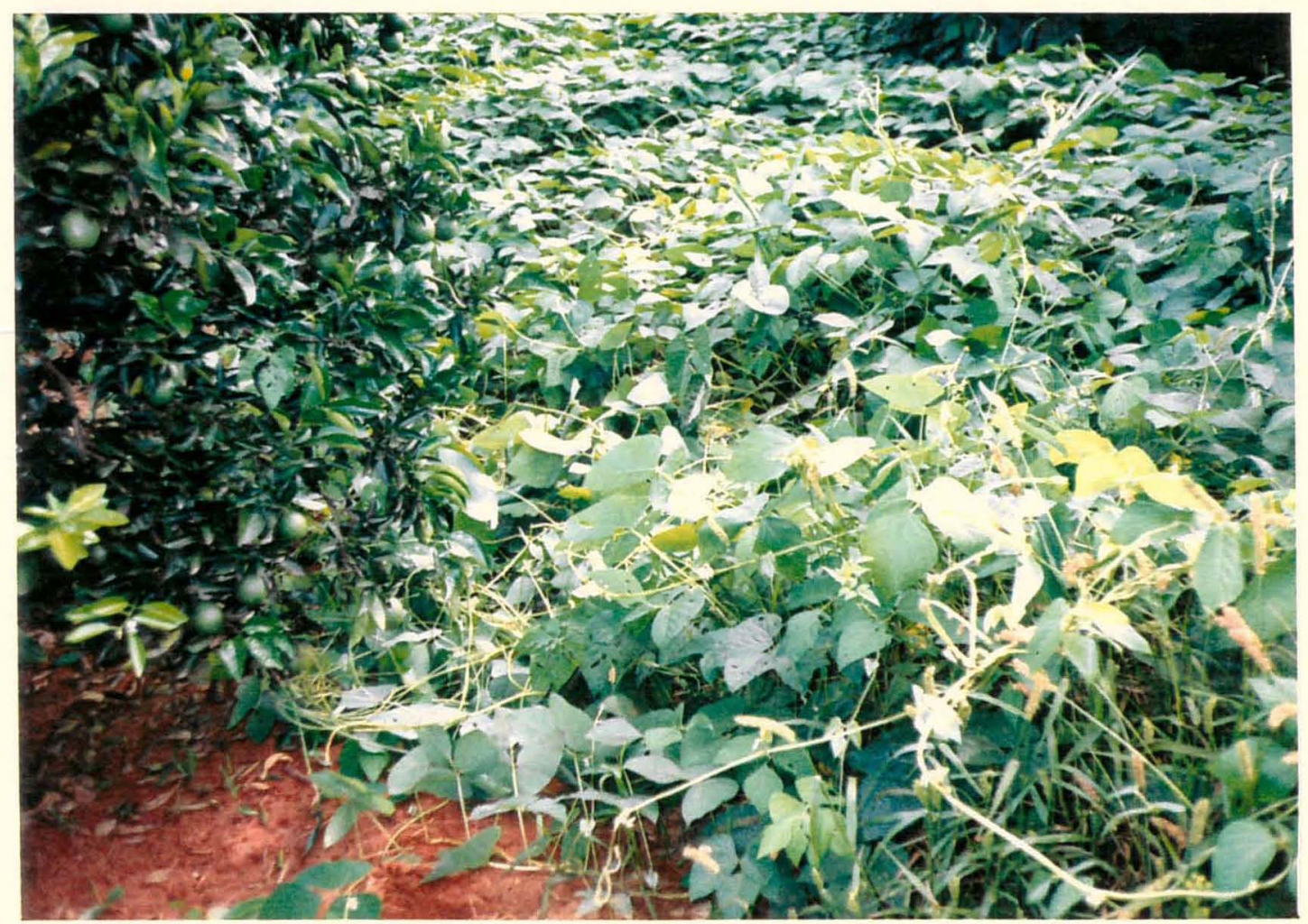

FOTO 4. Aspectos da área experimental com mucuna preta, intercalar ao citros 


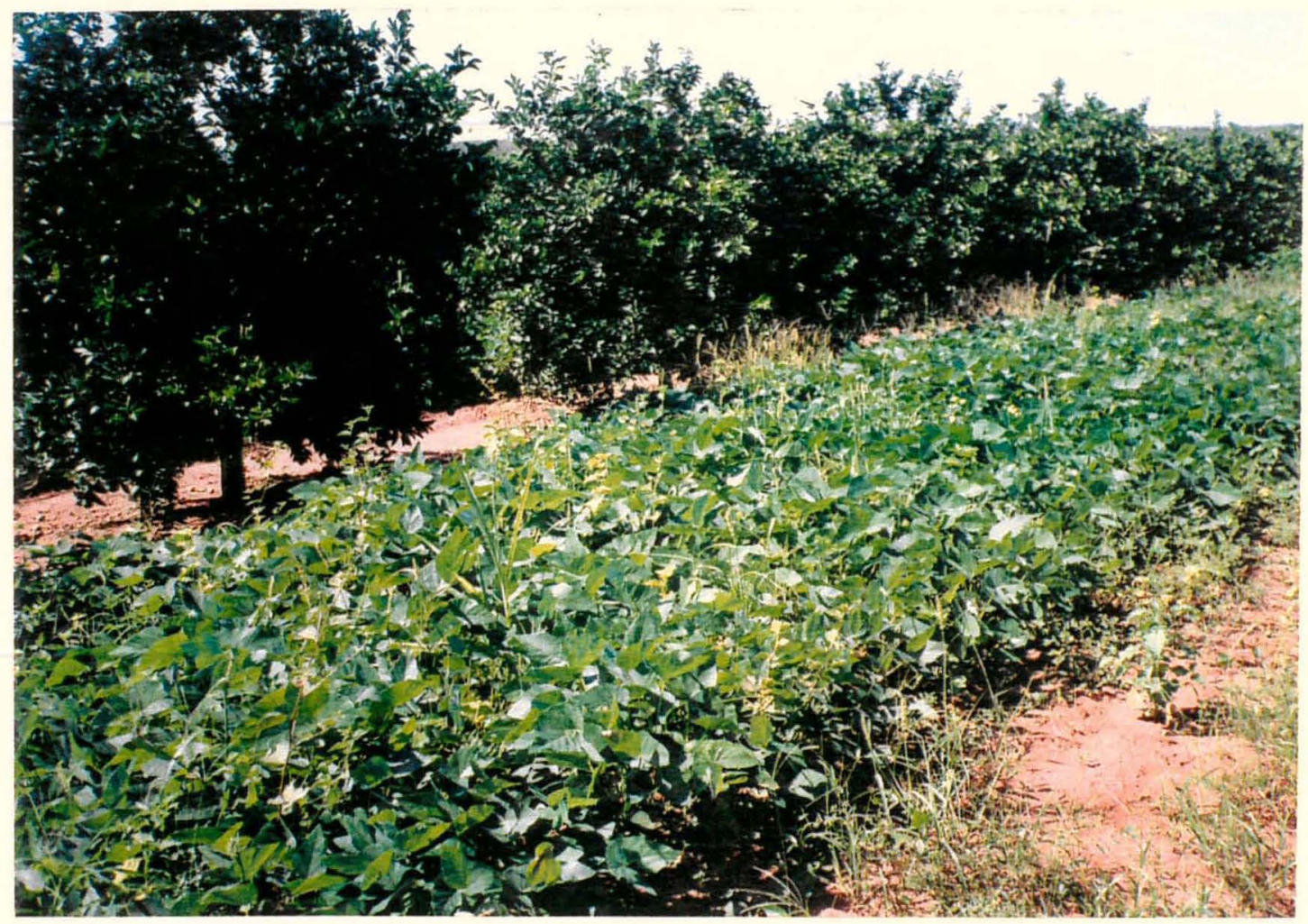

FOTO 5. Aspectos da área experimental com mucuna anã, intercalar ao citros

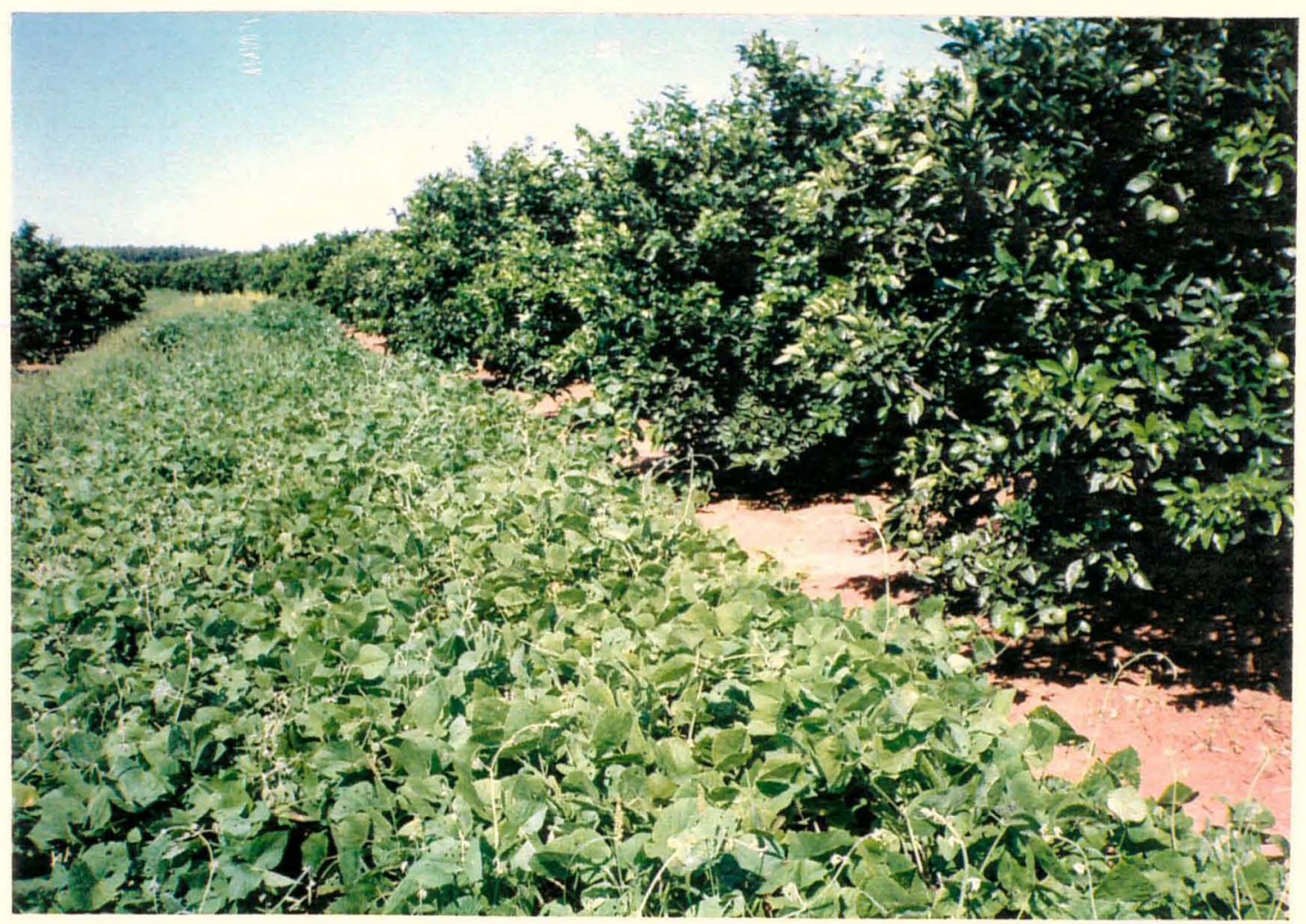

FOTO 6. Aspectos da área experimental com labe labe, intercalar ao citros 


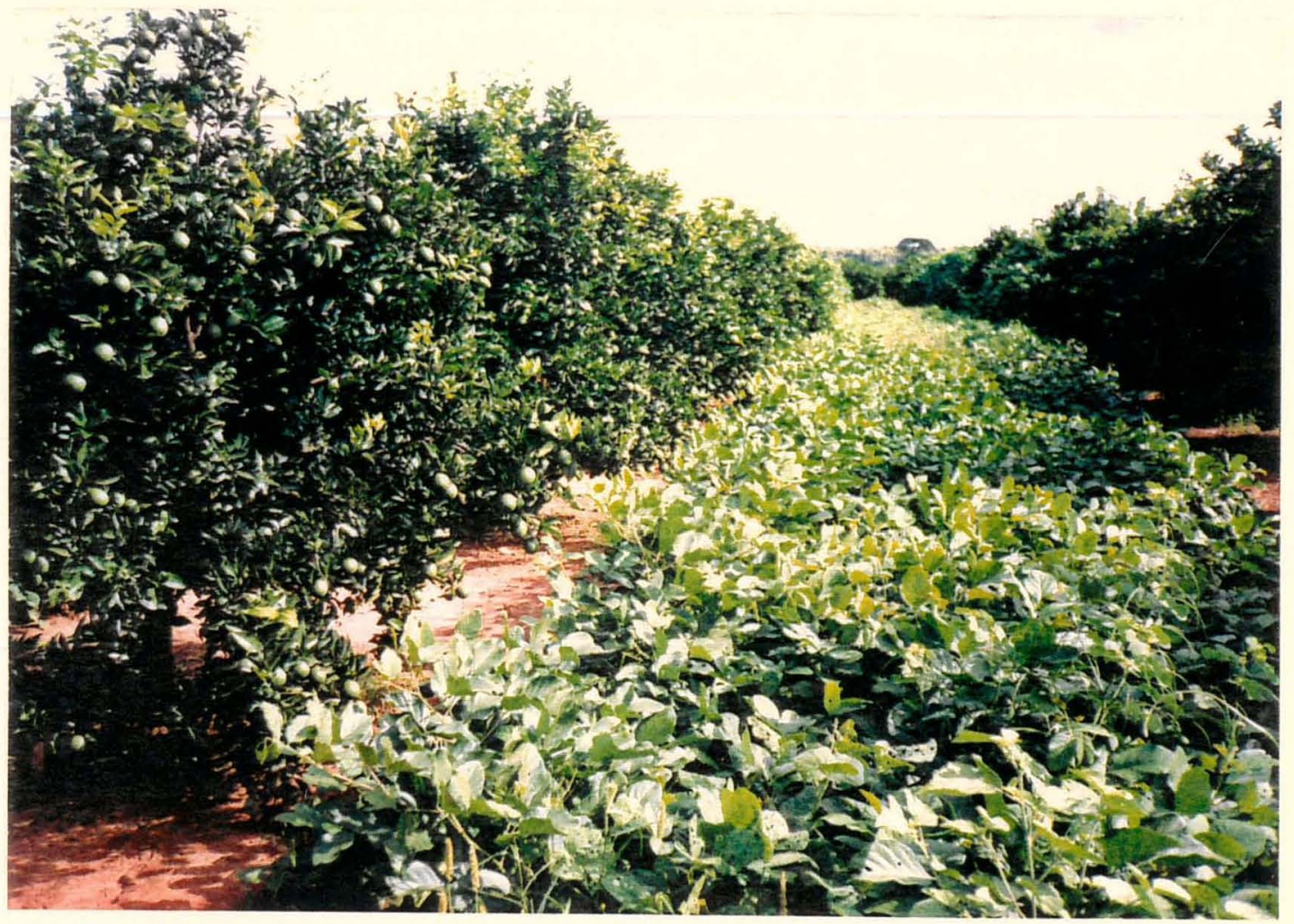

FOTO 7. Aspectos da área experimental com feijão de porco, intercalar ao citros

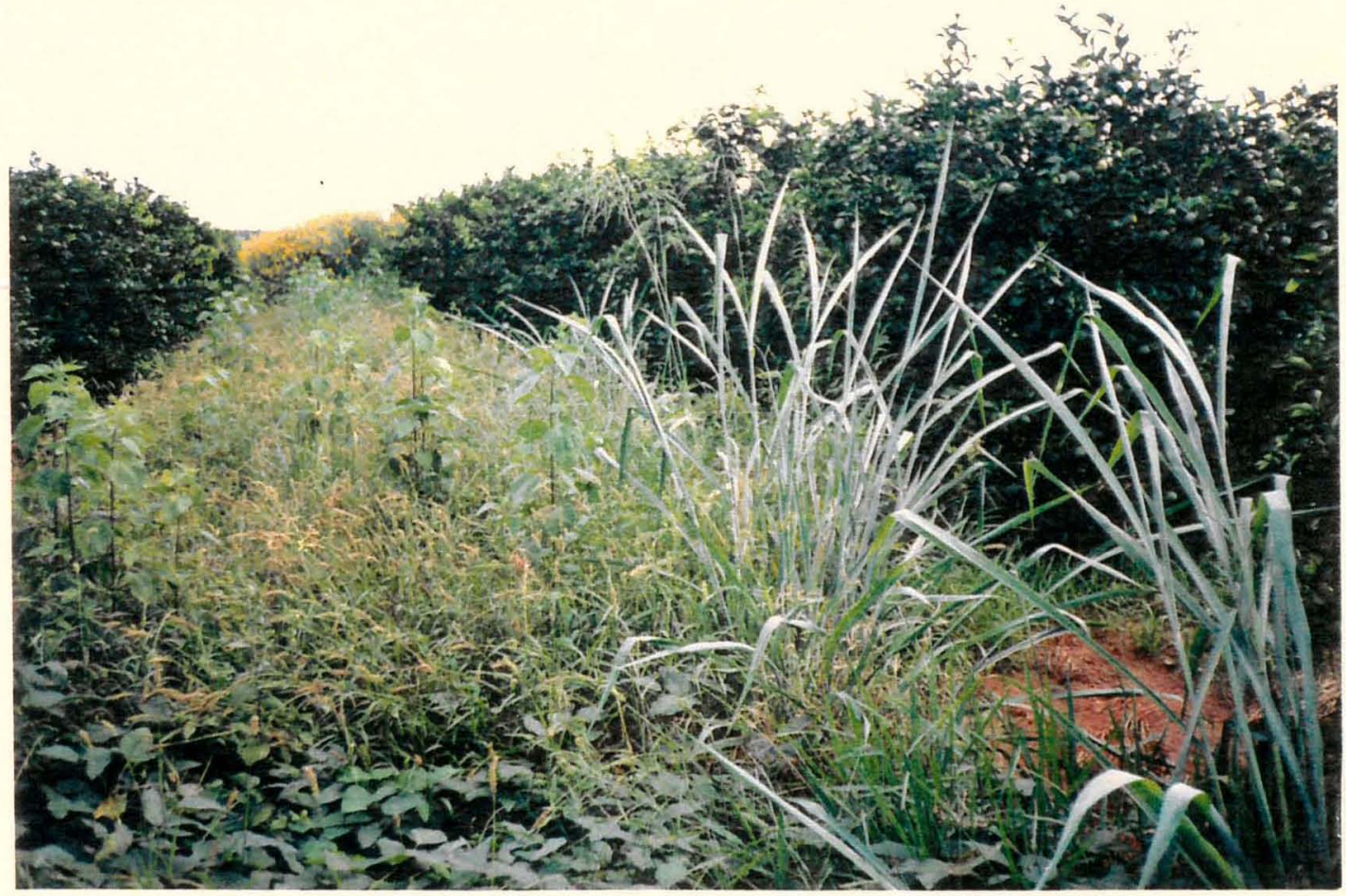

FOTO 8. Aspéctos das parcelas (NPK e 2NPK), com plantas daninhas nativas, intercalar ao citros 


\subsection{Avaliação da incidência de plantas daninhas nas parcelas}

Na Tabela 10, apresenta-se as porcentagens médias de plantas daninhas incidentes nas parcelas com e sem adubos verdes. Analisando estes dados observa-se que nas parcelas com Crotalaria juncea e com mucuna preta, foi mais efetivo o controle do mato. Estes números foram obtidos antes do corte das plantas nas parcelas, tomando-se como $100 \%$ os tratamentos testemunhas onde não se plantaram as leguminosas que apresentavam grande diversidade de espécies de plantas daninhas.

As espécies eleitas como adubo verde, normalmente têm germinação, crescimento e fechamento rápidos, não permitindo o desenvolvimento das plantas daninhas, porém a Crotalaria spectabilis e o guandú, por terem características de desenvolvimento inicial lento, não dominam o mato na fase inicial. Somente o guandú consegue "fechar" a área mais tarde. Como se pode observar na Tabela 5, a mucuna anã apresentou a média de $8 \%$ de mato nas parcelas devido a suscetibilidade ao fungo da cercosporiose, que afetou a sobrevivência e desenvolvimento, provocando a queda das folhas prematuramente.

No demais tratamentos a porcentagem média de plantas daninhas nas parcelas foi baixa, não apresentando competição severa com as leguminosas.

Devido a sobrevivência de algumas leguminosas estar abaixo do recomendado, algumas espécies de plantas daninhas encontraram condições de desenvolvimento, portanto, o seu nível de ocorrência está relacionado com o nível da germinação do adubo verde e da sua cobertura do solo, entretanto, mesmo para o tratamento com a Crotalaria spectabilis, a média de incidência de plantas daninhas foi muito baixa (cerca de $9 \%$ ), indicando que todos os adubos verdes, foram eficientes na cobertura do solo. 
TABELA 10. Porcentagem média de plantas daninhas observada nas parcelas

\begin{tabular}{|c|c|c|c|c|c|}
\hline \multirow[t]{2}{*}{ Tratamento } & \multicolumn{5}{|c|}{ Porcentagem de plantas daninhas } \\
\hline & $1989 / 90$ & $1990 / 91$ & $1991 / 92$ & $1992 / 93$ & Média \\
\hline NPK & 100 & 100 & 100 & 100 & 100 \\
\hline 2NPK & 100 & 100 & 100 & 100 & 100 \\
\hline Crotalaria juncea & 0 & 0 & 0 & 0 & 0 \\
\hline Crotalaria spectabilis & 10 & 9,5 & 10,5 & 5 & 9 \\
\hline Guandú & 3,3 & 0 & 0 & 0 & 1 \\
\hline Mucuna preta & 0 & 0 & 0 & 0 & 0 \\
\hline Mucuna anã (1) & 3 & 10 & 10 & 7 & 8 \\
\hline Labe labe & 4,3 & 3,8 & 1,5 & 1,5 & 3 \\
\hline Feijão de porco & 2 & 3 & 4.0 & 2 & 3 \\
\hline
\end{tabular}

Obs: 1 - Sofreu ataque de cercosporiose

\subsection{Identificação das espécies de plantas daninhas incidentes}

As espécies de plantas daninhas nativas de maior ocorrência nos quatro anos e em ordem decrescente de ocorrência, estão apresentada na Tabela 11.

Foram observadas diferenças de ocorrência de espécies de plantas daninhas nos diferentes tratamentos, o que indica a possível influência dos adubos verdes, seja pelo desenvolvimento rápido das plantas e consequente sombreamento, seja por efeitos de inibição das plantas daninhas.

Observa-se que nos quatro anos de condução do experimento, as espécies e a ordem decrescente dos dois tratamentos testemunhas (NPK e 2NPK), onde não se semeou adubo verde, não sofreram alterações, havendo diferença de ocorrência, provavelmente por efeitos alelopáticos das mesmas sobre as plantas daninhas. 
TABELA 11. Espécies de plantas daninhas de maior ocorrência nas parcelas, nos anos agrícolas 1989/90, 90/91, 91/92 e 92/93

\begin{tabular}{|c|c|c|c|}
\hline \multirow[t]{2}{*}{ Tratamento } & \multicolumn{3}{|c|}{ Espécies de maior ocorrência em 4 anos } \\
\hline & $1^{a}$ & $2^{\mathrm{a}}$ & $3^{\mathrm{a}}$ \\
\hline NPK & Capim carrapicho ${ }^{(1)}$ & Braquiaria $^{(2)}$ & Capim colonião ${ }^{(3)}$ \\
\hline $2 \mathrm{NPK}$ & Capim carrapicho & Braquiaria & Capim colonião \\
\hline Crotalaria juncea & - & - & - \\
\hline Crotalaria spectabilis & Guanxuma $^{(4)}$ & Braquiaria & Capim carrapicho \\
\hline Guandú & Braquiaria & Capim carrapicho & Guanxuma \\
\hline Mucuna preta & - & - & - \\
\hline Mucuna anã & Capim carrapicho & Picão preto ${ }^{(5)}$ & Guanxuma \\
\hline Labe labe & Capim carrapicho & Guanxuma & Picão preto \\
\hline Feijão de porco & Capim carrapicho & Guanxuma & Picão preto \\
\hline
\end{tabular}

Obs: Nome comum e cientifico das espécies incidentes: 1- Capim carrapicho - Cenchrus echinatus $\mathrm{L}$.; 2- Braquiária - Brachiaria sp.; 3-Capim colonião - Panicum maximum Jacq. ; 4- Guanxuma - Sida sp.; 5- Picão preto - Bidens pilosa $\mathrm{L}$.

As diferenças mostradas podem ter ocorrido por competição, sombreamento ou pela acão alelopática, que ocorre em cada planta, tanto viva quanto em decomposicão, exercendo inibição sobre determinadas espécies de plantas daninhas ou cultivadas, porém não foi determinado este efeito.

Um fato interessante, é a ocorrência de guanxuma, planta daninha de folha larga, somente nos tratamentos com adubação verde, enquanto que a ocorrência de Braquiaria, possível hospedeira das cigarrinhas (Acrogonia terminalis, Dilobopteus costalimai e Oncometopia sp.), que transmitem a bactéria Xilella fastidiosa causadora da doença chamada C.V.C. (clorose variegada dos citros), ocorreu somente nas parcelas sem o emprego de adubação verde, bem como, nas parcelas onde se cultivou o guandú. Surge assim, a possibilidade de através do emprego de adubação verde, alterar a ocorrência de invasão por certos tipos de plantas daninhas, alterando assim a ocorrência de pragas e doenças na cultura de citros. 


\subsection{Resultados das análises foliares dos citros}

Os teores de nutrientes nas amostras de folhas de citros, estão apresentados na Tabela 12.

De posse dos resultados das análises foliares dos citros, podemos observar que para o $\mathrm{N}$ (nitrogênio), não houve diferença significativa entre os tratamentos, porém observa-se diferenças significativas entre os anos, destacando os maiores teores nos anos agrícolas $89 / 90$ e $91 / 92$ e menor no ano agrícola de 92/93. Conforme o GRUPO PAULISTA (1994), os valores obtidos estão dentro do nível considerado adequado que é de 23 a $27 \mathrm{~g} / \mathrm{kg}$. Observa-se que os tratamentos que receberam adubação química nitrogenada (NPK e 2NPK), os valores de $\mathrm{N}$ foliar não diferem dos tratamentos onde se utilizaram apenas adubo verde, sem a aplicação de $\mathrm{N}$ combinado, indicando quanto a esse parâmetro que os tratamentos com adubo verde, podem ter sido suficientes em fornecer nitrogênio para o citros.

Para o P (fósforo), nos anos agrícolas de 89/90, 91/92 e 92/93, os níveis estão adequados de acordo com o GRUPO PAULISTA (1994), que é de 1,2 a $1,6 \mathrm{~g} / \mathrm{kg}$. No ano agrícola de $92 / 93$, observa-se uma queda generalizada entre os tratamentos em relação aos anos anteriores, ficando o guandú, a mucuna preta, a mucuna anã, o labe labe e o feijão de porco, com teores considerados baixos (menor que $1,2 \mathrm{~g} / \mathrm{kg}$ ), segundo GRUPO PAULISTA (1994). GALLO \& RODRIGUES, (1960), em experimento conduzido durante quatro anos na cultura de citros, observaram que a adubação verde com mucuna preta, aumentou de modo sensível o teor de $\mathbf{P}$ nas folhas dos citros $\mathrm{e}$ acompanhando o aumento dos níveis desse elemento nas folhas aumentou também as produções. 


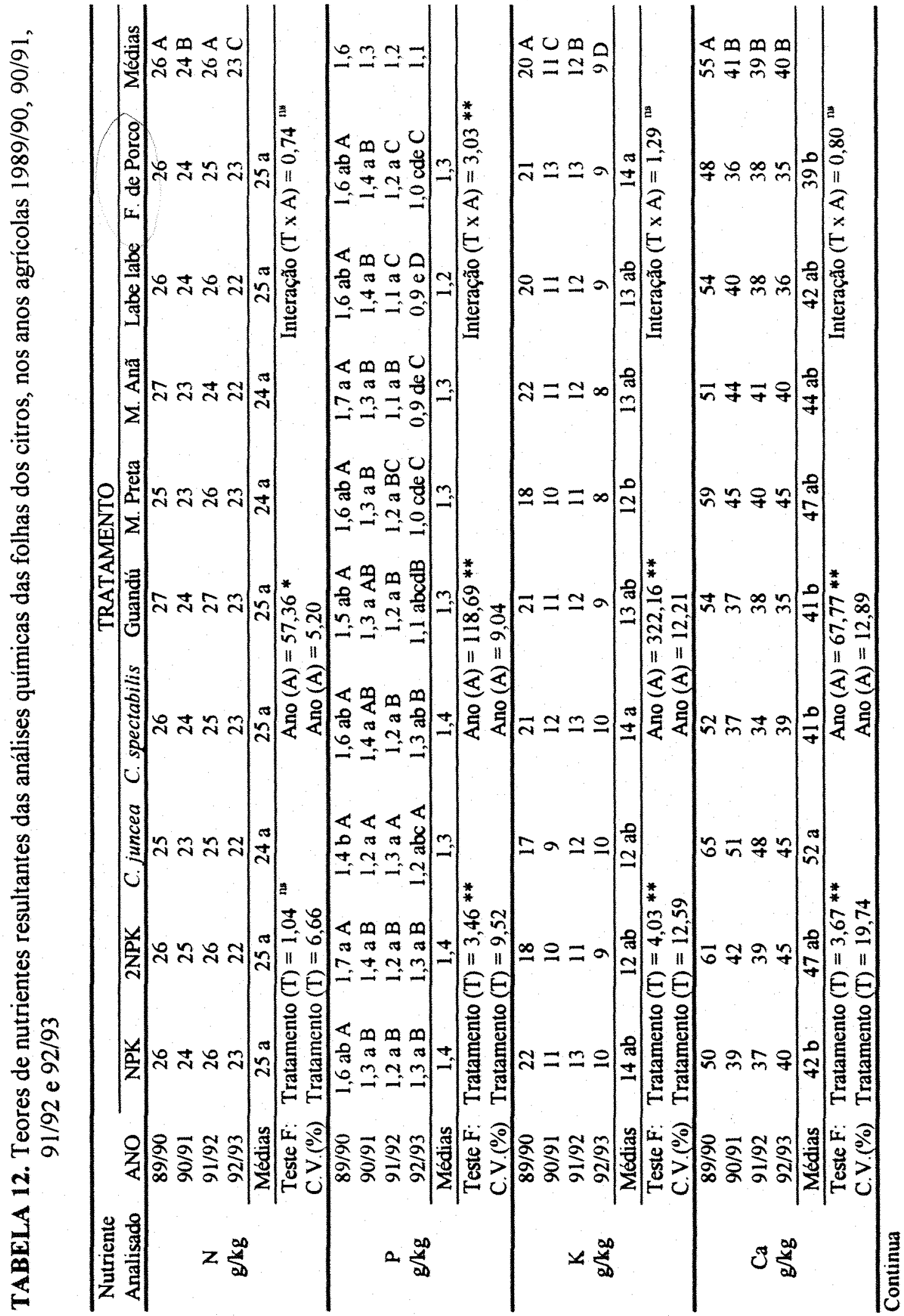




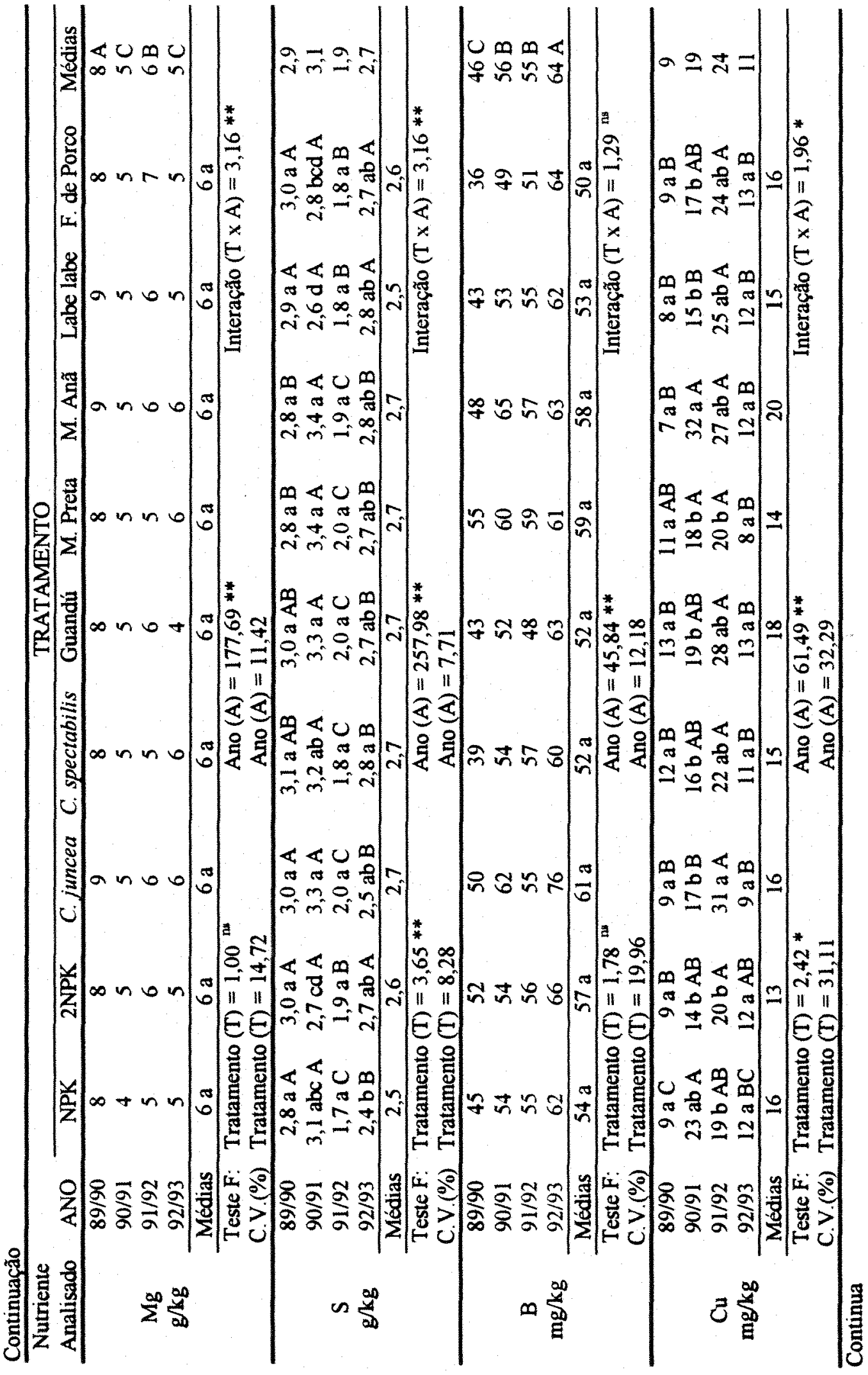




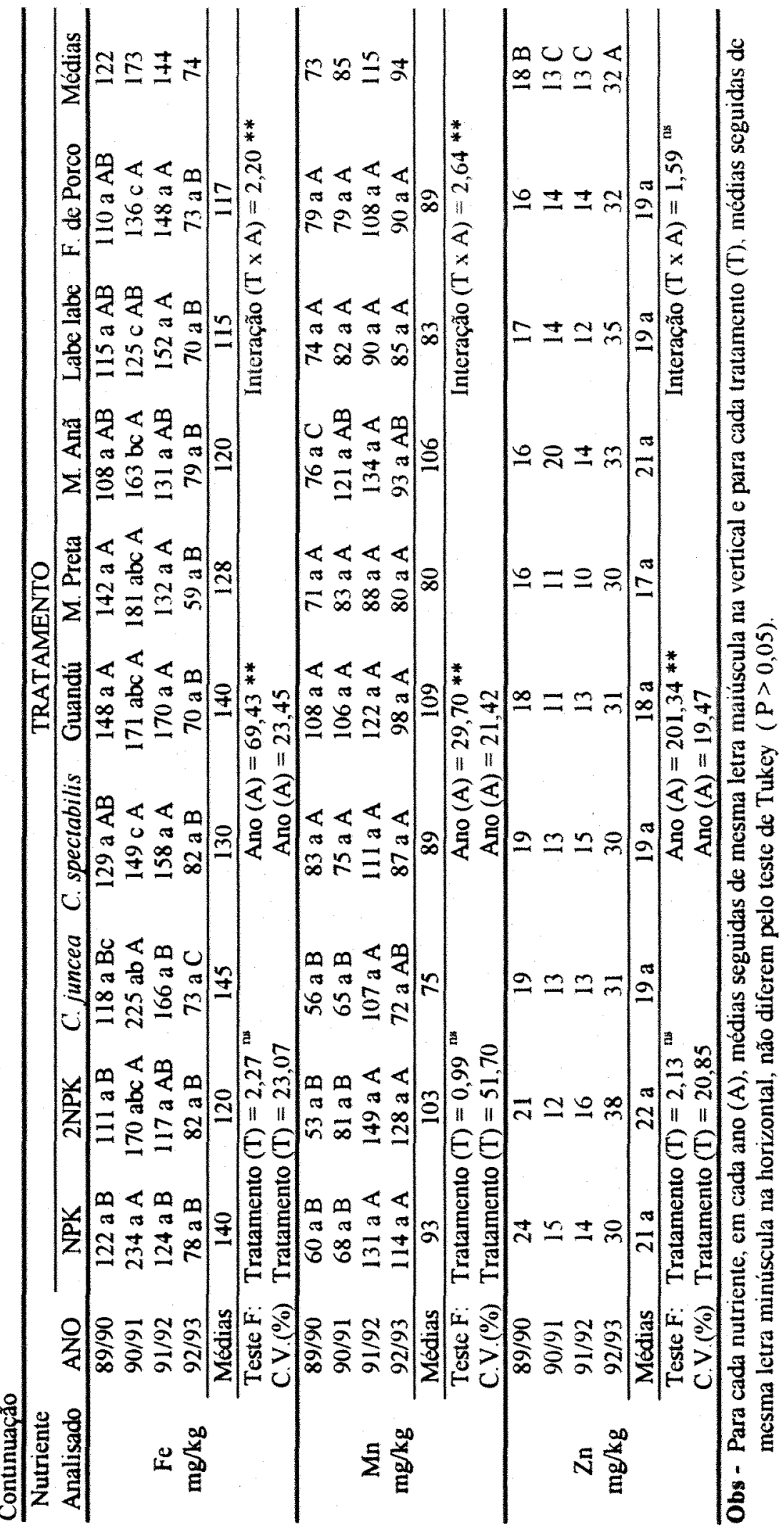


Os teores foliares de $\mathrm{K}$ (potássio), apresentaram no primeiro plantio teores excessivos deste elemento (maior que $20 \mathrm{~g} / \mathrm{kg}$ ), com exceção da Crotalária juncea e mucuna anã, que apresentavam valores considerados adequados $(10$ a $15 \mathrm{~g} / \mathrm{kg})$, junto com todos os tratamentos do $2^{\circ}$ e $3^{\circ}$ ano. Observa-se o decréscimo dos teores de $\mathrm{K}$ no $4^{\circ}$ ano onde, os tratamentos passaram a mostrar teores considerados baixos $(<10 \mathrm{~g} / \mathrm{k})$, conforme GRUPO PAULISTA (1994).

Para os teores foliares de $\mathrm{Ca}$ (cálcio), o primeiro ano apresentou para os tratamentos, teores considerados altos (>50g/kg), segundo GRUPO PAULISTA (1994), sendo que o feijão de porco apresentou teores menores significativamente deste nutriente.

Quando avaliou-se os teores de Mg (magnésio) nas folhas de citros, observa-se a mesma tendência de maiores teores no primeiro ano agrícola com queda ano a ano, porém não existiu diferenças significativas entre os tratamentos e todos encontram-se dentro dos níveis considerados excessivos ( $>5 \mathrm{~g} / \mathrm{kg}$ ), conforme GRUPO PAULISTA (1994).

Para o $1^{\circ}$ e $2^{\circ}$ ano os teores foliares de $S$ (enxofre), apresentaram-se adequados $(2,0 \mathrm{a} 3,0 \mathrm{~g} / \mathrm{kg})$, em todos os tratamentos, já no $3^{\circ}$ ano observa-se a tendência de abaixamento significativo desses teores, a nível considerado baixo $(<2,0 \mathrm{~g} / \mathrm{kg})$, nos tratamentos em relação aos demais anos, voltando a niveis adequados no $4^{\circ}$ ano. As plantas das parcelas com labe labe destacaram pelos menores teores de $\mathrm{S}$.

Os micronutrientes analisados, apresentaram oscilações nos seus teores entre os tratamentos e anos avaliados.

Os teores foliares de B (boro) não apresentaram diferenças significativas entre os tratamentos, estando seus teores entre 36 e $100 \mathrm{mg} / \mathrm{kg}$, considerado adequado pelo GRUPO PAULISTA (1994), observando sim aumento gradativo do primeiro para o quarto ano (média de 46 para $64 \mathrm{mg} / \mathrm{kg}$ ).

Para o $\mathrm{Cu}$ (cobre), observa-se maiores teores no $2^{\circ}$ e $3^{\circ}$ ano, estando os valores de adequado $(4,1$ a $10 \mathrm{mg} / \mathrm{kg})$ a excessivo $(>15 \mathrm{mg} / \mathrm{kg})$.

Os teores foliares de $\mathrm{Fe}$ (ferro), apresentaram valores considerados adequados (50-120 mg/kg), segundo GRUPO PAULISTA (1994), porém observa-se 
uma queda significativa nos teores deste nutriente no $4^{\circ}$ ano. Entre os tratamentos a diferença é não significativa.

O Mn (manganês), apesar de não ter apresentado diferença significativa entre os tratamentos, com níveis de adequados ( 35 a $50 \mathrm{mg} / \mathrm{kg}$ ) a excessivos ( $>100 \mathrm{~g} / \mathrm{kg}$ ), mostrou um aumento dos teores do $1^{\circ}$ ao $3^{\circ}$ ano, com queda no $4^{\circ}$ ano.

Quanto ao Zn (zinco), este não apresentou diferença significativa entre os tratamentos, porém os teores foliares do nutriente nos citros aumentou do $1^{\circ}$ para o $4^{\circ}$ ano, apesar dos valores serem considerado baixos $(<35 \mathrm{mg} / \mathrm{kg})$, segundo GRUPO PAULISTA (1994). Os menores teores de $\mathrm{Zn}$, apesar de não significativo foram apresentados pela mucuna preta e guandú.

Analisando os resultados do experimento em questão, nos quatro anos agrícolas estudados, observa-se que ocorreram poucas diferenças significativas entre os tratamentos e anos. A observação mais importante, entretanto, é quanto ao teor de nitrogênio $(\mathrm{N})$, qual, não apresentou diferenças significativas, entre as parcelas testemunhas que receberam aplicação de $\mathrm{N}$ mineral e as com leguminosas, que não receberam essa aplicação, indicando que o cultivo e/ou decomposicão das mesmas, podem ter sido suficiente para o fornecimento desse elemento à cultura de citros.

\subsection{Determinação do diâmetro de caule e volume de copa das plantas cítricas}

Os resultados das médias obtidas nas medições, comparando os tratamentos dentro dos quatro anos agrícolas, mostrando a evolução no desenvolvimento das plantas cítricas, estão apresentados na Tabela 13. Tanto o diâmetro de tronco, quanto o volume de copa das plantas cítricas avaliadas, não apresentaram diferenças significativas entre os tratamantos. Estes dados mostram que, mesmo sem a adubação nitrogenada, os tratamentos com as espécies leguminosas mantiveram desenvolvimento igual ou superior, apesar de não significativo estatisticamente ao nível de $5 \%$ de probabilidade, pelo teste de Tukey. 
옹

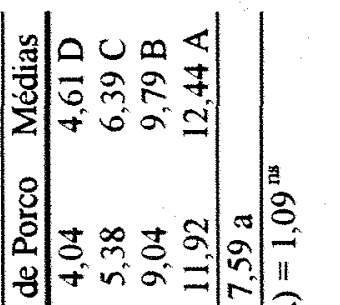

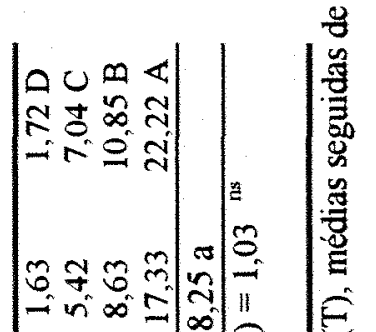

惑

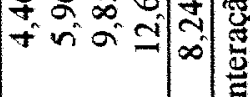

$\hat{a}$

สิ

\&

氙

g

$\bar{a}$

ริ

요

ङ

న

in

$\frac{4}{4}$

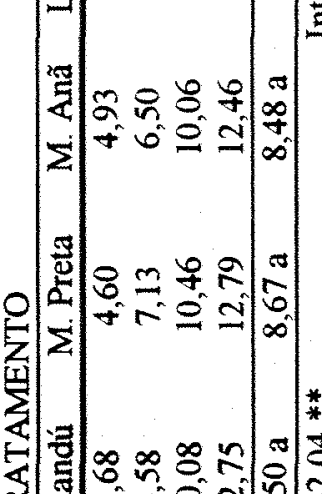

s

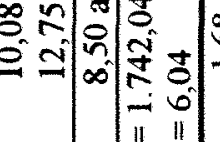

F.

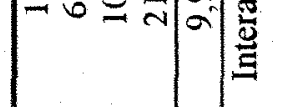

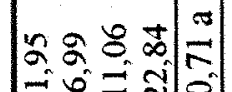

宽

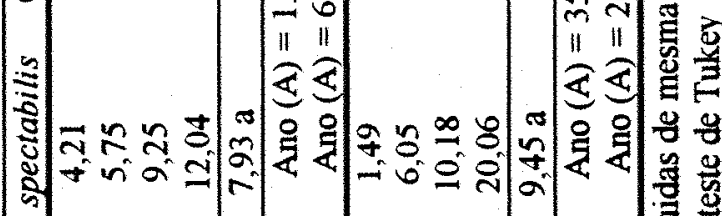

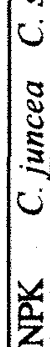

光

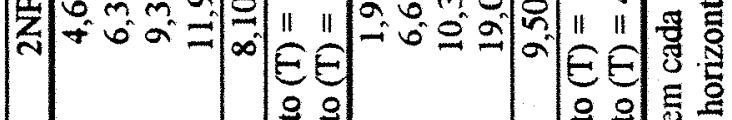

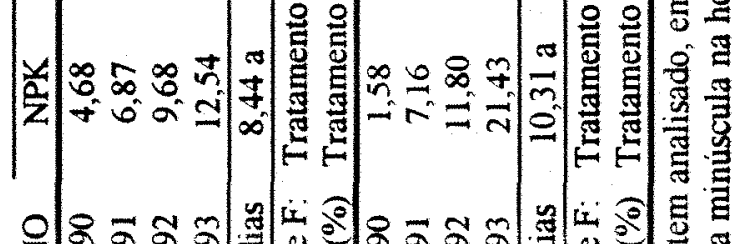

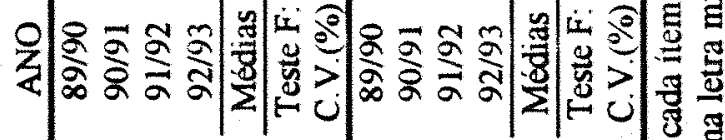

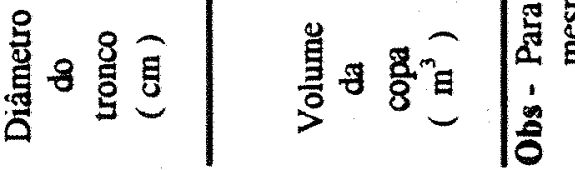




\subsection{Resultados das análises químicas do solo}

\subsubsection{Análises de solo retiradas na projeção da copa dos citros}

$\mathrm{Na}$ Tabela 14, estão apresentados os resultados de análises químicas do solo, obtidas a partir de amostras tomadas na projeção da copa das plantas de citros, aproximadamente 40 dias após a ultima parcela da adubação química recomendada, para as plantas cítricas, em cada ano agrícola.

Os resultados das características químicas do solo na projeção da copa mostraram que quanto ao $\mathrm{pH}$ do solo, as parcelas que receberam adubação química nitrogenada (Uréia), apresentaram maior ácidez, significativamente, reafirmando o efeito acidificante dos adubos nitrogenados. Com este resultado, podemos afirmar que em um pomar comercial, devam ser efetuada amostragens de solo na projeção da copa dos citros e outra nas entrelinhas, pois, como neste caso a calagem deve ser efetuada, aplicando quantidade maior de calcário na projeção da copa dos citros, onde se encontram os menores valores de $\mathrm{pH}$ do solo.

Os teores de MO (matéria orgânica), não se alteraram entre os tratamentos, pois na região amostrada o solo ficou descoberto devido ao uso de herbicida antes de cada plantio dos adubos verdes.

Os teores de $\mathrm{P}$ encontram-se dentro dos padrões de fertilidade para citros, recomendado pelo GRUPO PAULISTA (1994), com níveis considerados altos (>30 $\mathrm{mg} / \mathrm{dm}^{3}$ ), não apresentando diferença significativa entre os tratamentos, ocorrendo porém queda nos teores do nutriente considerado, após o ano agrícola 90/91.

O K não apresentou diferença significativa entre os tratamentos e observou-se pequena diminuição em seus teores dentro dos anos, estando os níveis entre 1,6 a 3,0 mmol $/ \mathrm{dm}^{3}$, que são considerados médios pelo GRUPO PAULISTA (1994).

Os teores de $\mathrm{S}, \mathrm{Ca}$ e $\mathrm{Mg}$ apesar de não apresentarem diferenças significativas entre os tratamentos, apresentaram aumento em seus teores em relação ao primeiro ano agrícola. Os teores de S encontram-se altos $\left(>10 \mathrm{mg} / \mathrm{dm}^{3}\right)$ e o de $\mathrm{Mg}$ estão em níveis médios ou seja em torno de 4 a $8 \mathrm{mmol} / \mathrm{dm}^{3}$. 
$\mathrm{O} \mathrm{H}+\mathrm{Al}$ apresentou entre os anos avaliados acréscimo médio dos teores de 40,0 para $46,5 \mathrm{mmol}_{\mathcal{d}} / \mathrm{dm}^{3}$ e entre tratamentos, observa-se valores significativamente maiores nos tratamentos sem adubo verde e menores nos tratamentos onde se utilizou adubação verde.

Quanto à soma por bases, a mesma não apresentou diferenças significativas entre os tratamentos, porém observou-se aumento dos valores no ano agrícola de 90/91 para o 92/93. Este aumento entre os anos também foi observado para o $\mathrm{T}$ (capacidade de troca de cátions) e V\% (saturação por bases); porém quanto ao $\mathrm{T}$, observou-se entre os tratamentos, maiores valores para o $2 \mathrm{NPK}$ e menores para a Crotalaria juncea e guandú; e o V\% apresenta diferença significativa para os tratamentos 2NPK, NPK e feijão de porco com menores valores e maiores para a Crotalaria juncea, labe labe, guandú e mucuna preta.

Em relação às características químicas do solo na projeção da copa, observa-se de modo geral entre os tratamentos, efeitos depressivos no valor de $\mathrm{pH}$ e aumento nos valores de $\mathrm{H}+\mathrm{Al}$ e de $\mathrm{T}$ no tratamento com adubação nitrogenada mineral e maiores valores de $\mathrm{V} \%$ nos tratamentos com adubação verde, exceto para o feijão de porco, não apresentando as demais características variações significativas. 


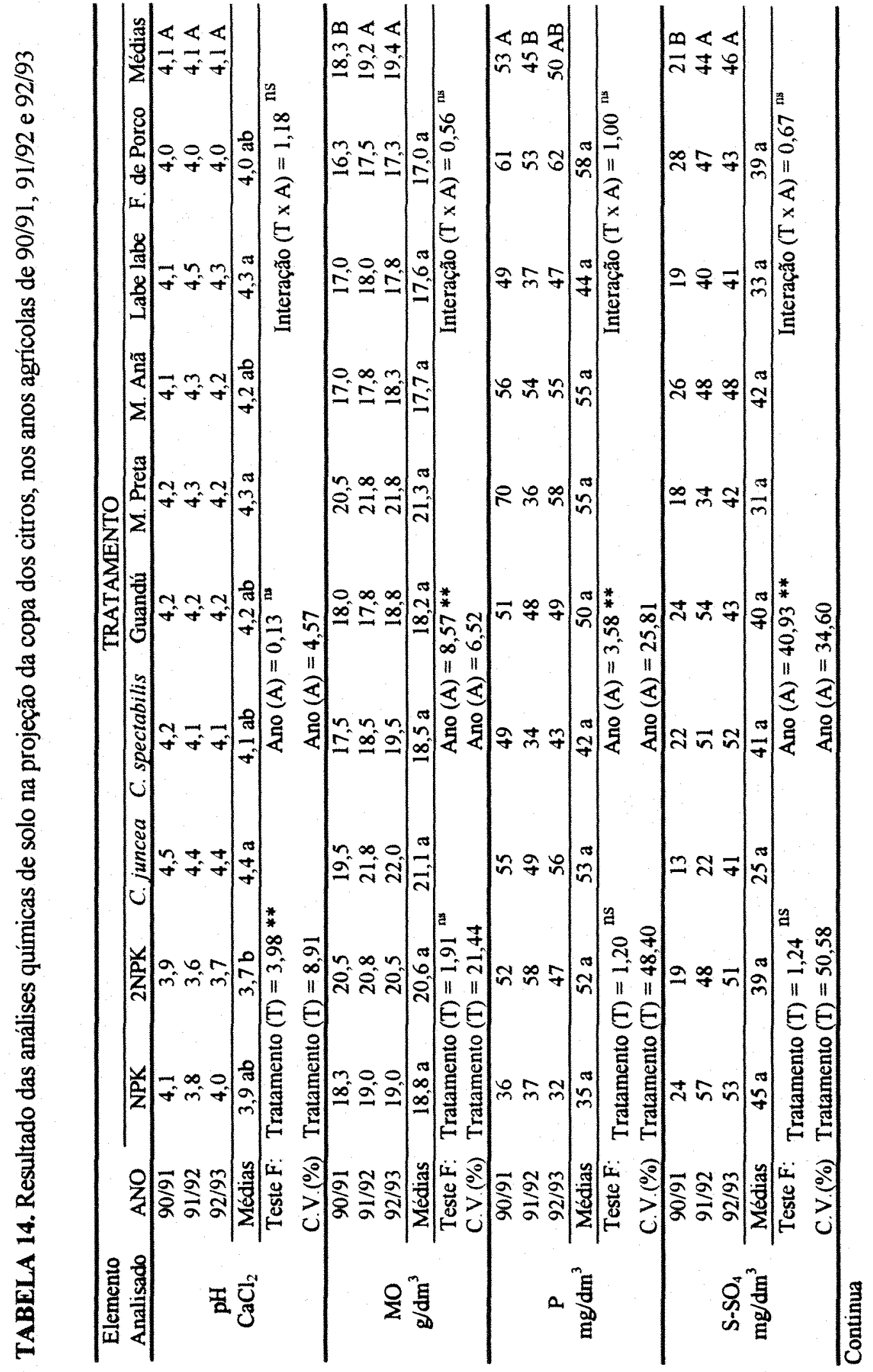




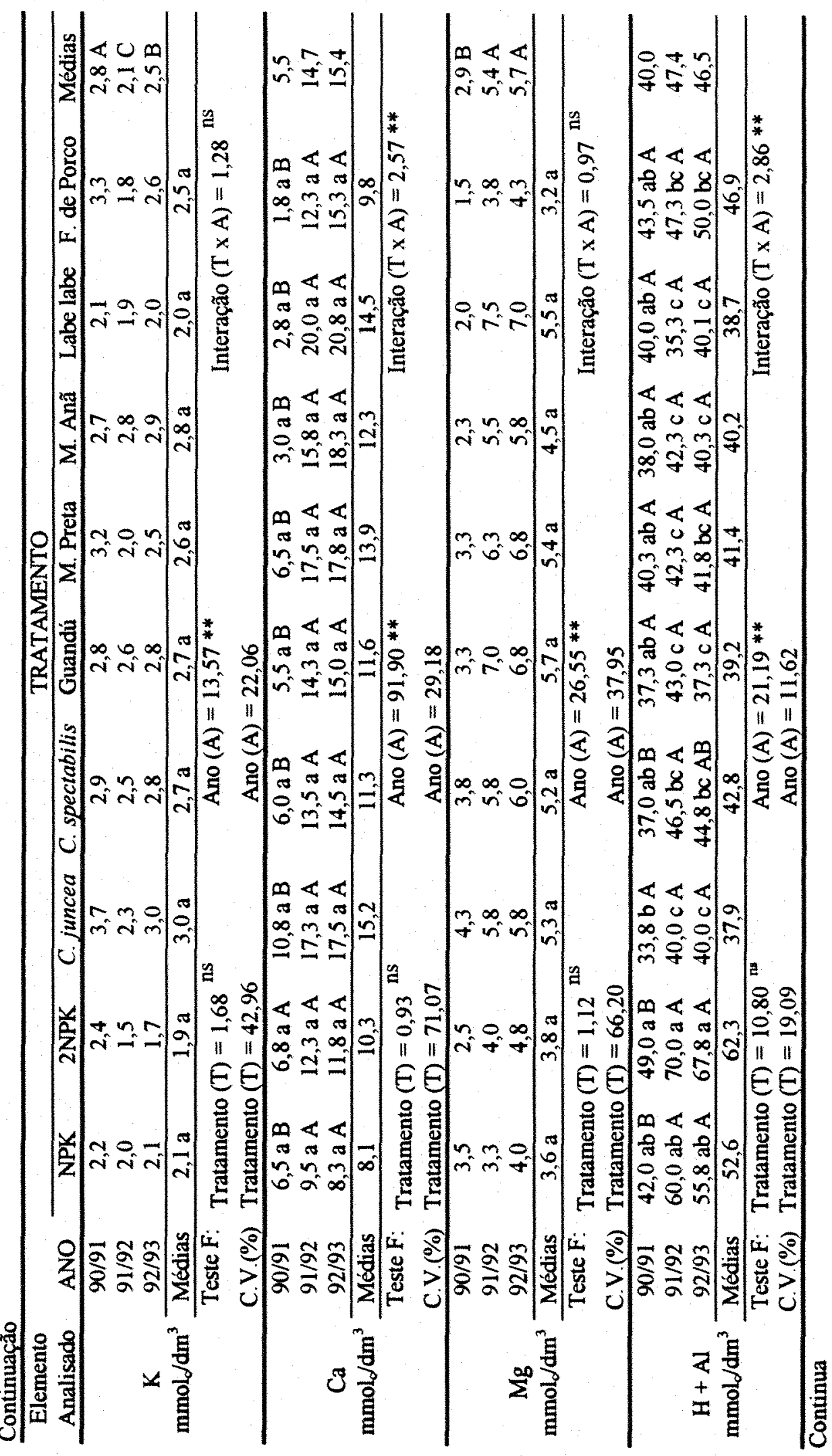




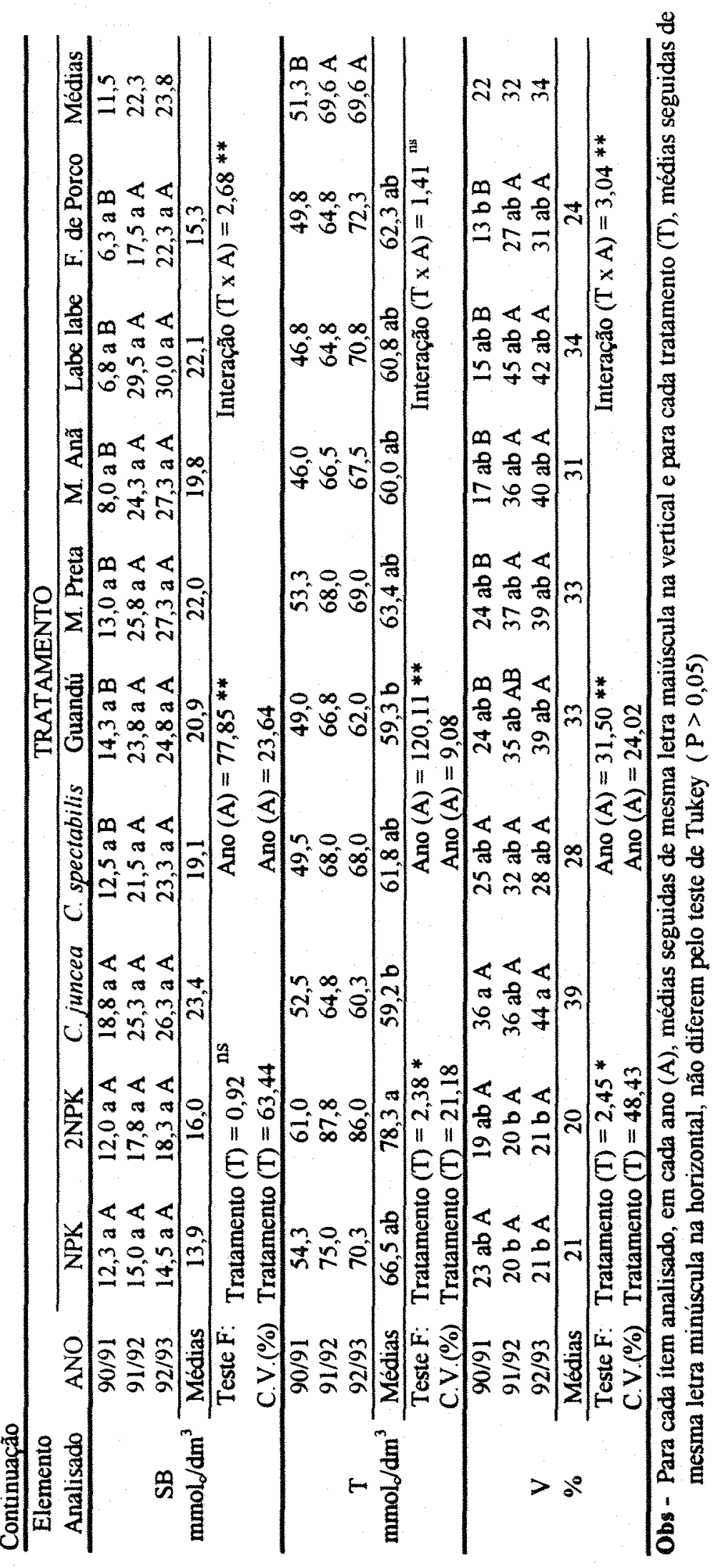




\subsubsection{Análise de solo retirada da entrelinha de citros, antes da semeadura} anual dos adubos verdes

$\mathrm{Na}$ instalação do experimento foi efetuada amostragem composta de solo representativa da área, sendo que os resultados estão apresentados no Tabela 1. Na Tabela 15 e 16, estão expressos os resultados das análises químicas de solo retirado das entrelinhas de citros (local de cultivo das leguminosas), nas profundidades de 0-20 e $20-40 \mathrm{~cm}$ respectivamente, nos anos agrícolas 90/91, $91 / 92$ e 92/93, correspondente antes da semeadura das leguminosas.

Os valores de $\mathrm{pH}$ mostraram que apesar de não apresentar diferenças significativas entre os tratamentos, ocorreu aumento de seus valores (média de 4,8 para 5,5) entre os anos agrícolas.

Os valores de $\mathrm{MO}$ obtidos nas parcelas com Crotalaria juncea $(\mathrm{C} / \mathrm{N}$ mais elevado), não difere dos demais, exceto das parcelas com labe labe $(\mathrm{C} / \mathrm{N}$ mais baixo), onde foram obtidos os menores valores. Nas parcelas sem adubo verde (NPK e 2NPK) o teor de MO manteve-se intermediário com as demais espécies plantadas, possivelmente devido ao mato incidente mantido nestas parcelas $\mathrm{e}$ incorporados de forma semelhante às leguminosas. Dentro dos anos os valores de MO diminuiram de 19,5 para a $15,8 \mathrm{~g} / \mathrm{dm}^{3}$.

Teores maiores de $\mathbf{P}$ foram obtidos com o decorrer dos anos (de 4 para $8 \mathrm{md} / \mathrm{dm}^{3}$ ), porém entre os tratamentos não houve diferenças significativas, mesmo assim os valores foram considerados baixos pelo GRUPO PAULISTA (1994). Mesmos valores baixos foram encontrados para o $\mathrm{K}$, não apresentando diferenças significativas entre os tratamentos e anos.

Para o S ocorreu aumento significativo dos teores entre os anos, estando os valores em níveis altos conforme GRUPO PAULISTA (1994), porém não ocorrendo diferenças entre os tratamentos.

Os teores de $\mathrm{Ca}$ e $\mathrm{Mg}$, elevaram-se com os anos e apesar de não apresentar diferenças significativas entre os tratamentos, o solo das parcelas com Crotalaria juncea apresentaram maiores teores de $\mathrm{Ca}$. 
Houve um decréscimo dos teores de $\mathrm{H}+\mathrm{Al}$ (hidrogènio + alumínio) trocável, entre os anos, de 28,2 para $21,6 \mathrm{mmol}_{\mathrm{c}} / \mathrm{dm}^{3}$. Nas parcelas onde cultivouse as leguminosas são encontrados os maiores valores de $\mathrm{H}+\mathrm{Al}$.

Os valores de SB (soma de bases), T (CTC) e V\% (saturação por bases), apresentaram-se crescentes entre os anos, mas entre os tratamentos não houve diferença significativa ao nível de $5 \%$ de probabilidade pelo teste de Tukey.

$\mathrm{Na}$ Tabela 16, estão apresentados os resultados das características químicas do solo na profundidade de $20-40 \mathrm{~cm}$, relativo às entrelinhas de citros, isto é, ao local de cultivo das leguminosas, pode-se observar que a parcela com Crotalaria juncea apresentou, maior valor de $\mathrm{pH}$ apesar de não significativo. Os teores de MO, apresentam as mesmas tendências observadas na profundidade de 0 $20 \mathrm{~cm}$.

Para o P não observa-se diferenças significativas entre os anos, porém, os teores nas parcelas com mucuna preta encontram-se com valores muito altos em relação aos demais tratamentos. Acréscimo nos teores de $\mathrm{S}$ entre os anos, foram observados, mas não ocorreu diferença entre os tratamentos. Nas camadas de sub-superficie $(20-40 \mathrm{~cm})$ os teores de $\mathrm{S}$ são bem maiores que o da superficie $(0-20 \mathrm{~cm})$, indicando lixiviação do $\mathrm{SO}_{4}{ }^{-}$para as camadas mais inferiores.

Os tratamentos não influenciaram significativamente nos teores de $\mathrm{K}$ do solo.

A Crotalaria juncea e a mucuna preta, apresentam teores superiores de $\mathrm{Ca}$ quando comparados aos demais tratamentos. É importante lembrar que o tratamento com Crotalaria juncea, em ambas profundidades, apresenta valores significativamente superiores para os teores de $\mathrm{MO}$, bem como, de $\mathrm{Ca}$, concordando com os valores obtidos por VITTI et al. (1979) 


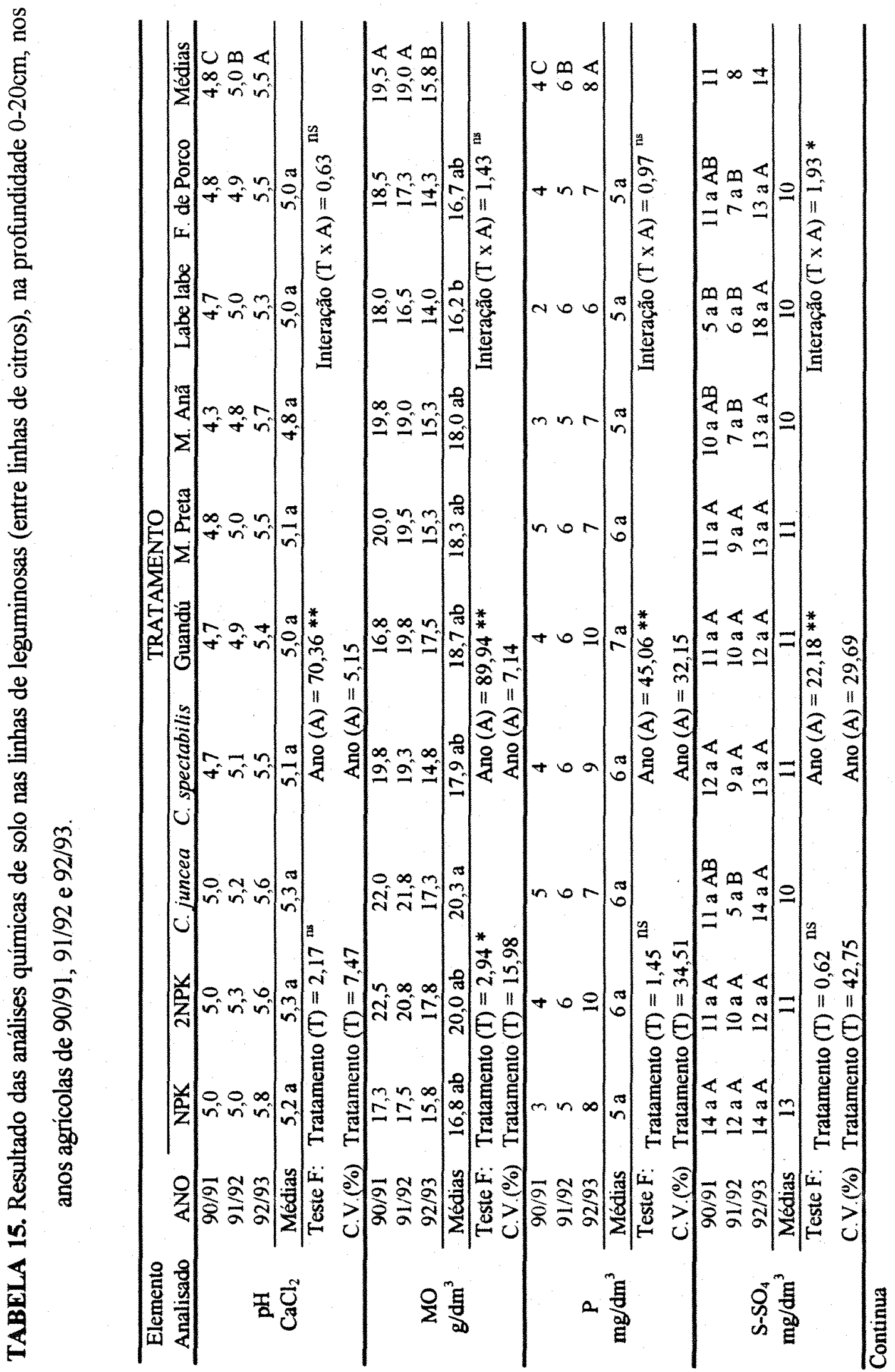




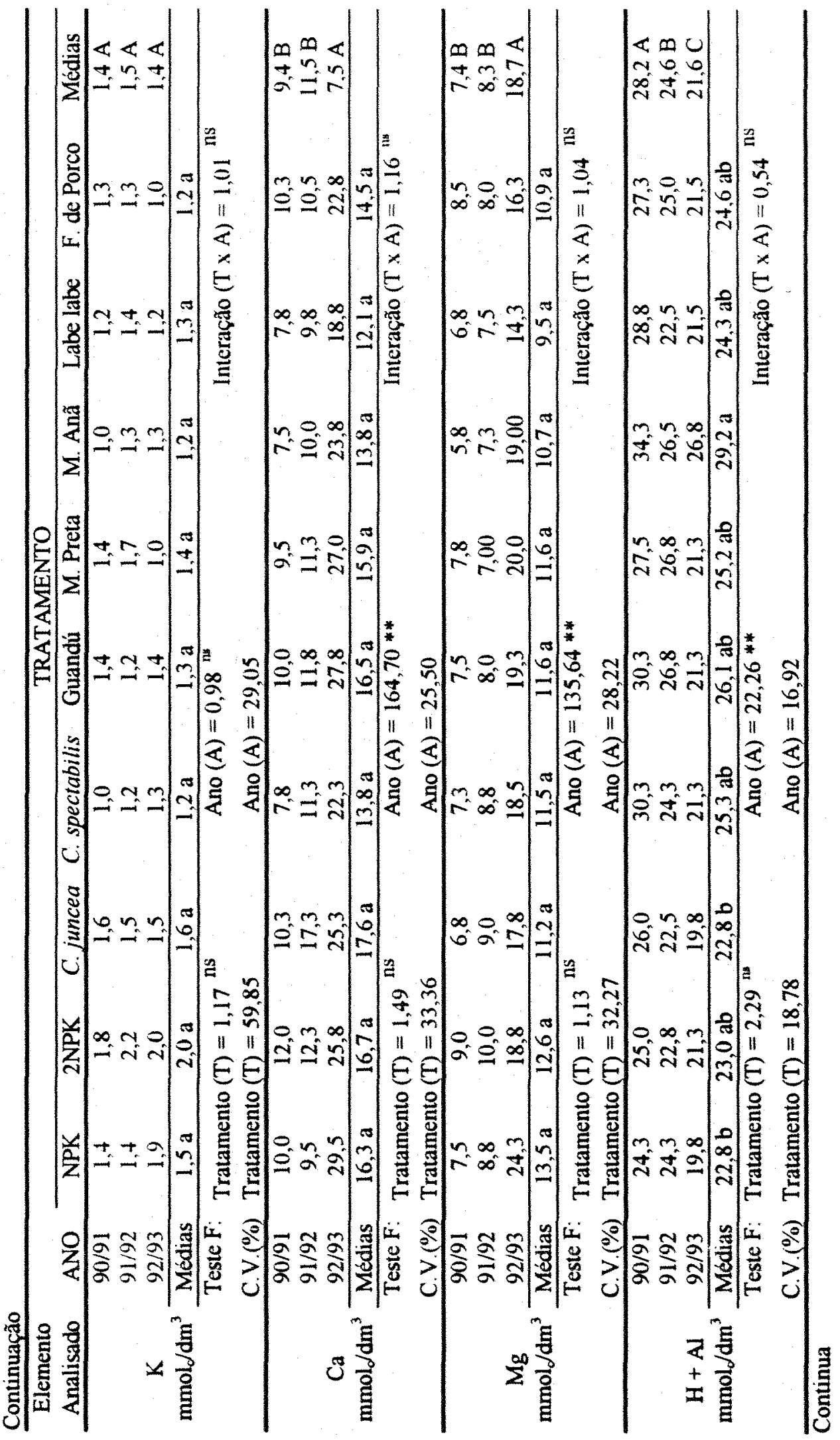




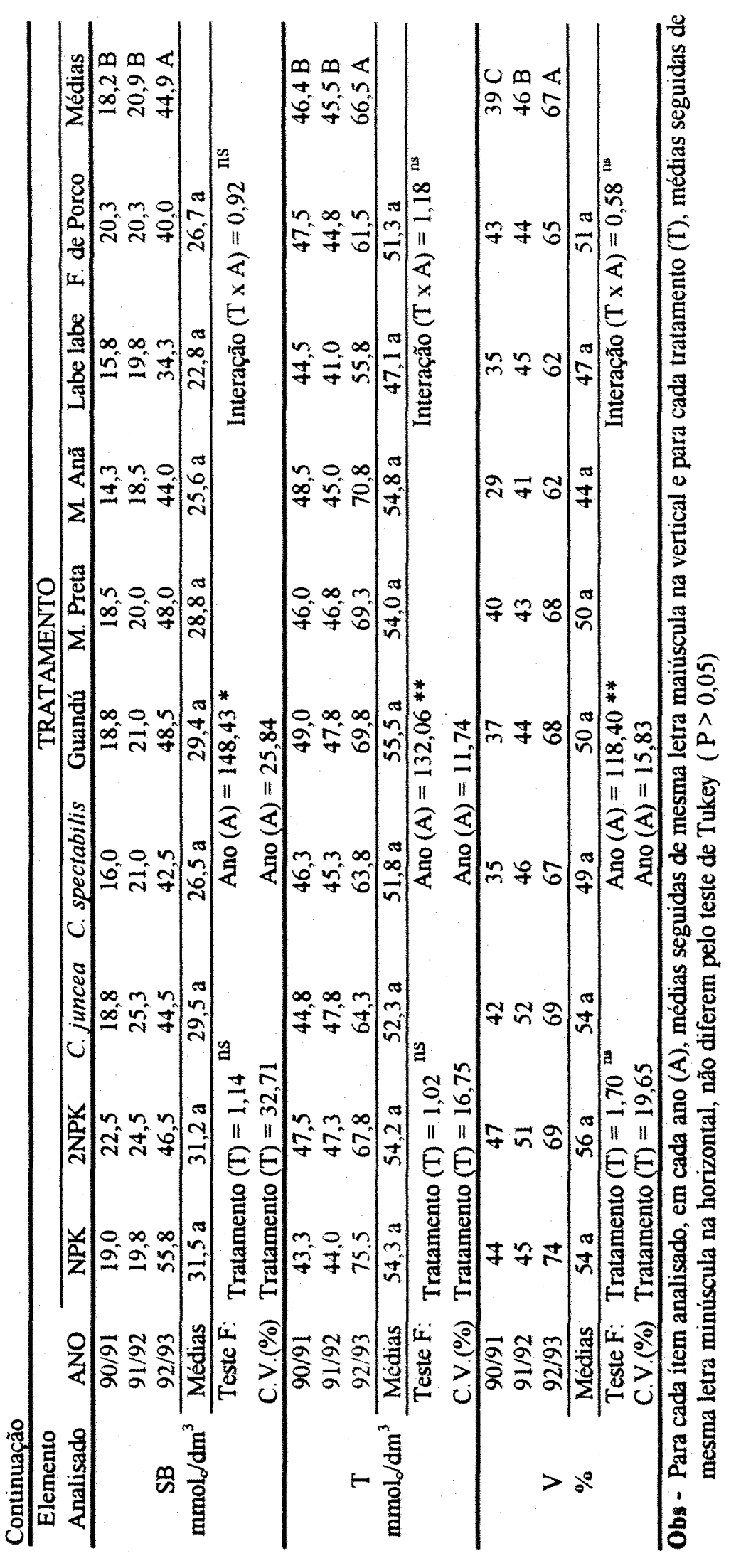




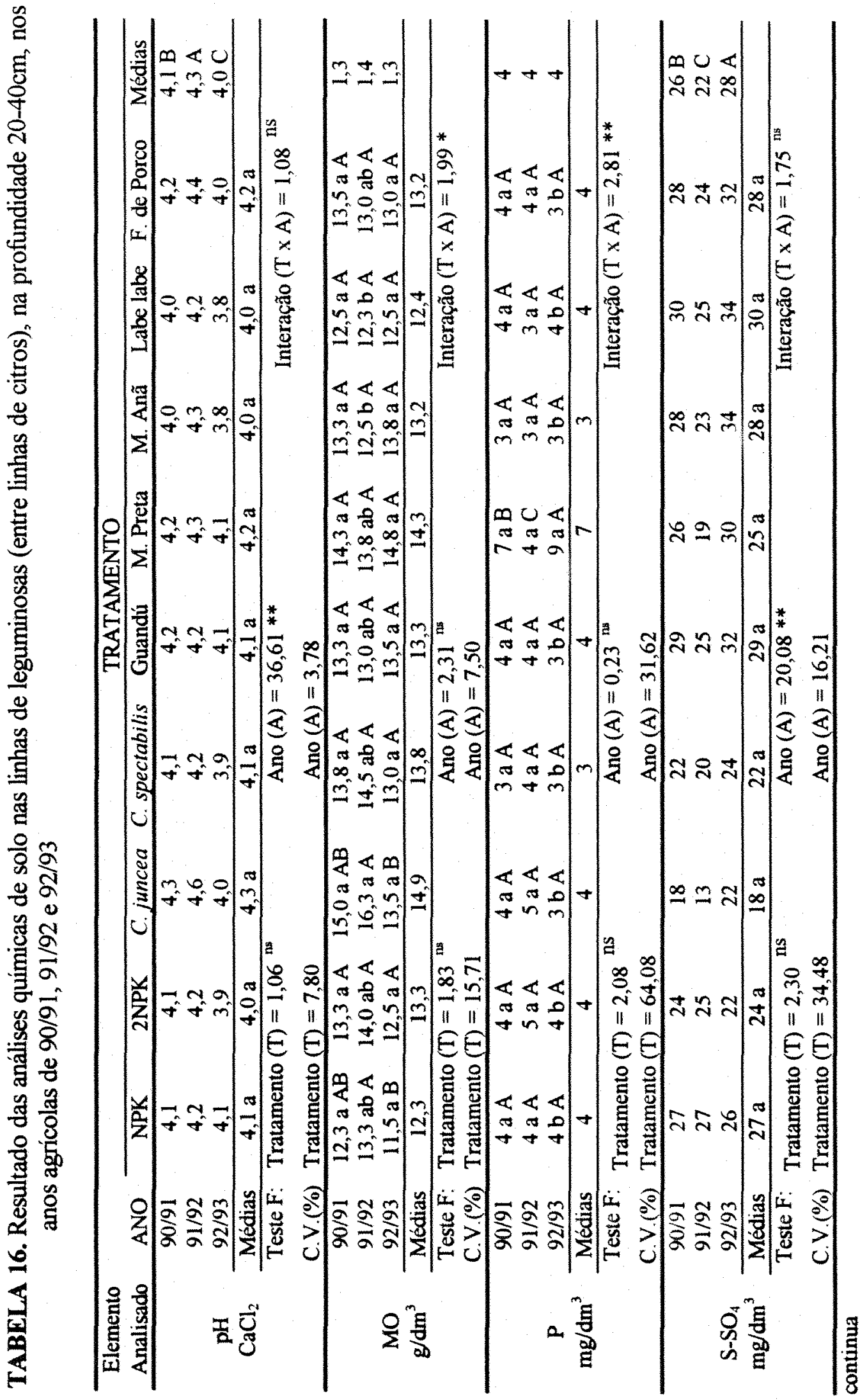




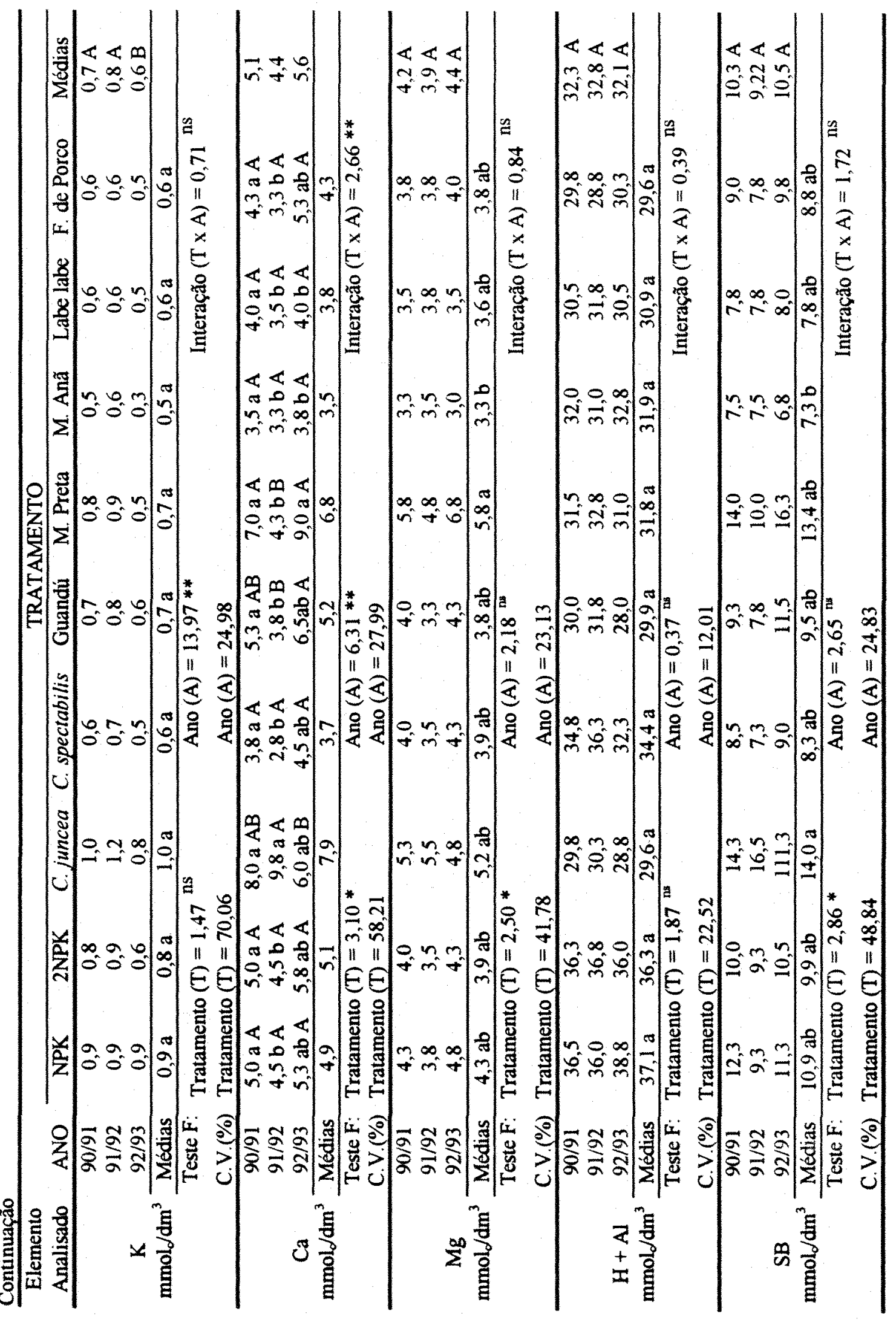




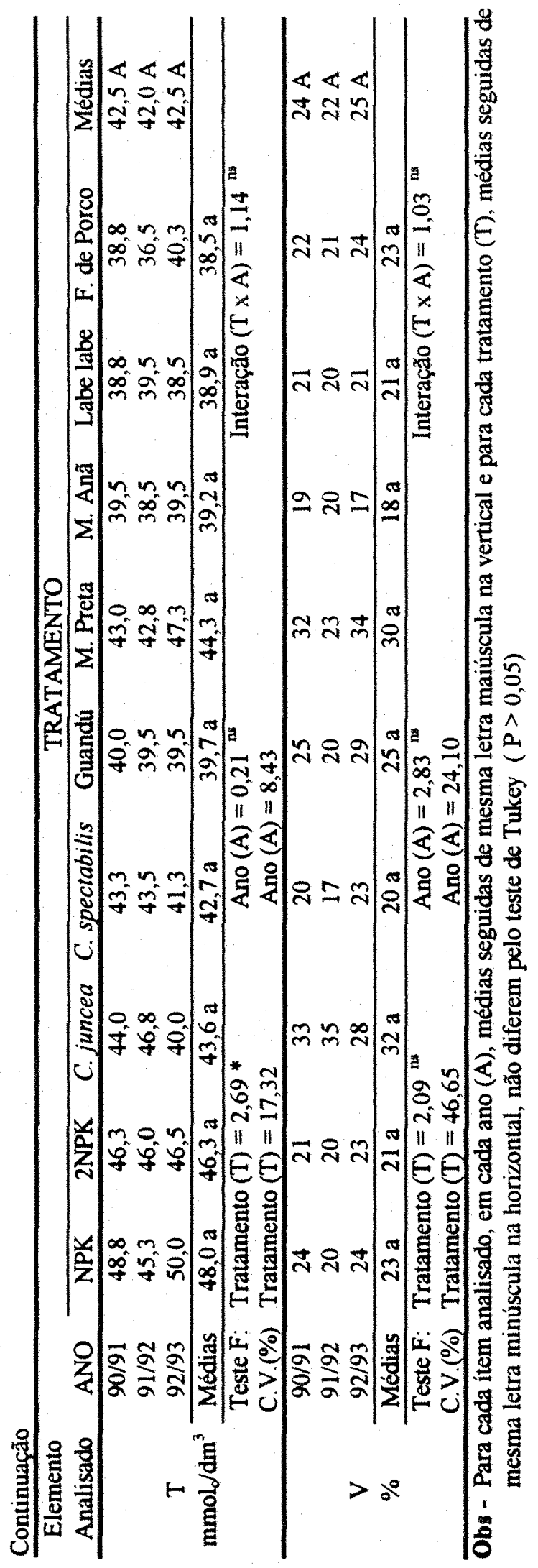


Valores superiores significativamente de $\mathrm{Mg}$ foi encontrado nas parcelas com mucuna preta e menores com a mucuna anã. Entre os anos não ocorreu diferenças significativas.

Novamente, a Crotalaria juncea se destacou apresentando valores superiores estatisticamente de SB, ficando com os menores valores a mucuna anã. Quanto ao $\mathrm{T}$ e $\mathrm{V} \%$, os mesmos não apresentaram diferenças significativas entre os tratamentos e anos.

Resumindo, os efeitos em características químicas do solo em amostras retiradas na entrelinha do citros, antes da semeadura anual dos adubos verdes, evidenciaram que o tratamento com Crotalaria juncea foi mais efetivo no aumento dos teores de MO, cálcio e de soma de bases do solo, bem como os tratamentos com adubação verde apresentaram maiores teores de $\mathrm{H}+\mathrm{Al}$.

\subsubsection{Análise química do solo retirado na entrelinha de citros, após incor- poração anual dos adubos verdes}

Após a corte anual das leguminosas nas parcelas foram efetuadas amostragem do solo para determinação das propriedades químicas, sendo as mesmas retiradas aos 90 e 180 dias da primeira (no dia da incorporação).

Quando se compara os três resultados das amostragens para análise química de solo do experimento em questão, ou seja, as amostras coletadas no dia do corte (Tabela 17, amostragem 1); três meses após (Tabela 18, amostragem 2) e aos seis meses (Tabela 19, amostragem 3), verifica-se que para o pH, nas parcelas com Crotalaria juncea, são encontrados os maiores valores, em torno de 5,3 e para a mucuna anã, os menores valores, em torno de 4,9. $\mathrm{Na}$ amostragem 2, não existiu diferença significativa entre os tratamentos, mas sim acidificação do solo com o passar dos anos, oque não ocorreu nas amostra 1 e 3 que apresentaram para os anos, elevação de pH. Já na amostragem 3, verificou-se maiores valores significativos de $\mathrm{pH}$ para o tratamento 2NPK. 
Ao analisar-se os teores de $\mathrm{MO}$, observou-se que na amostragems 1 , houve queda dos teores de matéria orgânica no último ano e, entre tratamentos somente no primeiro ano observou-se diferenças significativa. Novamente, os menores teores são apresentados pela mucuna anã e os maiores pelo tratamento 2NPK e Crotalária juncea. Já na amostragem 2, ocorre aumento dos teores de MO com os anos e, entre tratamentos, os maiores teores são para o 2NPK e Crotalaria juncea e menores para a mucuna anã. Aos seis meses (180 dias) os teores com os anos se mantiveram e entre os tratamentos, o $2 \mathrm{NPK}$ apresenta significativamente maior teor $\operatorname{com} 22,9 \mathrm{~g} / \mathrm{dm}^{3}$ e, para o labe labe o menor $\left(18,7 \mathrm{~g} / \mathrm{dm}^{3}\right)$. Como o mato nos tratamentos NPK e 2NPK não foi roçado durante a condução do experimento, é possivel que tenha funcionado como adubo verde mantendo os teores de MO de igual a superior aos tratamentos com leguminosas.

Para $P$, as amostragens aos 0,90 e 180 dias após a incorporação mostraram que houve aumento dos teores de $\mathrm{P}$ com os anos e apresentou apenas uma pequena redução significativa nos tratamentos sem leguminosas aos 180 dias. Conforme padrões de fertilidade estabelecidos pelo GRUPO PAULISTA (1994), os teores de P encontram-se baixos, ou seja entre 6 e $12 \mathrm{mg} / \mathrm{dm}^{3}$.

Os teores de $\mathrm{S}$, foram considerados altos $\left(>10 \mathrm{mg} / \mathrm{dm}^{3}\right)$ pelo GRUPO PAULISTA (1994), sem diferenças significativas entre os tratamentos na amostragem 1 e aumento dos teores de $\mathrm{S}$ no solo no ano agricola 92/93 (amostragem 2). Na terceira amostragem o S foi analisado somente em 91/92 e 92/93, mostrando redução no segundo ano com diferença significativa entre tratamentos (maior teor para o labe labe e menor para o 2NPK).

$\mathrm{O}$ cátion $\mathrm{K}$ não mostrou diferença significativa nos tratamentos, ocorrendo pequenas diferenças entre os anos na amostragens 2 e 3 . Em média as amostras classificam-se segundo GRUPO PAULISTA (1994) de baixo $\left(0,8\right.$ a $\left.1,5 \mathrm{mmol} / \mathrm{dm}^{3}\right)$ a médio $\left(1,6\right.$ a $\left.3,0 \mathrm{mmol}_{d} / \mathrm{dm}^{3}\right)$.

Os cátions $\mathrm{Ca}$ e $\mathrm{Mg}$, apresentaram algumas diferenças significativas durante a condução do experimento, porém o mais marcante foi o aumento gradativo de seus teores no solo, na época de corte em direção ao sexto mês após esta operação. Verificou-se também a evolução dos teores com o passar dos anos. 
Conforme o GRUPO PAULISTA (1994), os teores de Mg, enquadraramse nas classes de teores considerados altos $\left(>8 \mathrm{mmol}_{\mathrm{c}} / \mathrm{dm}^{3}\right)$, já o $\mathrm{Ca}$ encontra-se com relação $\mathrm{Ca} / \mathrm{Mg}$ em torno de $1 / 1$, quando o recomendado seria de $3 / 1$. Mesmo assim, os tratamentos com Crotalaria juncea apresentaram os maiores teores de $\mathrm{Ca}$.

$\mathrm{OH}+\mathrm{Al}$, nas médias das amostragens na época de corte, apresentou no tratamento com Crotalaria juncea, os maiores valores e para a mucuna anã os menores. Quando se avaliou a terceira amostragem, esta ordem se inverteu completamente.

Como era de se esperar após avaliar o comportamento dos cátions, observou que a SB e o $T$, também aumentaram seus valores, gradativamente, da amostragem na época do corte em direção a amostragem no sexto mês após o corte.

O V\% ou saturação por bases encontra-se na classe de teores considerados médios pelo GRUPO PAULISTA (1994).

Quanto aos micronutrientes avaliados no solo $\mathrm{B}, \mathrm{Cu}, \mathrm{Fe}, \mathrm{Mn}$ e $\mathrm{Zn}$, os resultados de amostragem evidenciaram oscilações em seus teores, quando comparados entre os tratamentos, anos e épocas de amostragens. Conforme o GRUPO PAULISTA (1994), o $\mathrm{Cu}$ apresentou valores na classe média $\left(0,3\right.$ a $\left.1,0 \mathrm{mg} / \mathrm{dm}^{3}\right)$, passando para a classe alta $\left(>1,0, \mathrm{mg} / \mathrm{dm}^{3}\right)$. Os micronutrientes $(\mathrm{B}, \mathrm{Mn}$ e $\mathrm{Zn})$, apresentaram valores muito superiores aos considerados altos e citados pelo GRUPO PAULISTA (1994), ou seja, B $\left(>0,60 \mathrm{mg} / \mathrm{dm}^{3}\right), \mathrm{Mn}\left(>5,0 \mathrm{mg} / \mathrm{dm}^{3}\right)$ e $\mathrm{Zn}\left(>1,5 \mathrm{mg} / \mathrm{dm}^{3}\right)$.

Novamente observou-se nas amostras retiradas na entrelinha, em diferentes épocas após a incorporação das leguminosas ou do próprio mato nas parcelas com adubação mineral, pequenas variações entre as características químicas do solo, porém o tratamento com Crotalaria juncea voltou à apresentar os maiores teores de $\mathrm{Ca}$, SB e V\%. 


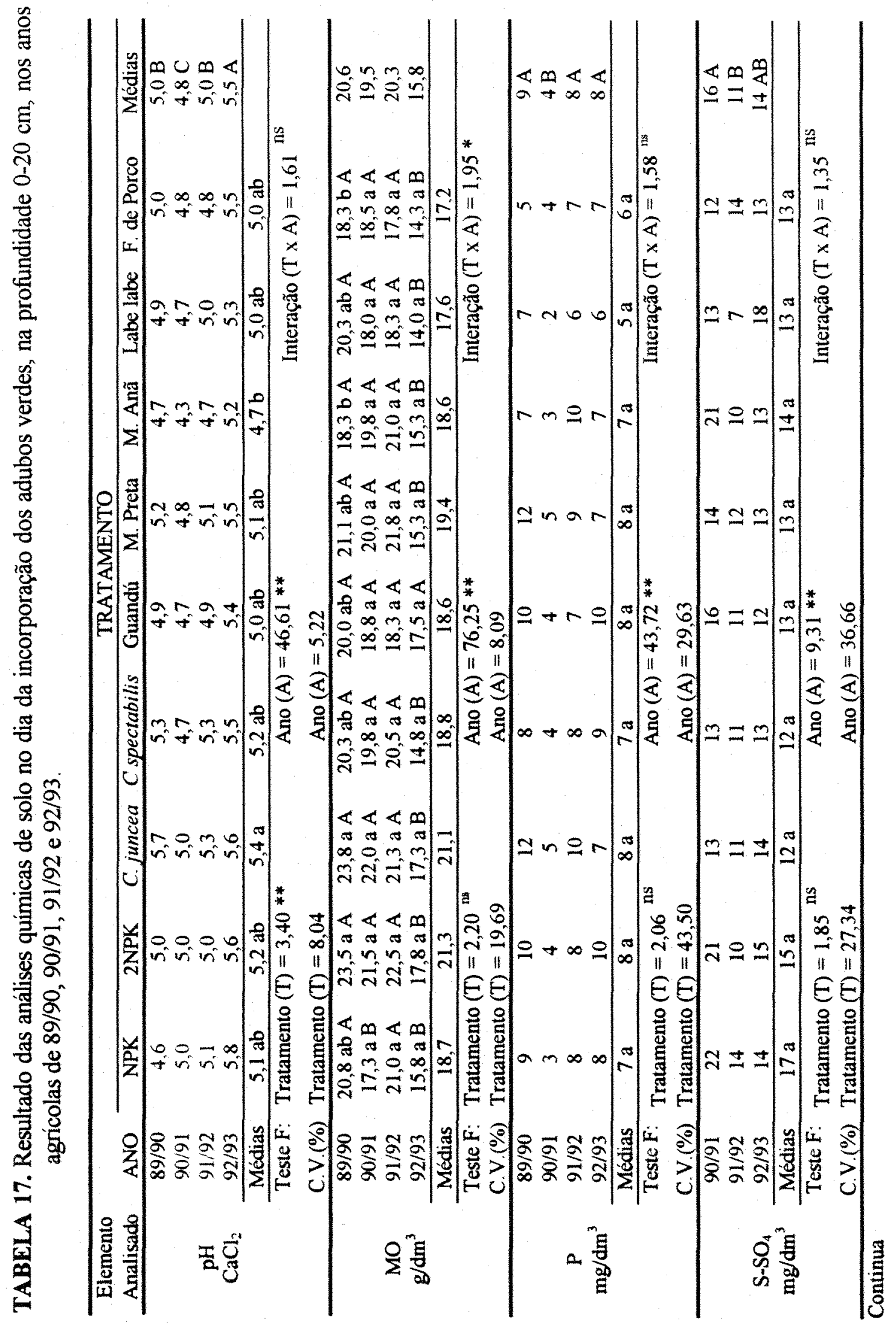




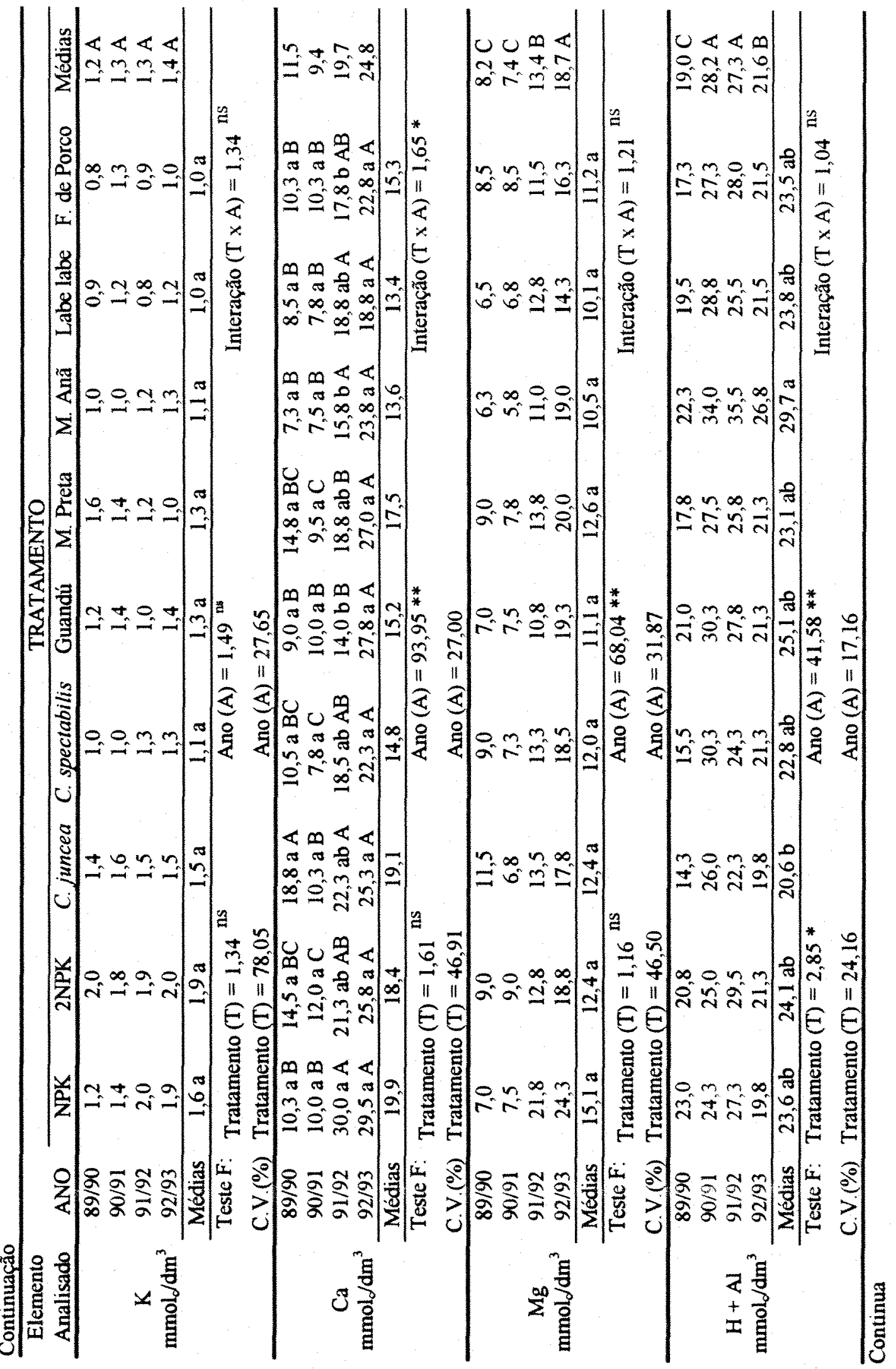




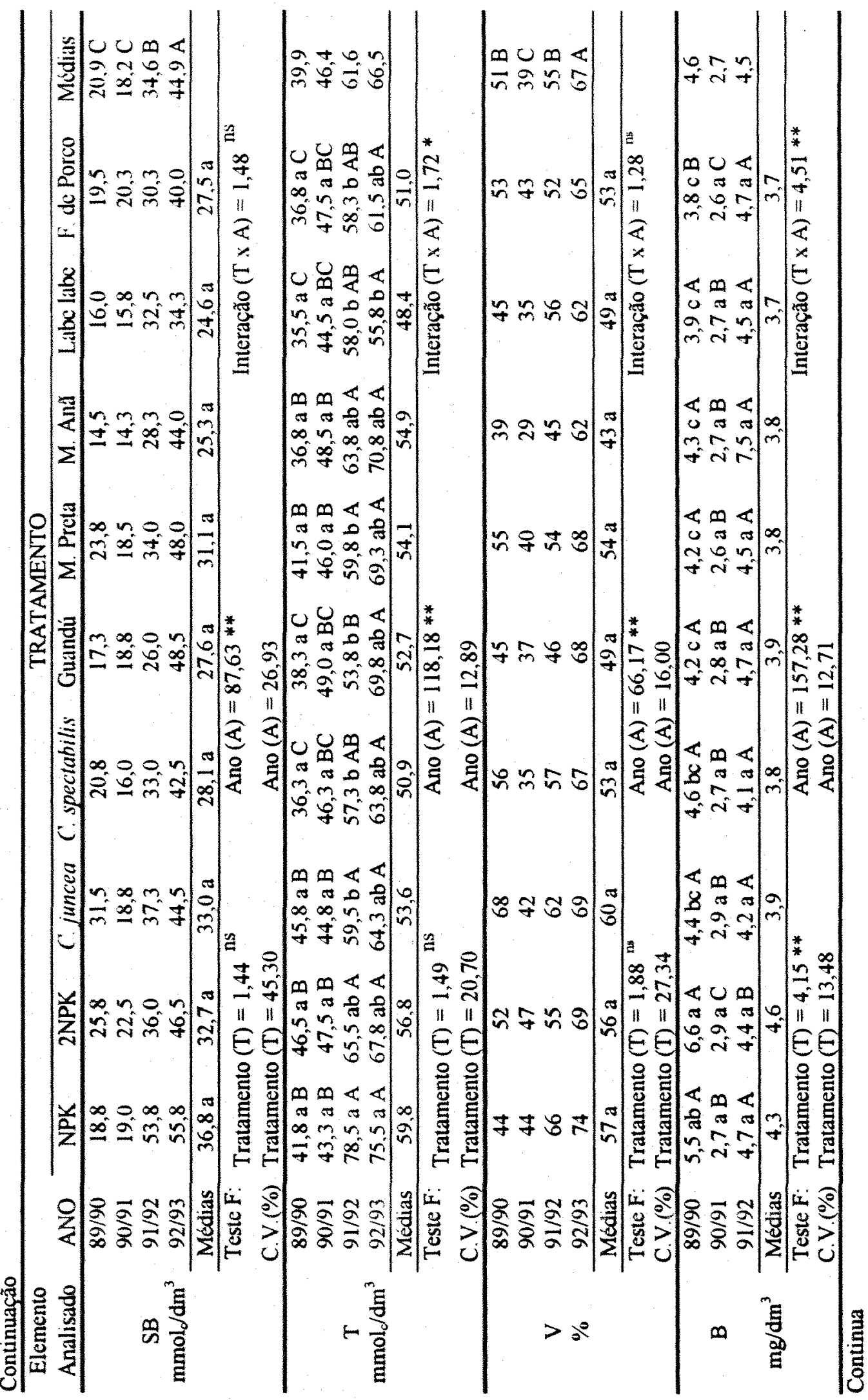




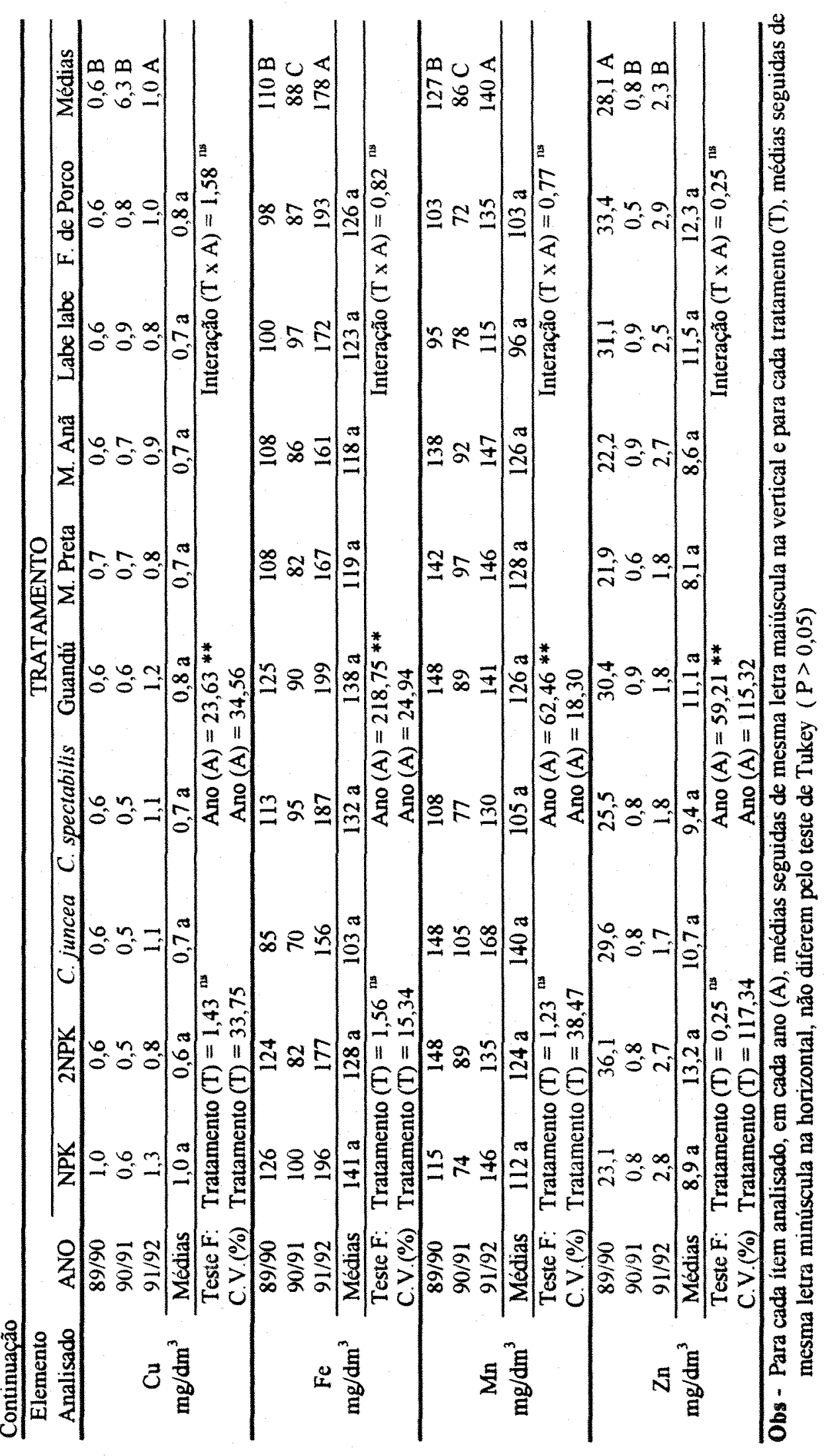




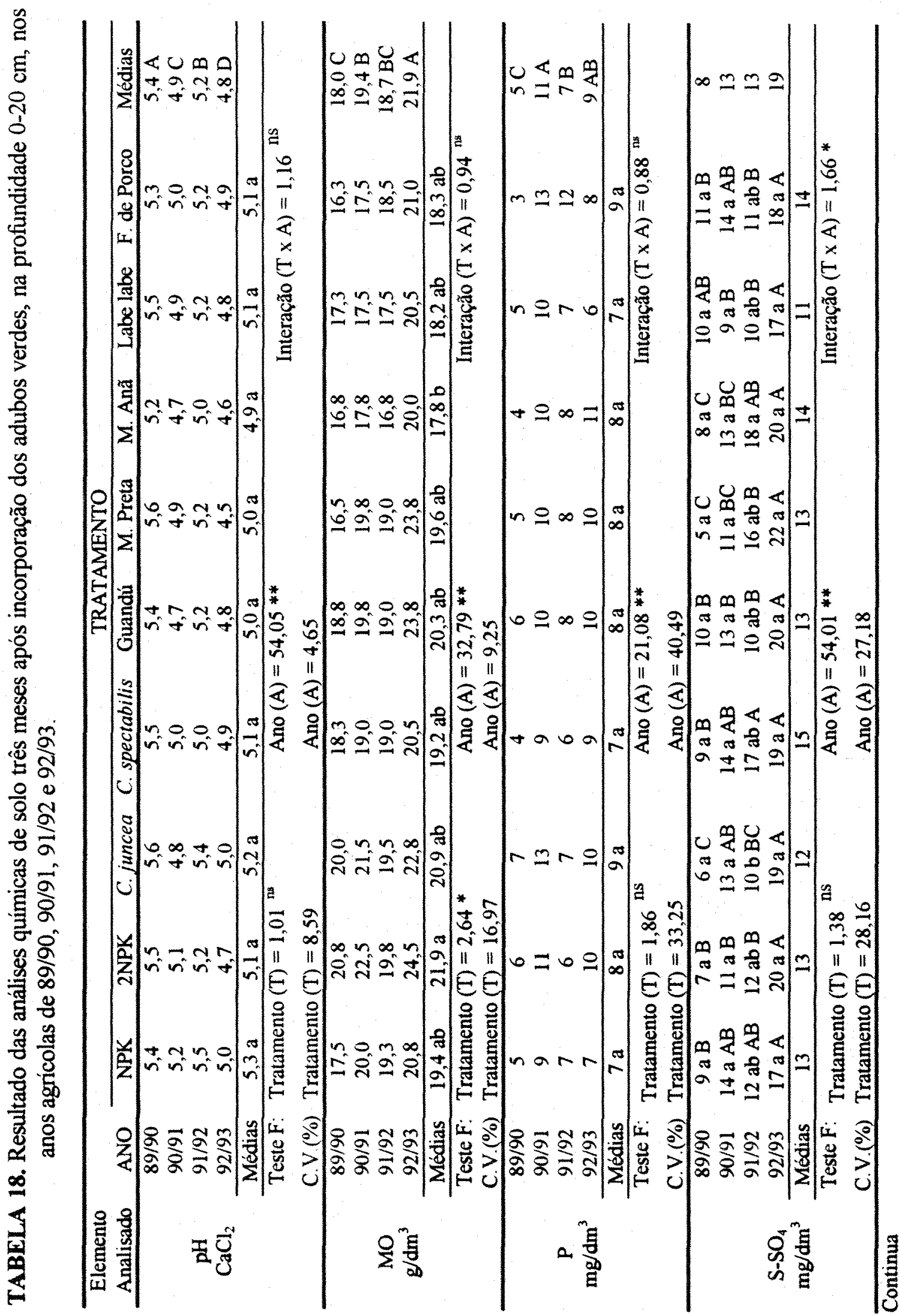




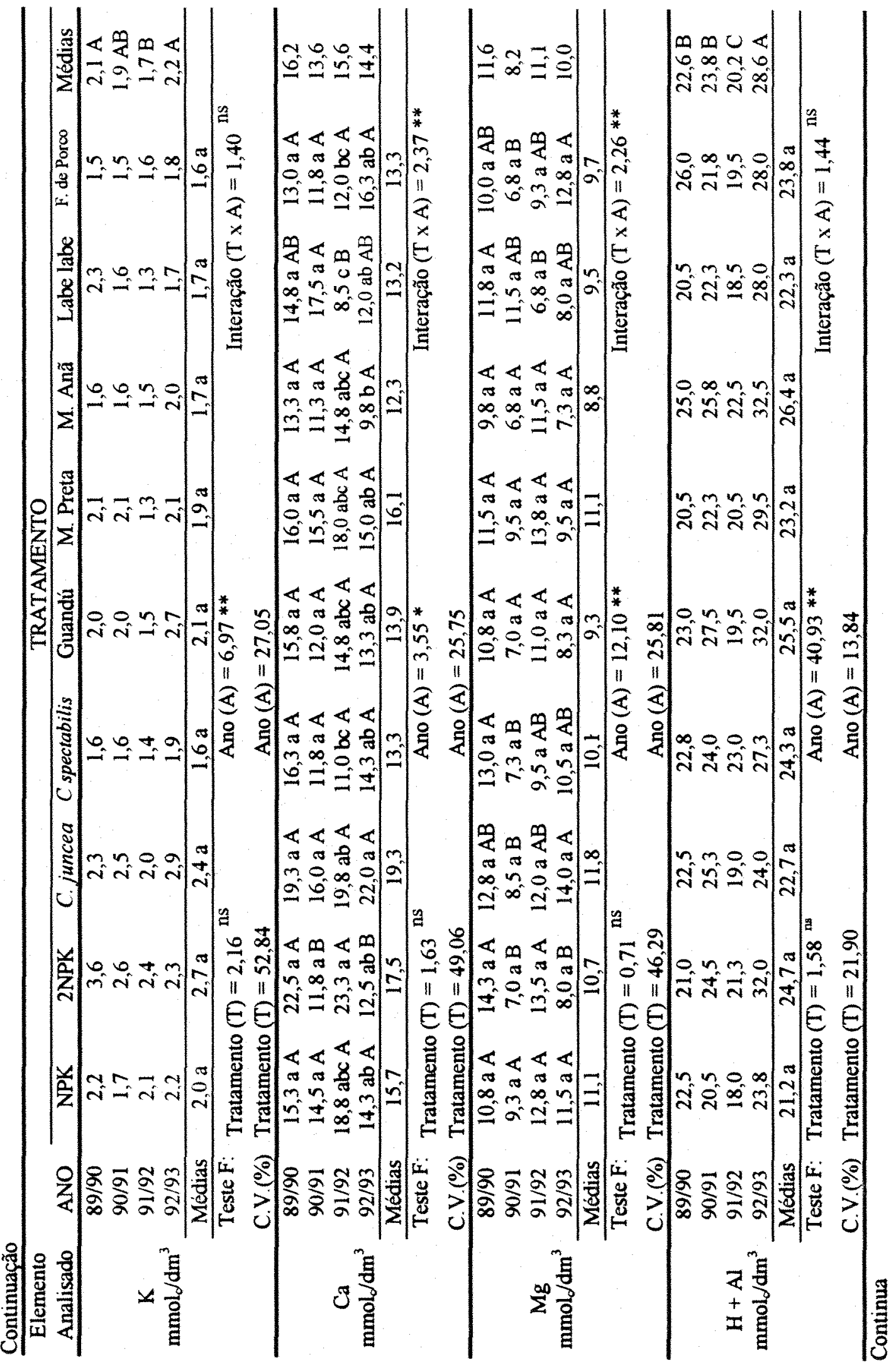




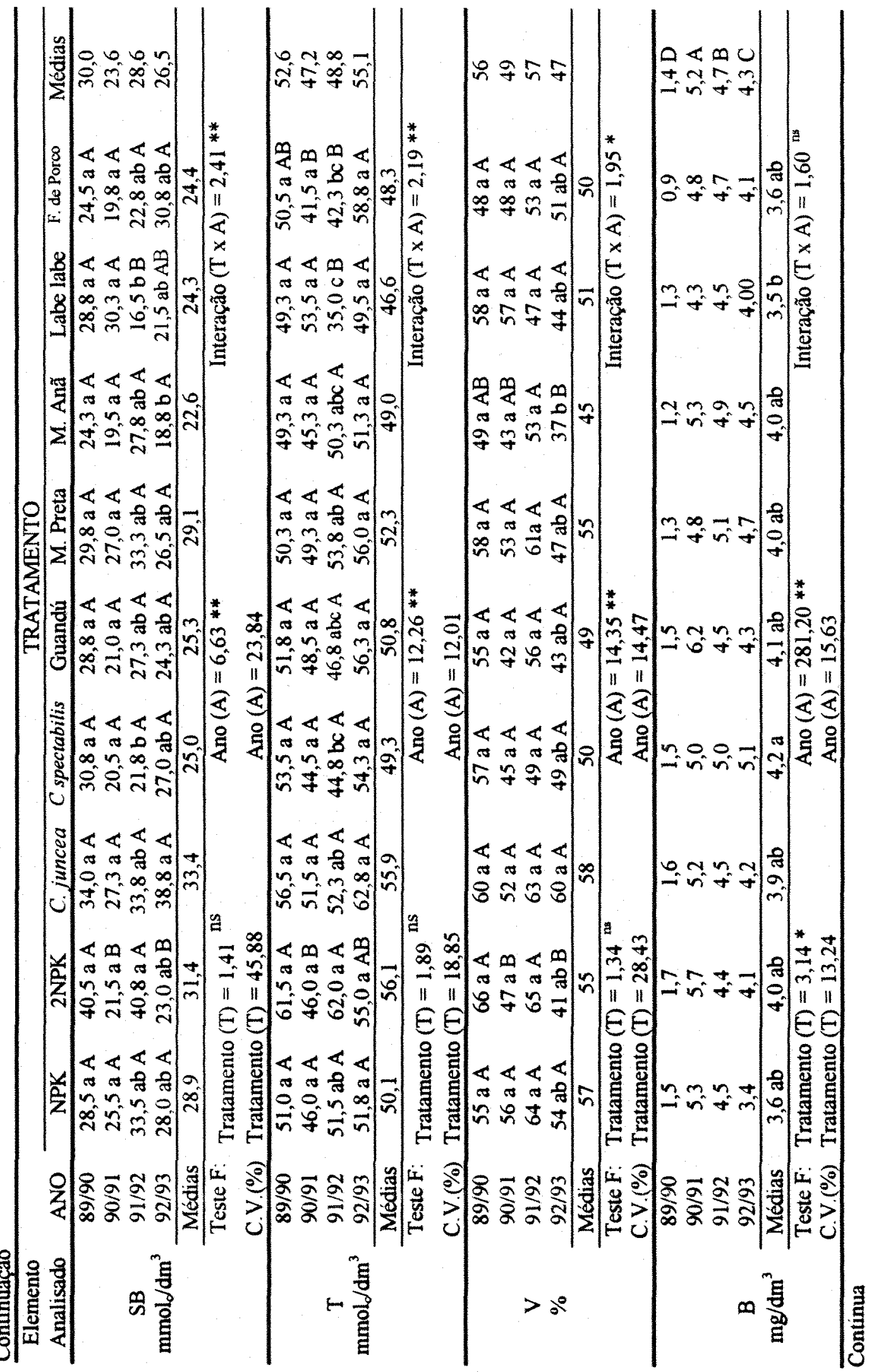




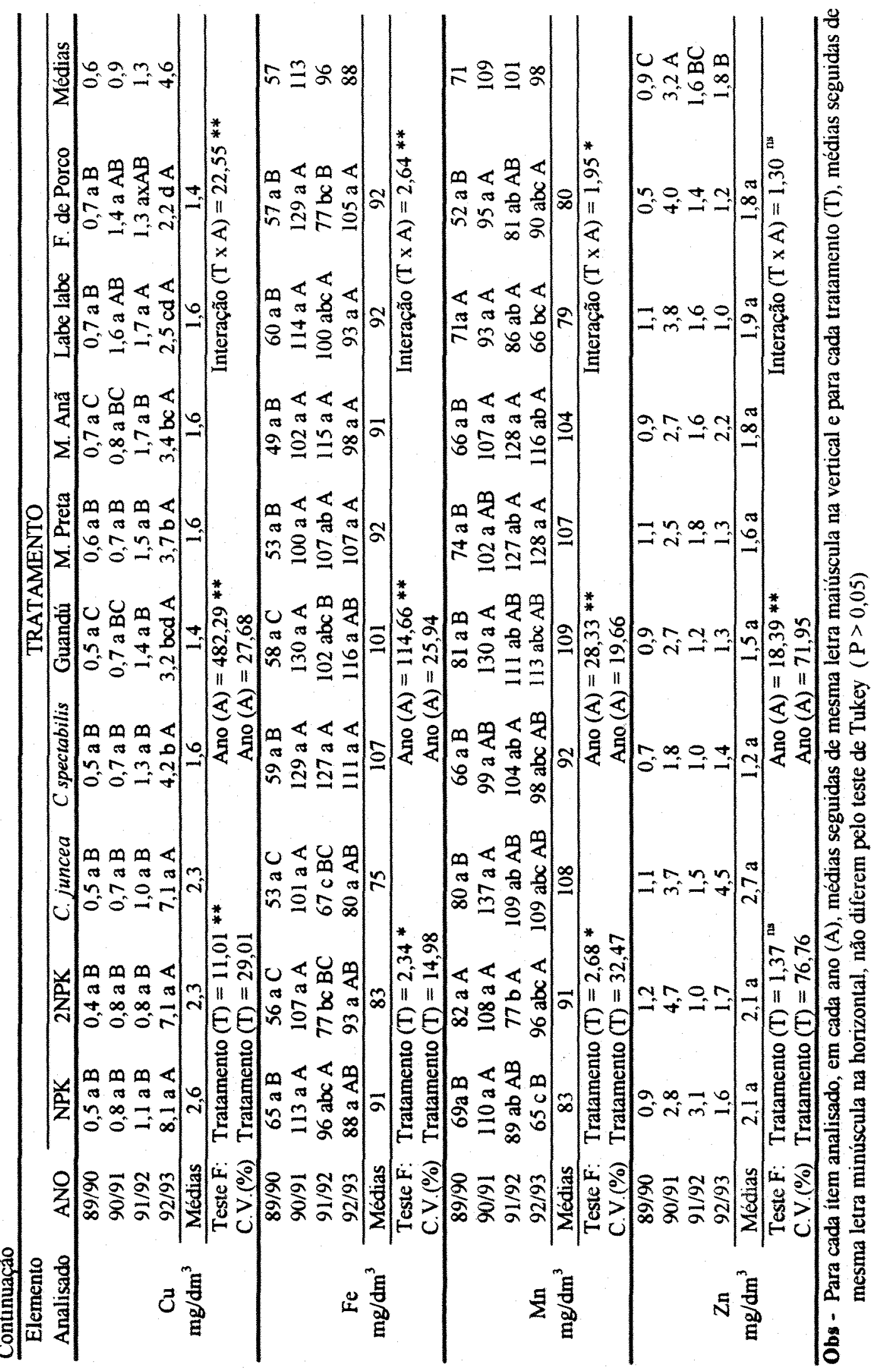




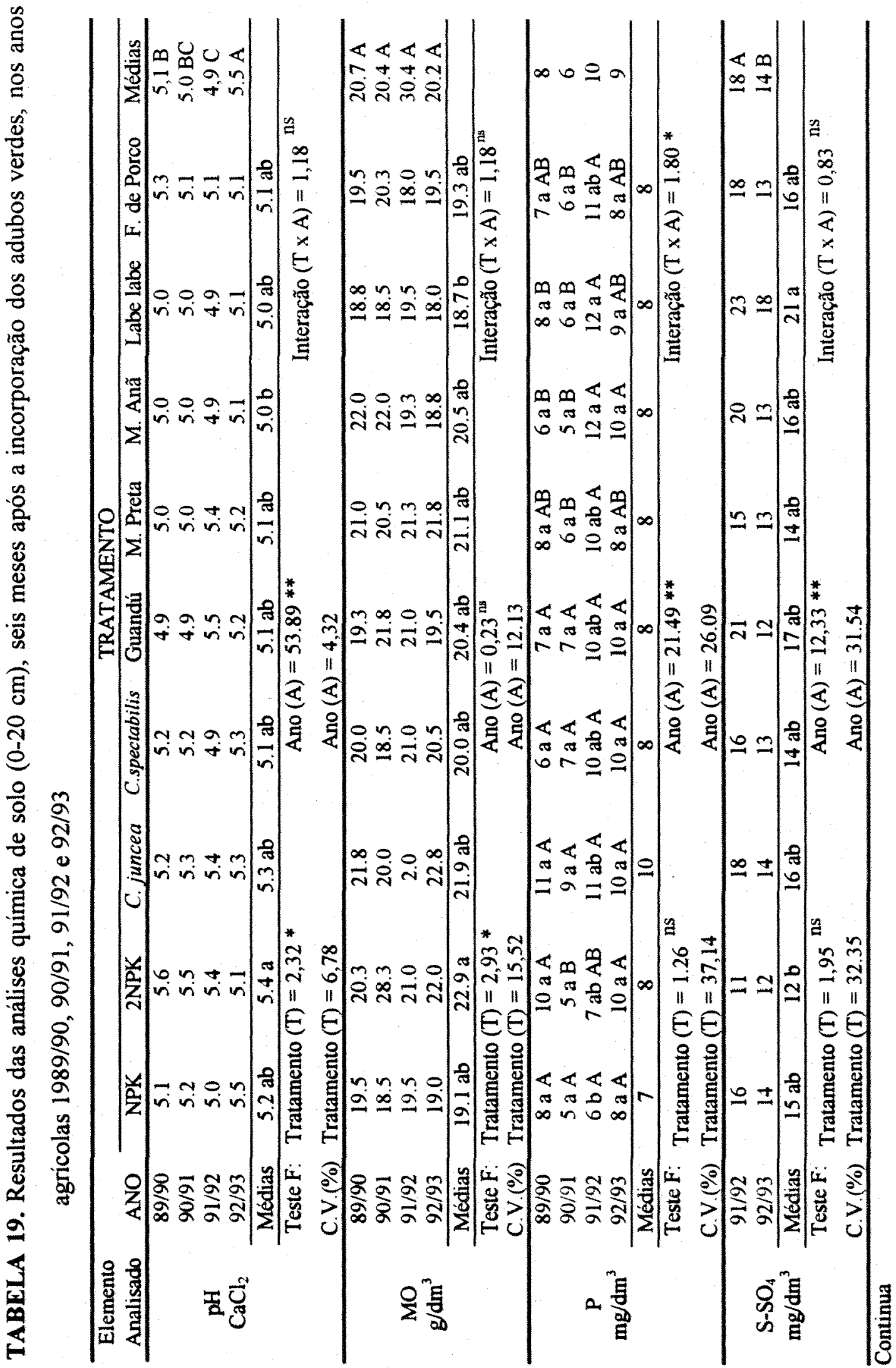




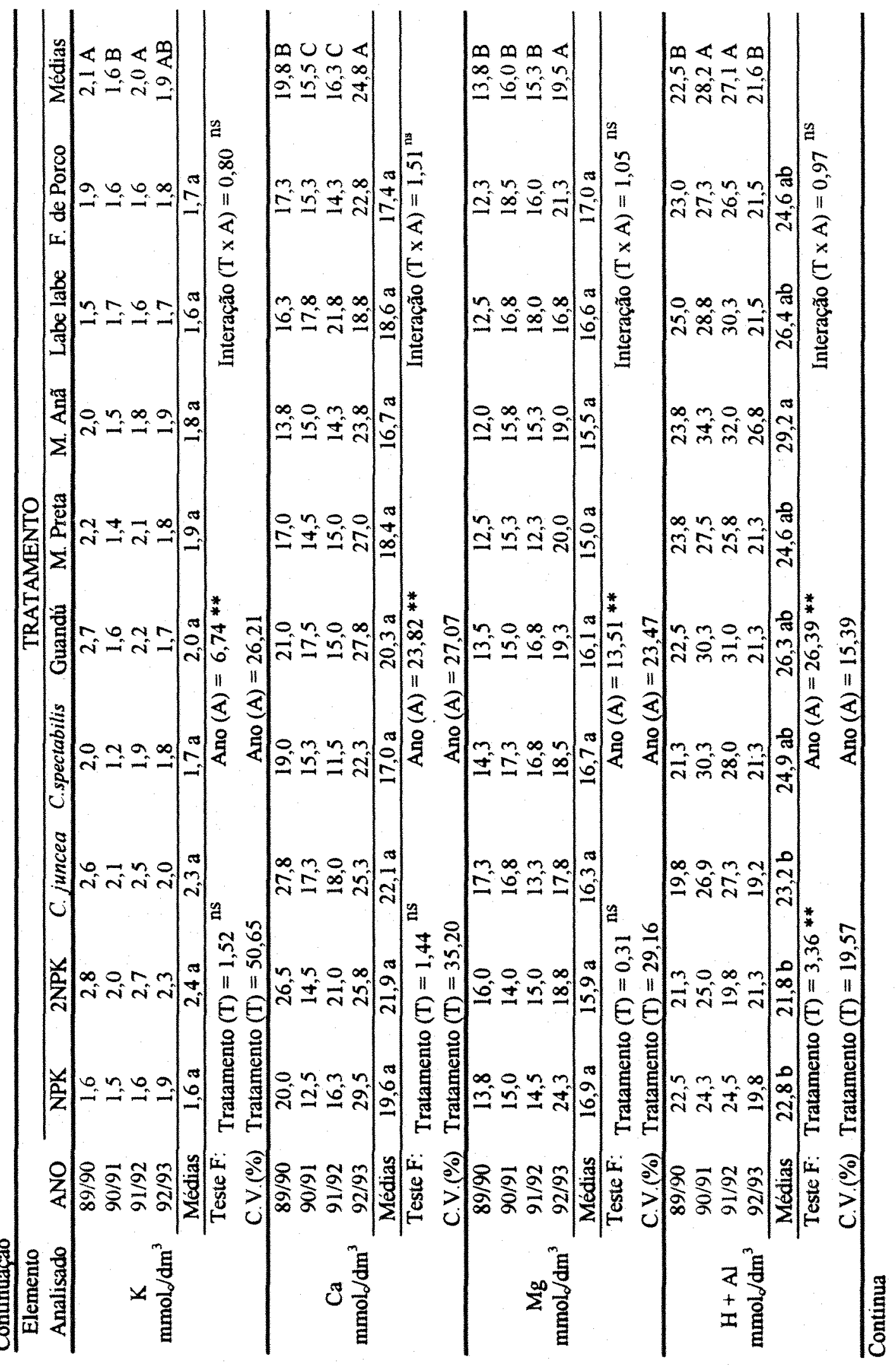




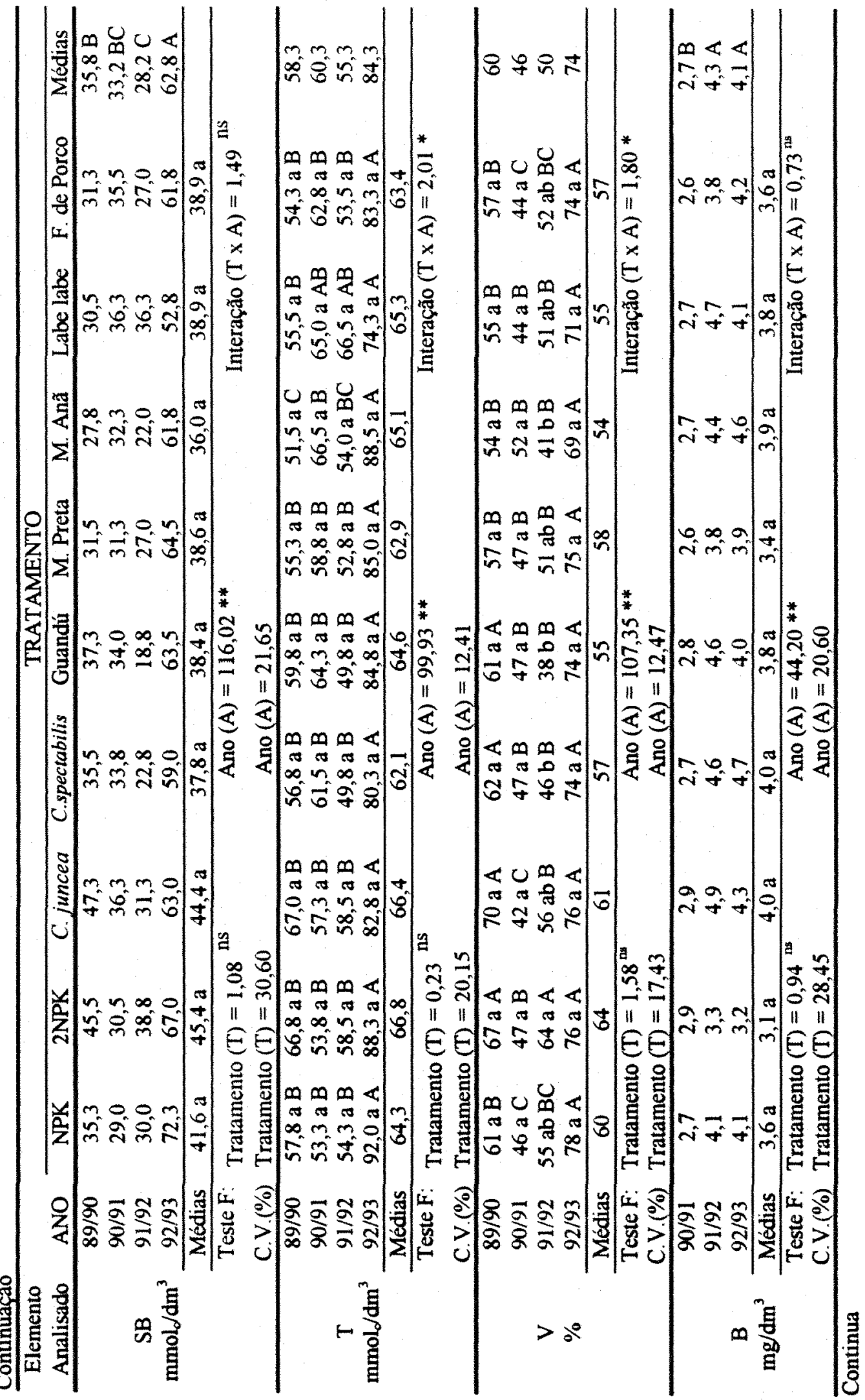




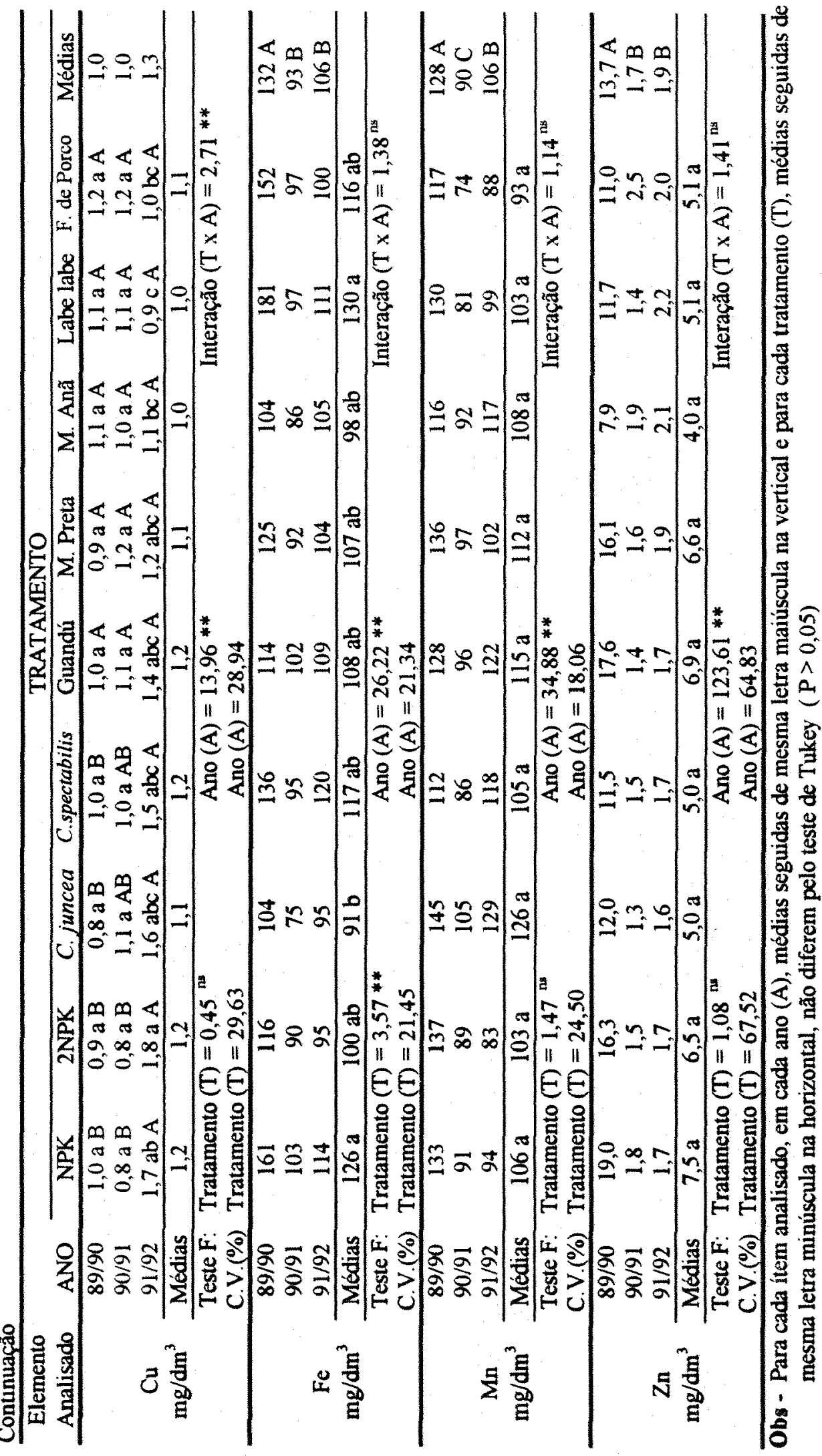




\section{8. - Produção de fitomassa}

Os resultados de produção de fitomassa verde, porcentagem de umidade e material seco das leguminosas, estão apresentadas na Tabela 20, considerando a semeadura em área total, ou seja, não apenas na área intercalar. Como o espaçamento entre as linhas de citros em questão foi de 7,0 metros e o plantio foi feito na faixa central de 3,5 metros, os valores da Tabela 8, devem ser dividido por 2, ou seja, deve-se considerar o plantio em $50 \%$ da área. Pode-se concluir que em quatro anos de cultivos consecutivos de leguminosas intercalares ao citros, ocorreram alterações na quantidade de fitomassa produzida, variando a produção com a época de incorporação e condições climáticas (regime de chuva, principalmente). A partir do segundo ano a produção de material elevou-se, significativamente, de 16 para 30 t/ha. No ano agrícola de $90 / 91$, as plantas foram roçadas após 148 dias da semeadura, ao contrário dos demais anos que a incorporação deu-se aproximadamente aos 110 dias. Por esta razão verificou-se o maior peso de material verde neste ano agrícola. No entanto, quando analisou-se a porcentagem de umidade neste ano, verificou-se que as espécies consideradas de ciclo curto como a Crotalaria spectabilis e a mucuna anã, principalmente, apresentaram menores porcentagem de umidade. A Crotalaria juncea se destacou na produção de material vegetal, seguida pelo feijão de porco e pelo guandú, que foi incorporado sem ter atingido a época de florescimento. Se esta espécie fosse conduzida por mais tempo ou até o florescimento, provavelmente teria aumentado a produção de fitomassa. A mucuna anã no segundo ano, por ser de ciclo precoce, suscetivel a cercosporiose e ter sido incorporada aos 148 dias da semeadura, teve seus valores de peso vegetal bastante prejudicado, pois devido aos motivos citados, grande parte das folhas já estavam incorporadas ao solo. Estes dados mostraram, como era de se esperar, que as espécies de hábito de crescimento rasteiro, apresentaram maior teor de água e, por isso, considera-se que tenham consistência mais tenra com maior porcentagem de água em sua composição. Quando foi avaliado o peso do material seco, observou-se que o feijão de porco, perdeu o segundo lugar em produção de material para o guandú, ficando na terceira posição. 
Tem-se portanto, a seguinte ordem decrescente de produção de matéria seca: Crotalaria juncea $>$ guandú $>$ feijão de porco $>$ mucuna preta $>$ mucuna anã $>$ labe labe $>$ Crotalaria spectabilis . Esses dados indicaram a melhor performance na produção de fitomassa da Crotalaria juncea, inclusive no cultivo intercalar na cultura de citros, concordando com os dados obtidos por: IAPAR, (1984); AZEREDO \& MANHÃES, (1983) e KIEHL, (1959).

Quando as espécies plantadas foram comparadas estatisticamente, dentro de cada ano, quanto ao material verde, porcentagem de umidade e material seco, estas apresentam diferenças significativas ao nível de $5 \%$ de probabilidade, pelo teste de Tukey.

Considerando a produção de fitomassa verde, equivalente em área total, obteve-se para a Crotalaria juncea a produção média nos quatro anos de 41,39 t/ha, semelhante ao citado em IAPAR (1984), que considera que em média, a produção varia de 16 a 54 t/ha de material verde e de 10 a 16 t/ha de matéria seca. Estes valores, também concordam ao citado por AZEREDO \& MANHÃES (1983), que estima a produção média de 28 a 62 t/ha A produção de 29,73 t/ha foi conseguida por KIEHL (1959), demonstrando que os valores médios observados estão dentro das médias de produtividade esperados. Estatisticamente esta espécie diferiu das demais quanto a produção de material verde e seco (t/ha). É importante salientar que nas parcelas com esta espécie a incidência de plantas daninhas foi mínima.

A produção de material verde da Crotalaria spectabilis segundo AZEREDO \& MANHÃES (1983), deve ser de 16 a 32 t/ha, no entanto, foi obtido na E.E.C.B. a média de 12,79 t/ha, estando assim aquém dos valores citados acima. Estatisticamente esta espécie apresentou os menores valores em relação as demais, no tocante a material verde e $\operatorname{seco}(\mathrm{t} / \mathrm{ha})$.

O guandú, produziu em média, nos quatro anos, $28,97 \mathrm{t} /$ ha de material verde, dentro dos valores apresentados por AZEREDO \& MANHÃES (1983), que estima a produção de fitomassa entre 23 e 33 t/ha. Esta espécie também desempenhou importante papel no controle das plantas daninhas, apresentando baixíssima incidência. 
A mucuna preta produziu, em média, nos quatro anos, 18,54 t/ha. Estes valores estão abaixo dos estabelecidos por AZEREDO \& MANHÃES (1983), que são da ordem de 26 a 42 t/ha. Esta espécie destacou-se como protetora do solo e mostrou-se eficiente no controle de plantas daninhas. $\mathrm{O}$ único inconveniente desta espécie é o hábito trepador que possui, devendo portanto, ser manejada.

A mucuna anã produziu, em média, nos quatro anos, 18,64 t/ha, valores estes dentro dos níveis apresentados por AZEREDO \& MANHÃES (1983) que são da ordem de 17 a 35t/ha. Esta produção baixa de fitomassa, ocorreu mesmo sob severa infecção de cercosporiose, desde sua emergência, que reduziu sua germinação e sobrevivência e promoveu a queda de folhas das remanescentes, levando a uma maior incidência de plantas daninhas nestas parcelas, interferindo no seu desenvolvimento e produção.

O labe labe, produziu, em média, nos quatro anos, $18,17 \mathrm{t} / \mathrm{ha}$ de material verde, valores estes também dentro da faixa de produção estimada por AZEREDO \& MANHÃES (1983). Esta planta de hábito rasteiro, cobre bem o solo, demonstrando sua ação protetora do solo e controladora de plantas daninhas. Deve-se ficar atento após o início do florescimento, pois apartir dai, elas desempenham o hábito trepador.

O feijão de porco, produziu, na média, dos quatro anos, 30,24 t/ha e segundo AZEREDO \& MANHÃES (1983), a média esperada é de 10 a $23 \mathrm{t} / \mathrm{ha}$, estando os valores obtidos em nível superior aos citados. Esta espécie apesar de sua altura não ultrapassar 1 metro, produz uma quantidade de fitomassa aproximada das espécies de porte alto como o guandú e a Crotalaria juncea que chegaram a uma altura superior a 2 metros e apresentava, na época de incorporação, vagens bastante pesadas.

Analisando os dados de produção de fitomassa verificou-se que a Crotalaria juncea, foi o tratamento que apresentou maiores produções de material vegetal (seco e úmido), ficando num segundo grupo o guandú e o feijão de porco.

As Fotos 9 e 10, ilustram o corte dos adubos verdes de porte rasteiro e herbáceo, respectivamente, com o auxilio de roçadeira acoplada ao trator. 


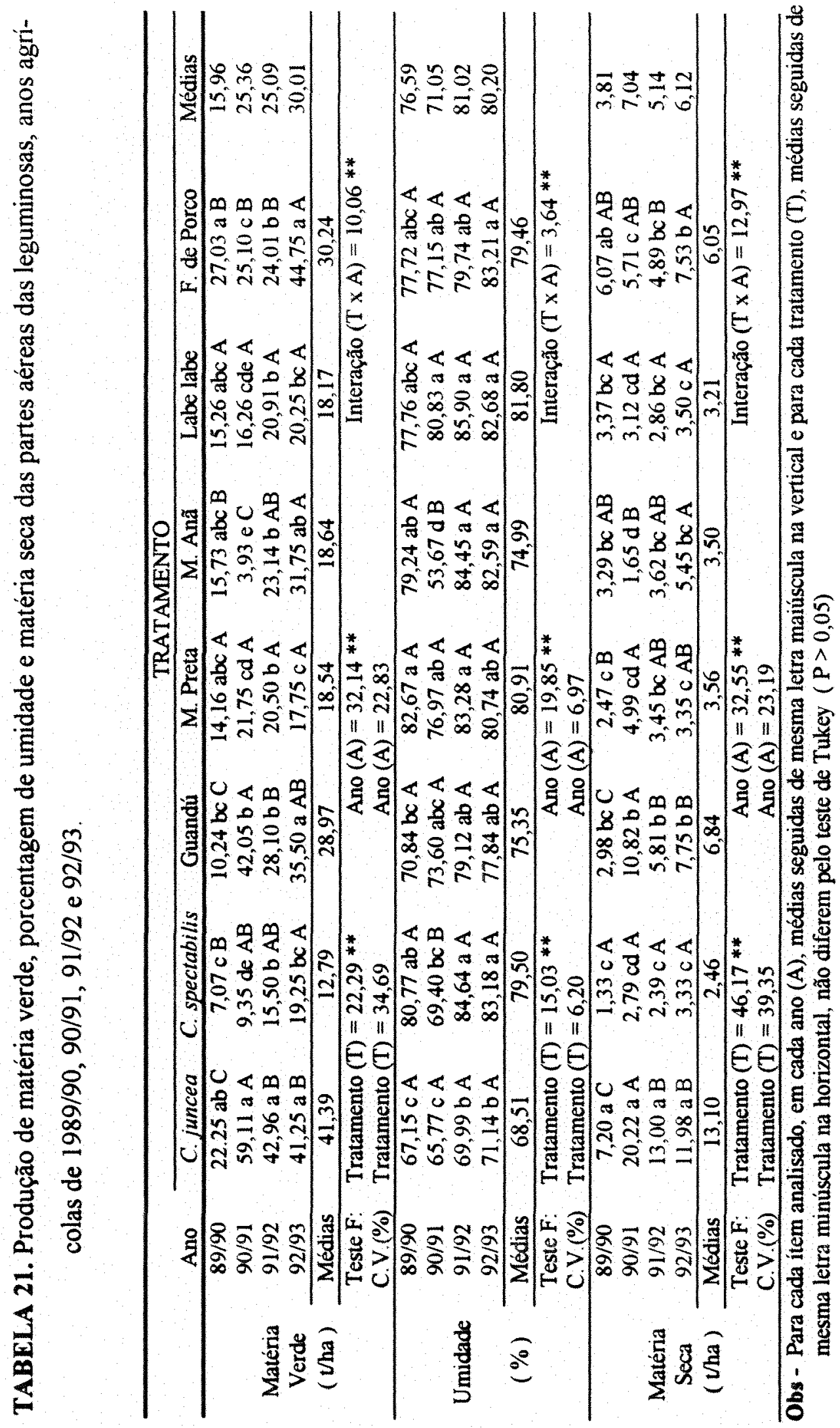




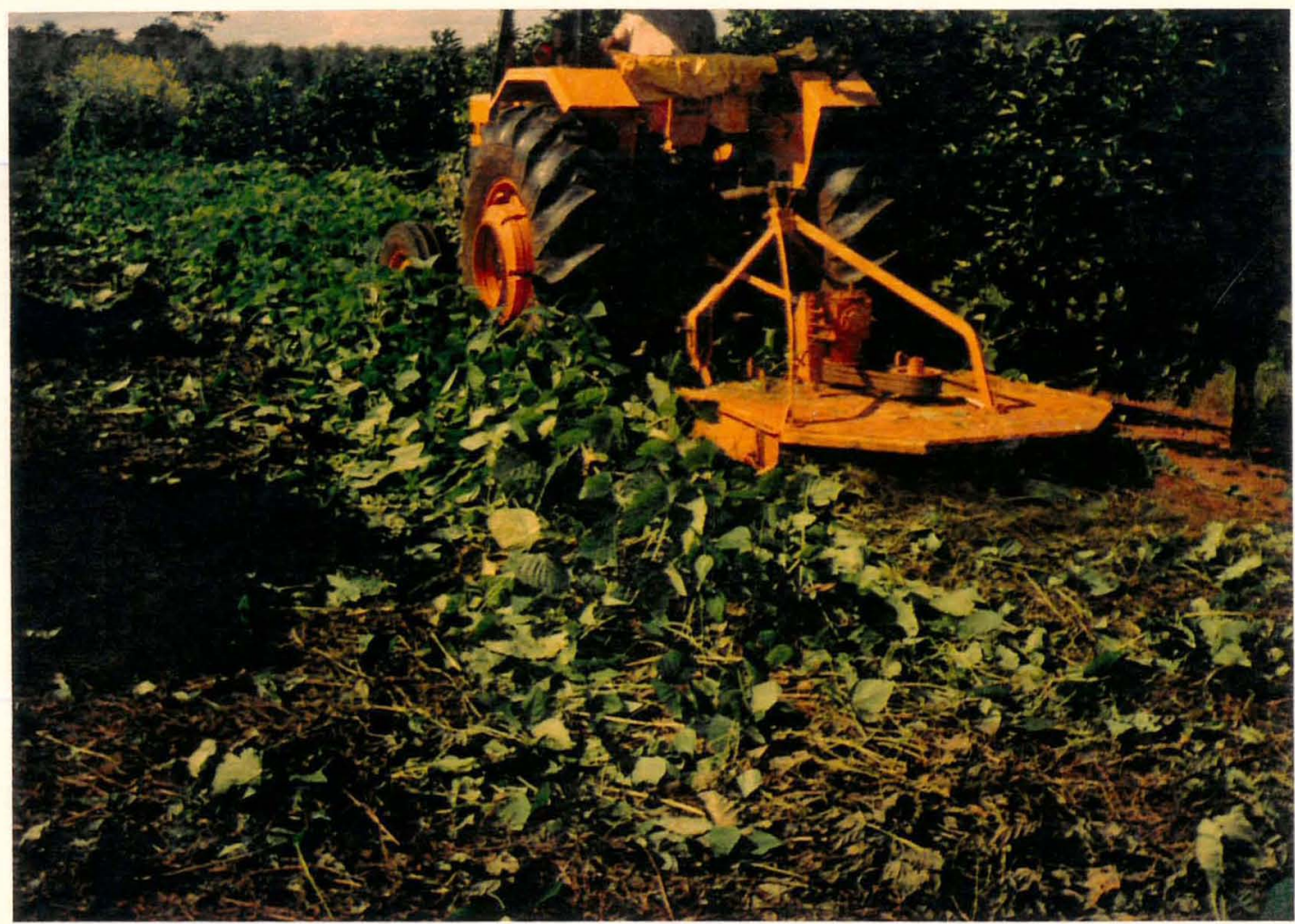

FOTO 9. Aspectos do corte com roçadeira de adubo verde de porte rasteiro (mucuna preta)

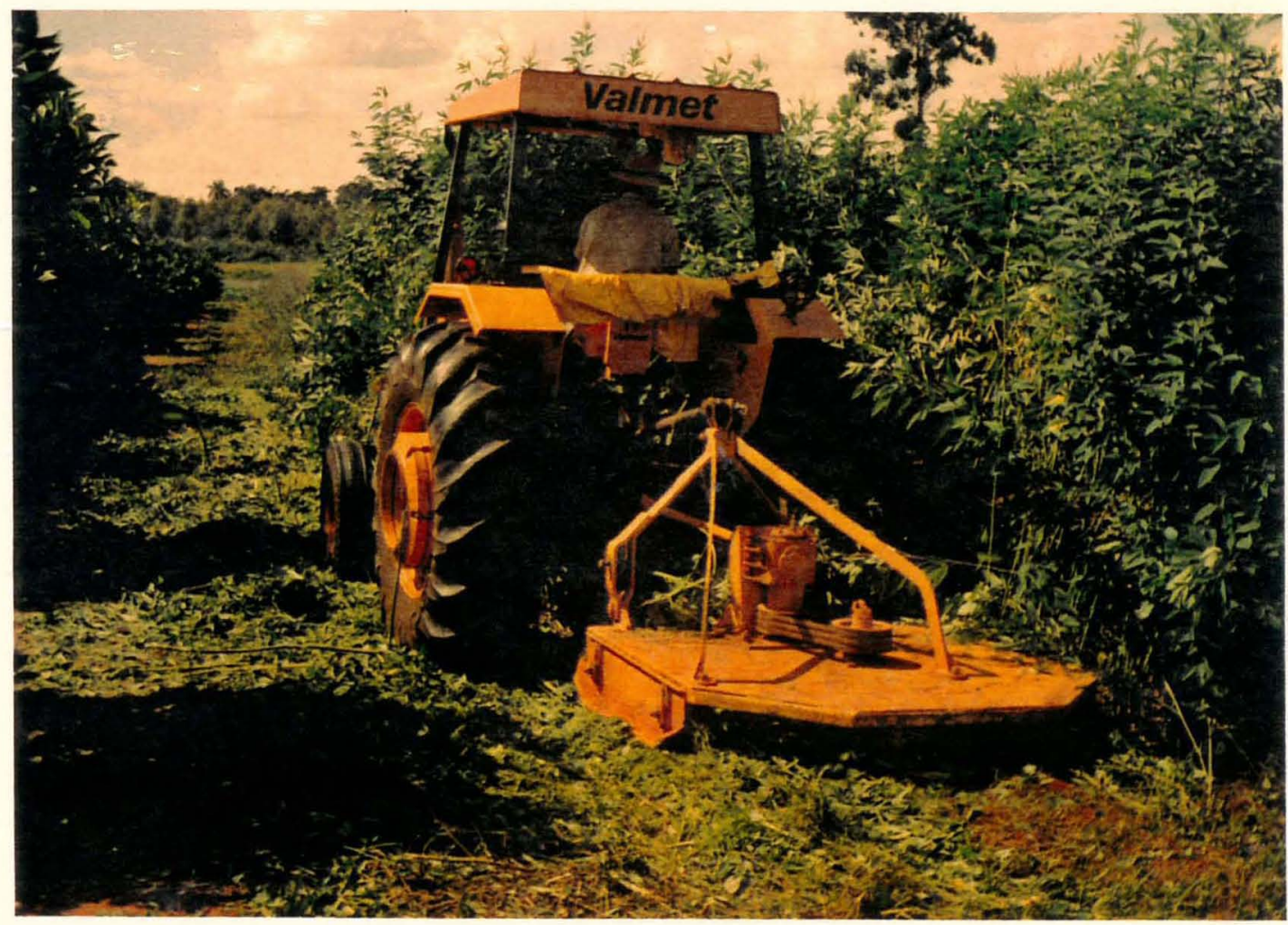

FOTO 10. Aspectos do corte com roçadeira de adubo verde de porte herbáceo (guandú) 


\subsection{Análise química da parte aérea das leguminosas}

Na Tabela 21, estão apresentados os teores de nutrientes na parte aérea das leguminosas cultivadas intercalar a cultura de citros, nos quatro anos agrícolas e, analisando esses dados observa-se diferenças significativas entre as espécies. As espécies mais lenhosas apresentam de modo geral, menores teores de nutrientes, enquanto que as mais herbáceas, maiores teores, principalmente de $\mathrm{N}, \mathrm{S}$ e $\mathrm{P}$, elementos estes fundamentais na formação de proteínas.

Segundo NEME (1959), é muito desejável que as espécies apresentem um teor acima de $15 \mathrm{~g} / \mathrm{kg}$ de $\mathrm{N}$ na parte aérea, pois quando o material orgânico é incorporado ao solo e apresenta menores teores de $\mathrm{N}$, todo o amônio liberado é utilizado pelos microorganismos que atuam no processo de decomposição dos resíduos orgânicos. As espécies de hábito rasteiro, apresentam uma constituição mais tenra da parte aérea e também maiores teores de nitrogênio e enxofre e segundo POLLI \& CHADA (1989), há uma certa relação entre plantas tenras e maior teor de $\mathrm{N}$ na parte aérea. Para IGUE (1984), cerca de $2 / 3$ do $\mathrm{N}$ total das leguminosas é de origem atmosférica $\left(\mathrm{N}_{2}\right)$ e o restante absorvido, numa porcentagem total de $\mathrm{N}$ que varia de 15 a $30 \mathrm{~g} / \mathrm{kg}$ no resíduo orgânico. As leguminosas podem fixar de 20 a $30 \mathrm{~g} / \mathrm{kg}$ de $\mathrm{N}$ na matéria seca, sendo que estas quantidades de $\mathrm{N}_{2}$ fixado pelas diferentes leguminosas, variam de acordo com as espécies, fase da planta avaliada e fatores adversos (WHITE et al., 1955)

Neste estudo, nota-se que o feijão de porco foi a espécie que mais se destacou nos teores de nitrogênio, apresentando $28 \mathrm{~g} / \mathrm{kg}$ deste macronutriente e a Crotalaria juncea os menores teores $14 \mathrm{~g} / \mathrm{kg}$ de $\mathrm{N}$, diferindo dos demais tratamentos pelo teste de Tukey ao nivel de $5 \%$ de probabilidade. Observa-se que ocorre um acrescimo nos teores de $\mathrm{N}$ nos plantios posteriores ao primeiro.

Para $\mathrm{P}$, o labe labe se destacou pela maior produção desse nutriente 2,6 $\mathrm{g} / \mathrm{kg}$, concordando com GALLO et al. (1983), que encontrou os maiores teores de P para esta espécie quando comparado com outras leguminosas. Novamente a Crotalaria juncea apresenta o menor teor de $\mathrm{P}(1,3 \mathrm{~g} / \mathrm{kg})$.

Os teores de $\mathrm{K}$ e Ca mostraram, em média, um decréscimo do primeiro para o quarto ano de cultivo. O feijão de porco, Crotalaria spectabilis e o labe labe se 
destacaram com teores significativamente maiores de $\mathrm{K}$ e $\mathrm{Ca}$. O feijão de porco incorporou em seu material vegetal a média de $18 \mathrm{~g} / \mathrm{kg}$ de $\mathrm{Ca}$, mostrando sua eficiência em absorver este macronutriente do solo. A Crotalaria juncea e o guandú, duas espécies lenhosas apresentaram em média os menores teores de Ca quando comparados com as demais espécies cultivadas.

O labe labe e o feijão de porco, quanto a $\mathrm{Mg}$, apresentam em média os maiores teores (5 e $6 \mathrm{~g} / \mathrm{kg}$ respectivamente), enquanto o guandú o menor $(3 \mathrm{~g} / \mathrm{kg})$.

Os teores de $\mathrm{S}$ decrescem com os anos de condução, sendo que o labe labe e a mucuna anã apresentaram os maiores teores $(2,2$ e $2,0 \mathrm{~g} / \mathrm{kg}$, respectivamente).

Quanto aos micronutrientes $\mathrm{B}, \mathrm{Cu}, \mathrm{Fe}, \mathrm{Mn}$ e $\mathrm{Zn}$, observa-se uma grande variação dos teores entre as espécies e tendência a acréscimo dos teores do primeiro para o quatro ano avaliado. A mucuna anã se destaca pois apresenta entre os tratamentos os maiores teores de $\mathrm{B}, \mathrm{Cu}, \mathrm{Mn}$ e $\mathrm{Zn}$ em relação as demais espécies. Para Fe, a Crotalaria spectabilis apresenta os menores teores $228 \mathrm{mg} / \mathrm{kg}$.

$\mathrm{O}$ micronutriente $\mathrm{Zn}$, não mostrou grandes alterações nos teores entre anos, apresentando entre tratamentos a seguinte ordem decrescente $(\mathrm{mg} / \mathrm{kg})$ : labe labe $>$ mucuna anã $>$ mucuna preta $>$ Crotalaria spectabilis $>$ feijão de porco $>$ Crotalaria juncea $=$ guandú.

Segundo CASTRO (1956), nos primeiros meses do período vegetativo ocorre a mais alta porcentagem de $\mathrm{N}$ nos tecidos das leguminosas, mas a maior quantidade se encontra na floração, sendo o momento mais oportuno para o enterrio, pois as folhas e os talos tenros que constituem as partes mais fáceis para decomposição são atacadas imediatamente pelos microorganismos e começam a formar amônio e nitratos utilizáveis pelas plantas. A velocidade e grau de decomposição depende de condições de umidade, temperatura, aeração, textura do solo e conteúdo de minerais, segundo o mesmo autor.

No ano agrícola 90/91, os adubos verdes foram incorporados aos 148 dias após semeadura ao contrário dos demais anos (110 dias), resultando com esse procedimento na diminuição dos teores médios por ano de $\mathrm{N}, \mathrm{P}, \mathrm{Ca}, \mathrm{Mg}, \mathrm{B}$ e $\mathrm{Zn}$. 


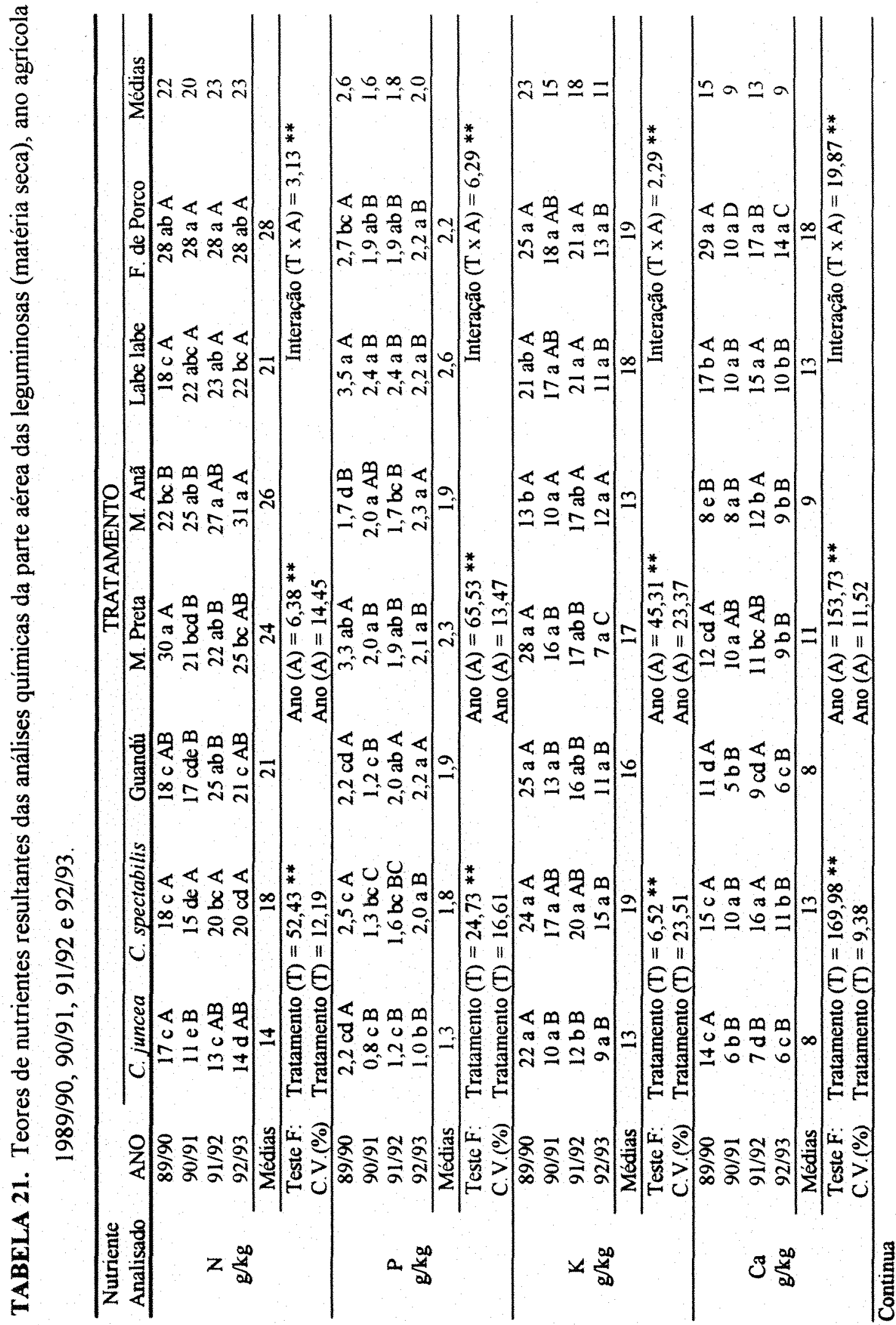




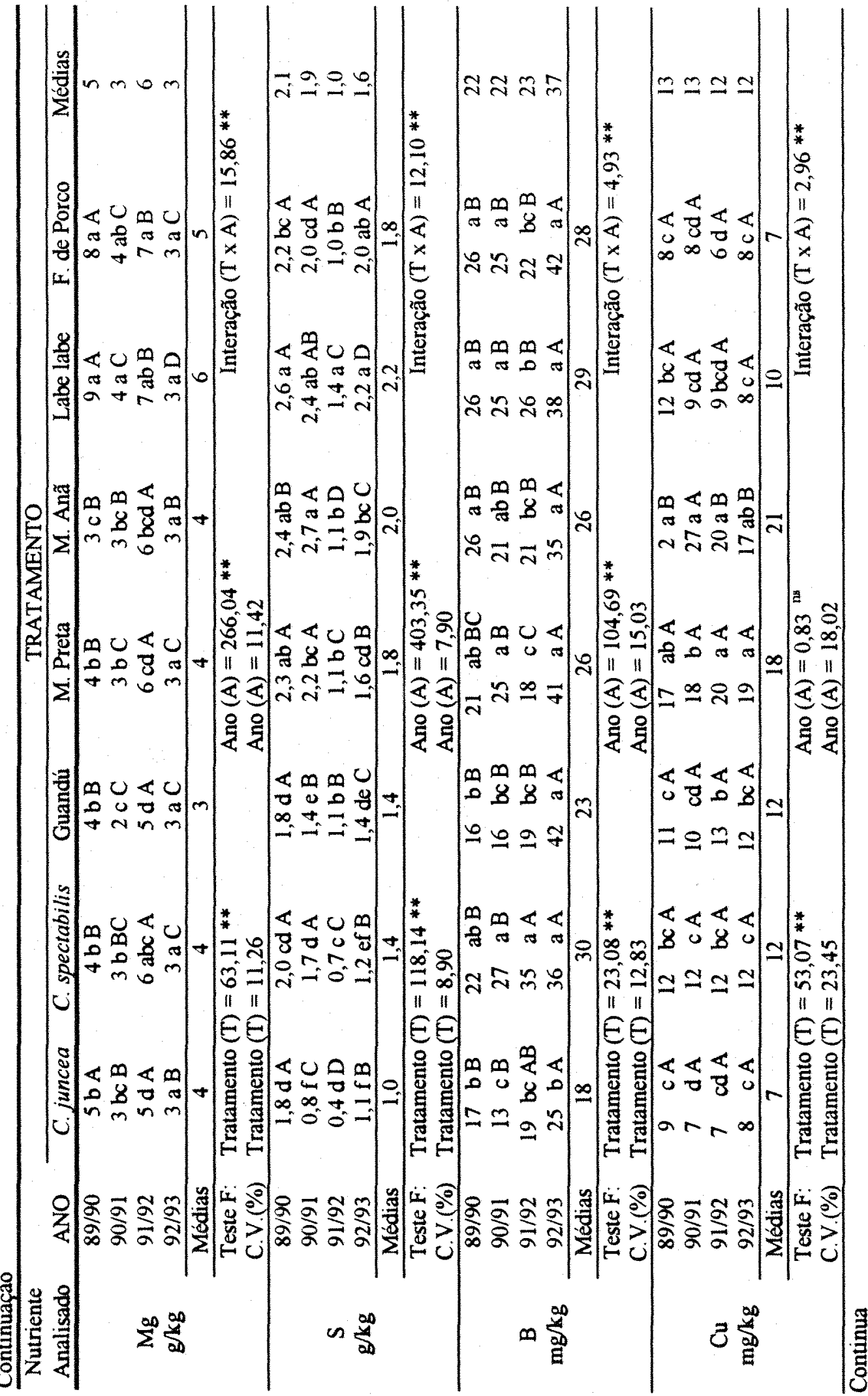




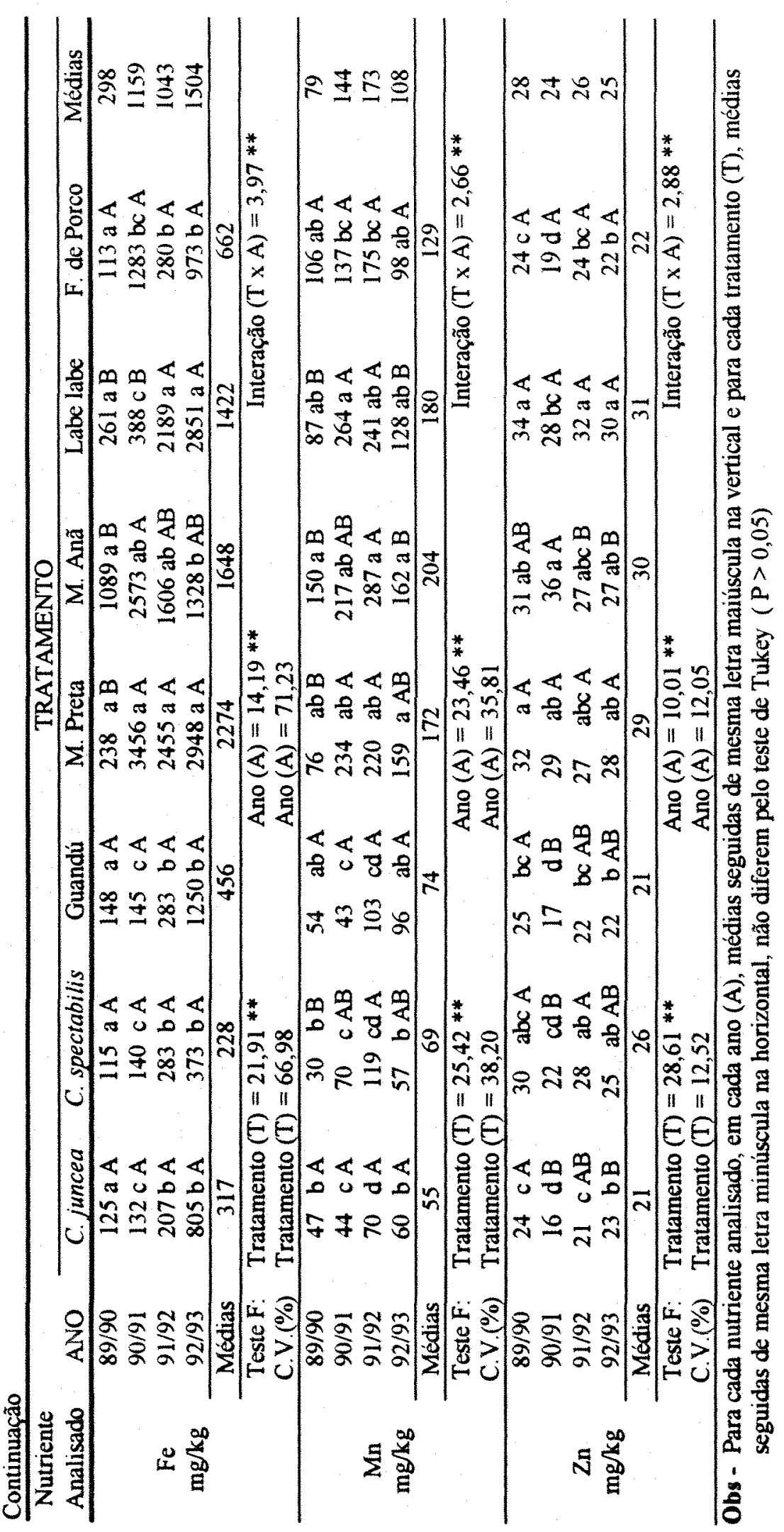


4.10. Nutrientes presentes na matéria seca da parte aérea das leguminosas e incorporados ao solo

A quantidade de macro e micronutrientes $\left(\mathrm{N}, \mathrm{P}_{2} \mathrm{O}_{5}, \mathrm{~K}_{2} \mathrm{O}, \mathrm{Ca}, \mathrm{Mg}, \mathrm{S}, \mathrm{B}\right.$, $\mathrm{Cu}, \mathrm{Fe}, \mathrm{Mn}$ e $\mathrm{Zn}$ ), incorporados ao solo pelas leguminosas, sendo estes valores a média de quatro anos do plantio dos adubos verdes intercalar ao citros, estão apresentados na Tabela 22.

É de se destacar as altas quantidades de $\mathrm{N}$ e $\mathrm{K}$ incorporados ao solo, principalmente, pela Crotalaria juncea, guandú e feijão de porco, indicando a grande contribuição da adubação verde, como fonte de nutrientes, conforme já observado por MELLO (1978).

Os valores apresentados estão $\mathrm{em} \mathrm{kg} / \mathrm{ha}$, considerando se fosse plantado o adubo verde em área total (100\%), porém o plantio se restringiu apenas à área intercalar do citros, ou seja, numa faixa de $3,5 \mathrm{~m}$, que corresponde a $50 \%$ da entrelinha dos citros, que no caso possui $7,0 \mathrm{~m}$ entre as linhas de citros.

Como foi apresentado na Tabela 21, a Crotalaria juncea foi a espécie que apresentou os menores teores de nutrientes na fitomassa verde, que por sua vez é o de maior volume quando comparado com as demais espécies utilizadas. Isso é devido ao estadio em que foi incorporado, resultando na incorporação ao solo de $183,4 \mathrm{~kg} / \mathrm{ha}$ de $\mathrm{N}$ (considerando o plantio na área intercalar ao citros, equivalente a $91,7 \mathrm{~kg} / \mathrm{ha}$ de $\mathrm{N}$ ), que corresponderia a aplicação de $408 \mathrm{~kg}$ de uréia/ha (considerando o plantio na área intercalar ao citros, equivalente a $204 \mathrm{~kg}$ de uréia/ha).

A Crotalaria spectabilis e a mucuna anã, foram as especies que incorporaram as menores quantidades de nutrientes ao solo, provavelmente devido a Crotalaria spectabilis, ter produzido a menor quantidade de material vegetal e a mucuna anã à suscetibilidade ao fungo da cercosporiose que prejudicou o desenvolvimento da espécie.

É de se destacar a quantia de $108,9 \mathrm{~kg} /$ ha de cálcio presente no material verde do feijão de porco. 
Estas quantidades de nutrientes apresentadas na Tabela 22 e ilustradas nas Figuras 2, 3, 4 e 5, relacionam-se somente à parte aérea das leguminosas. Estas quantias seriam consideravelmente aumentadas se fossem somadas a elas o sistema radicular das espécies. É oportuno lembrar que parte do $\mathrm{N}$ presente no material vegetal das leguminosas foi obtido pela fixação simbiótica de $\mathrm{N}_{2}$ atmosférico, que corresponde segundo IGUE (1984), a $2 / 3$ do $\mathrm{N}$ total das leguminosas, o restante é absorvido do solo, numa quantidade total de $\mathrm{N}$ que varia de 15 a $30 \mathrm{~g} / \mathrm{kg}$ do resíduo orgânico. Os demais macro e micronutrientes são provenientes da reciclagem de nutrientes efetuado por estas espécies, que absorvem o nutriente lixiviado no perfil do solo, das camadas subsuperficiais trazendo-os à superficie novamente e incorporando-os ao solo onde poderão estar disponíveis às culturas economicas. Este processo de incoporação de nutrientes lixiviados nas camadas superficiais cabe muito bem a cultura de citros, que apresenta, segundo RODRIGUES (1980), concentração das raízes nos 40 a $60 \mathrm{~cm}$ de profundidade. MONTENEGRO (1960), estudando o sistema radicular dos citros com mais de dez anos encontrou acima de $90 \%$ das raízes nos primeiros $90 \mathrm{~cm}$ do solo.

TABELA 22. Quantidade média de nutrientes incorporados ao solo pelas leguminosas após quatro anos de semeadura intercalar ao citros.

\begin{tabular}{|c|c|c|c|c|c|c|c|c|c|c|c|}
\hline \multirow[t]{2}{*}{ Tratamentos } & \multicolumn{6}{|c|}{ Macronutrientes $\mathrm{kg} / \mathrm{ha}$} & \multicolumn{5}{|c|}{ Micronutrientes $\mathrm{g} / \mathrm{ha}$} \\
\hline & $\bar{N}$ & $\mathrm{P}_{2} \mathrm{O}_{5}$ & $\mathrm{~K}_{2} \mathrm{O}$ & $\mathrm{Ca}$ & $\mathbf{M g}$ & $S$ & $\bar{B}$ & $\mathrm{Cu}$ & $\mathrm{Fe}$ & $\mathbf{M n}$ & $\mathrm{Zn}$ \\
\hline C. juncea & 183,4 & 39,2 & 204,4 & 104,8 & 52,4 & 13,1 & 236 & 92 & 4.153 & 721 & 275 \\
\hline C. spectabilis & 44,3 & 10,2 & 56,1 & 38,4 & 9,8 & 3,4 & 74 & 30 & 561 & 170 & 64 \\
\hline Guandú & 143,6 & 29,9 & 131,3 & 54,7 & 20,5 & 9,6 & 157 & 82 & 3.119 & 506 & 144 \\
\hline Mucuna preta & 85,6 & 18,8 & 72,6 & 39,2 & 14,2 & 6,4 & 93 & 64 & 8.095 & 612 & 103 \\
\hline Mucuna anã & 91,0 & 15,3 & 54,6 & 31,5 & 14,0 & 7,0 & 91 & 74 & 5.768 & 714 & 105 \\
\hline Labe labe & 67,4 & 19,2 & 69,3 & 41,7 & 19,3 & 7,1 & 93 & 32 & 4.565 & 578 & 100 \\
\hline Feijão de porco & 169,4 & 30,6 & 137,9 & 108,9 & 30,3 & 10,9 & 169 & 42 & 4.005 & 780 & 133 \\
\hline
\end{tabular}

Obs: Quantidade de nutrientes considerando plantio em área total, para área de citros utilizada, considerar $50 \%$ dos valores. 


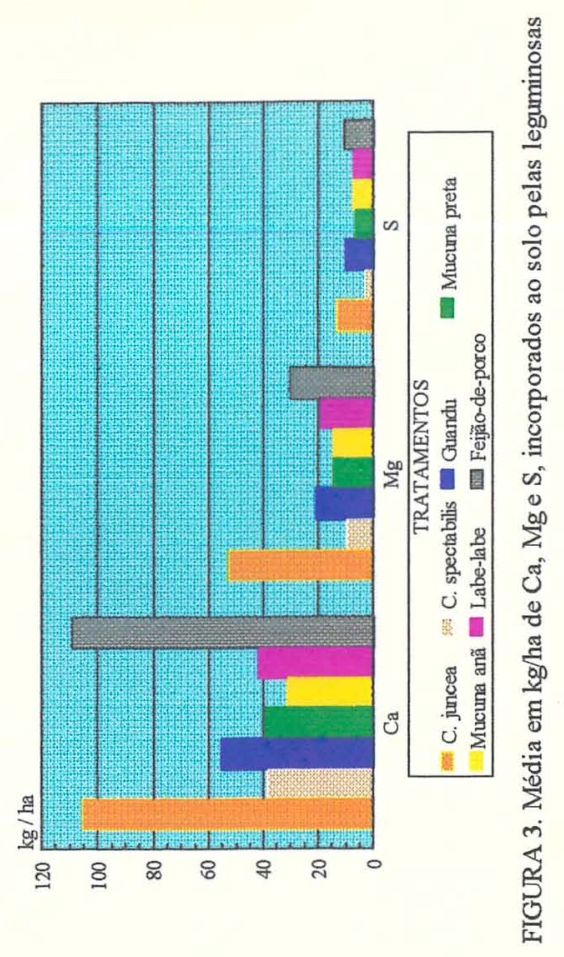

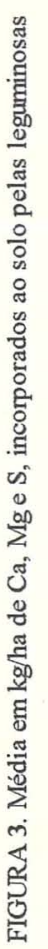
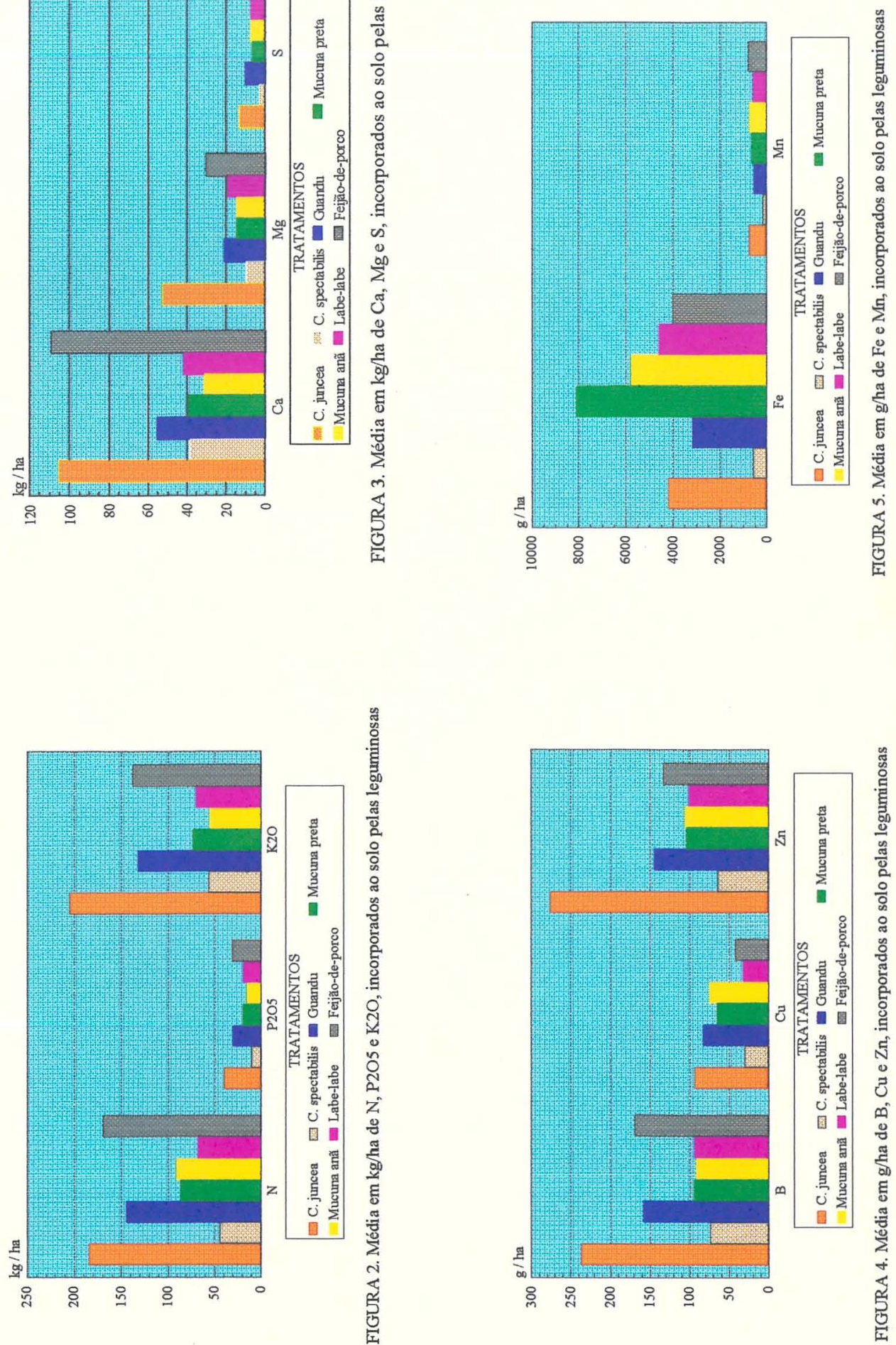
Resumindo os dados apresentados na Tabela 22, observou-se mais uma vez a superioridade da Crotalaria juncea em reciclar ao solo quantidades significativas de nutrientes, principalmente $\mathrm{N}$, seguido pelo guandú e feijão de porco.

\subsection{Produção de frutos citricos}

A produção média das plantas da área experimental (Tabela 23 e Figura 6), encontraram-se abaixo do valor considerado ideal economicamente, ou seja, em média a laranjeira Pera deve produzir $250 \mathrm{~kg} /$ planta, apartir do quinto ano, segundo FIGUEIREDO, (1991). No ano agrícola de $1992 / 93$ as plantas cítricas utlilizadas já estavam com mais de 5 anos e produtividade máxima de $80,56 \mathrm{~kg} /$ planta, na parcela onde se utilizou o guandú, porém, acredita-se que a baixa produtividade observada, não se deva aos tratamentos utilizados, mas sim às plantas que apresentavam deficiências nutricionais, lesões de pragas e doenças antes a implantação do experimento, porém gradativamente após a implantação do experimento as plantas melhoraram bastante seu aspecto e desenvolvimento.

Como era de se esperar, observou-se aumento médio de produtividade com o passar dos anos e desenvolvimento das plantas cítricas e não foi observado diferenças significativas entre tratamentos. Porém a diferença não significativa entre tratamentos, mostra que esse resultado quando obtido em áreas maiores, resultaria em um rendimento favorável ao citricultor, sem contar que nas parcelas com adubos verdes não se teve despesas com adubos nitrogenados, portanto, pode-se inferir que o uso de adubação verde pode ter sido suficiente para nutrir as plantas cítricas deste macronutriente, mantendo uma produtividade superior em determinadas parcelas com adubos verdes, comprovando os resultados de outros ítens avaliados deste mesmo trabalho, a este respeito. Quando o $\mathrm{N}$ foi utilizado em dose dupla (tratamento 2NPK) do recomendado pelo GRUPO PAULISTA (1988), a produção foi superior ao tratamento NPK (dose recomendada), porém não significativo. 


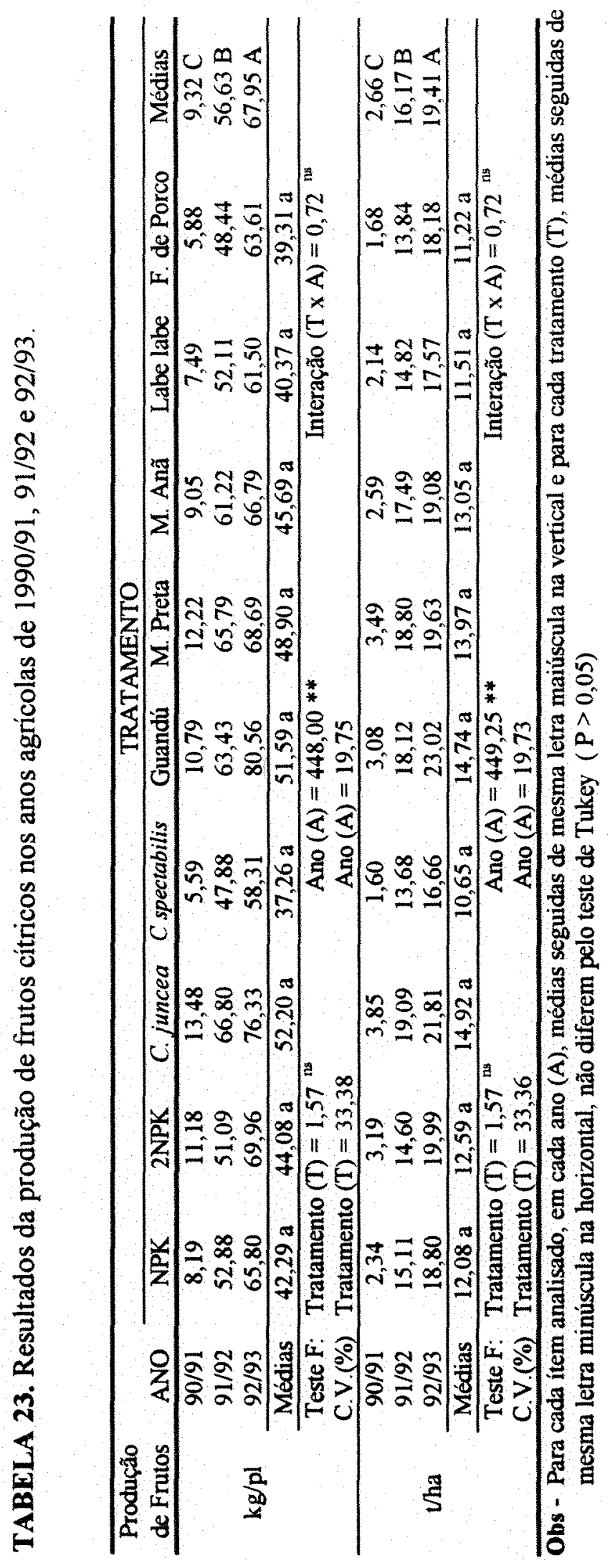


O tratamento com Crotalaria juncea apesar de não significativo, produziu cerca de 3 t/ha a mais de frutos, similar ao tratamento com guandú. Em ordem decrescente de produção teve-se os seguintes tratamentos: Crotalaria juncea $>$ guandú $>$ mucuna preta $>$ mucuna anã $>2 \mathrm{NPK}>\mathrm{NPK}>$ labe labe $>$ feijão de porco $>C$. spectabilis.

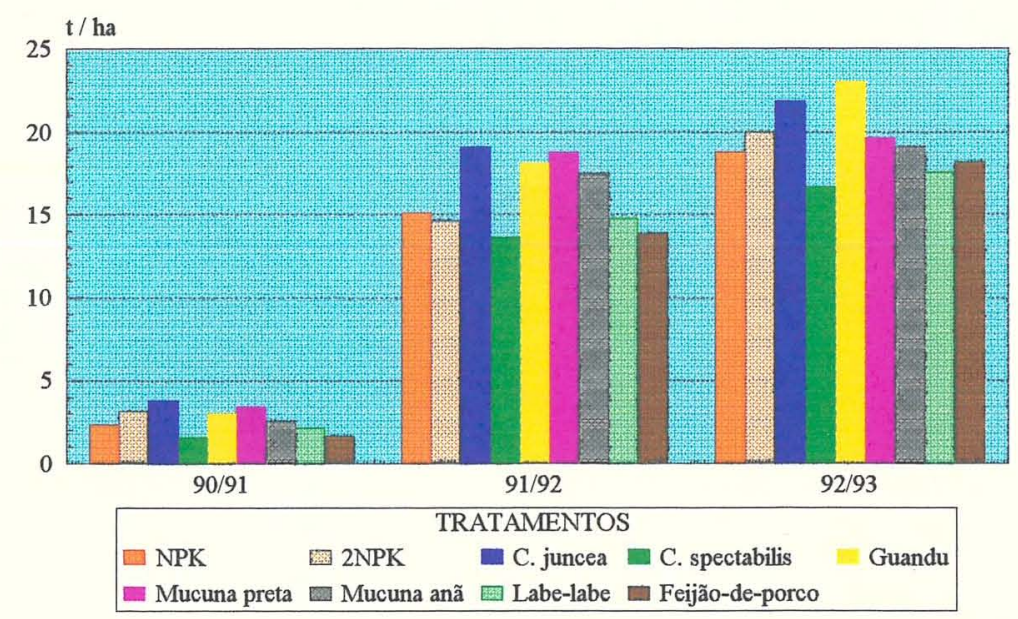

FIGURA 6. Produção de frutos cítricos, tha

\subsection{Análise tecnológica de frutos cítricos}

Na Tabela 24, são apresentados os resultados da análise tecnológica dos frutos da laranjeira Pera utilizada no experimento. Verifica-se que a mucuna preta apresentou os maiores valores para o peso e tamanho dos frutos frescos, quando comparados com o tratamento NPK, diferindo estatisticamente. O peso médio dos frutos da laranjeira Pera segundo FIGUEIREDO (1991), é de $145 \mathrm{~g}$ e na área experimental, obtive-se peso médio de $180 \mathrm{~g}$. Possivelmente, este maior peso foi devido à menor produtividade da planta.

Não observou-se diferenças significativas entre tratamentos para o ${ }^{\circ}$ brix, que ficou em média 1,0 ponto inferior ao citado por FIGUEIREDO (1991), que obteve $11,8^{\circ}$ brix para laranja Pera e DI GIORGI et al (1990), que obteve a média de 11,6 ${ }^{\circ}$ brix nas safras 1987, 1988 e 1989. Poder-se-ia chegar a valores próximos aos obtidos pelos autores acima, se fosse retardada a colheita. 
Os valores médios entre tratamentos obtidos para a acidez titulável $(0,82)$, ratio $(13,4)$ e porcentagem de suco $(51)$, ficaram muito próximos aos citados por FIGUEIREDO (1991), que obteve os valores de 0,95; 12,5 e 52 respectivamente, para frutos de laranja Pera, por outro lado, DI GIORGI et al. (1990), obteve em 3 safras a média de $57,5 \%$ de suco.

A Figura 7, ilustra a relação entre a produção de frutos em kg/pl (Tabela 23) e o volume da copa das plantas cítricas em $\mathrm{m}^{3}$ (Tabela 13), no ano agrícola de 1992/93, oque é denominado IE (índice de eficiência foliar ou produção por unidade de volume de copa). De acordo com a Figura 7, verificou-se que o feijão de porco apresentou maiores índices de eficiência, ou seja, maior produção de frutos por unidade de volume de copa.

Ao analisar-mos o IT (índice tecnológico $=$ sólidos solúveis $\mathrm{kg} / \mathrm{cx}$ ), verificamos que houve um aumento significativo do ano agrícola de 1991/92 para 92/93, e não houve diferença significativa entre os tratamentos, porém os valores médios dos tratamentos $(2,23 \mathrm{~kg} / \mathrm{cx})$, encontram-se abaixo dos valores médios de três safras encontrados por DI GIORGI, et al. (1990) para a laranja Pera $(2,72 \mathrm{~kg} / \mathrm{cx})$, com rátio de 12 a 14.

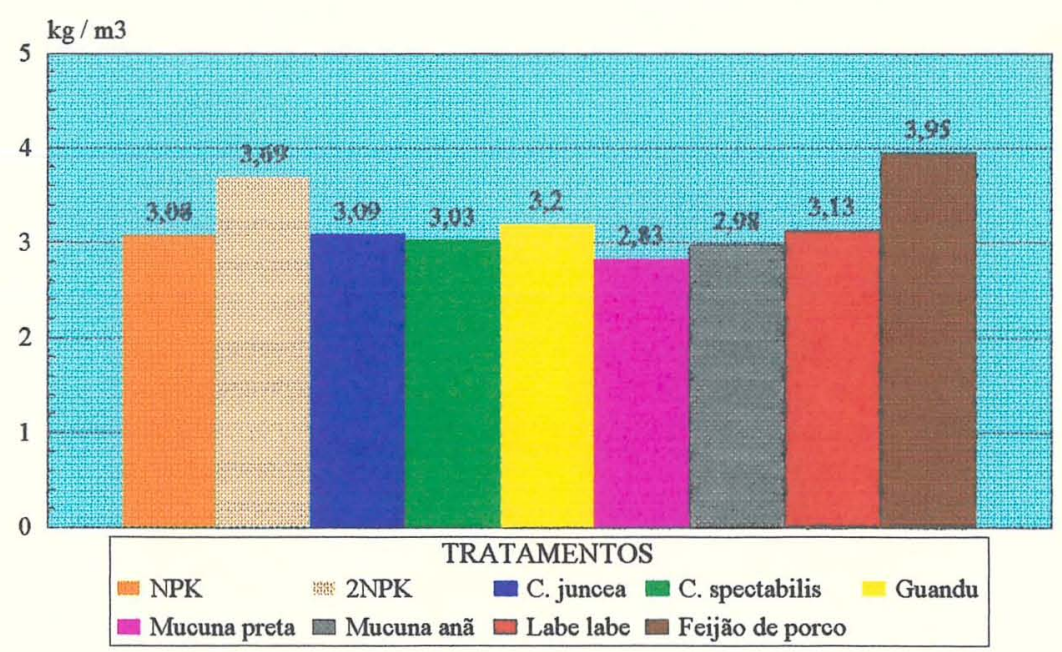

FIGURA 7. Índice de eficiência produtiva (kg/m3), no ano agrícola 1992/93 


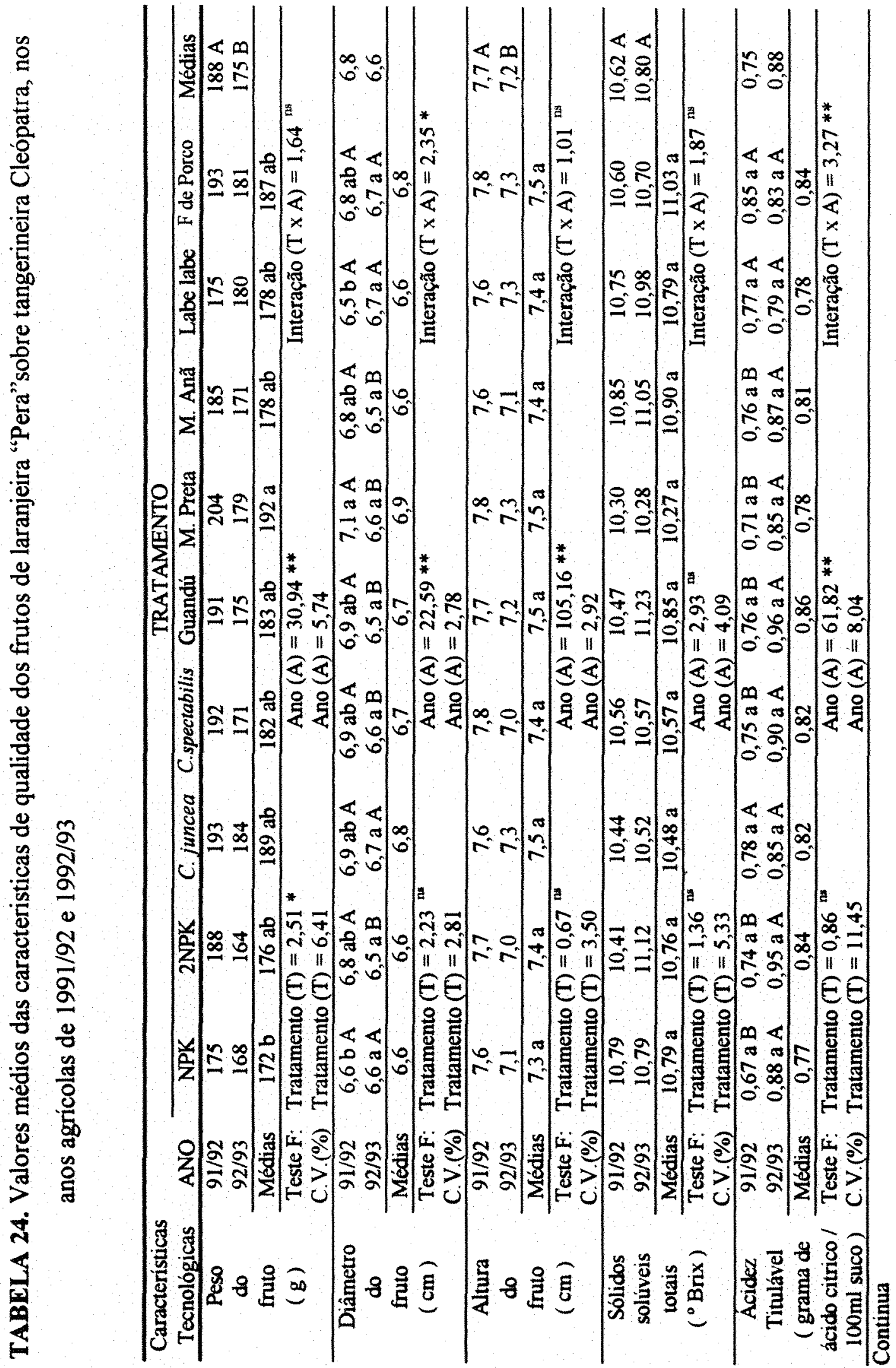




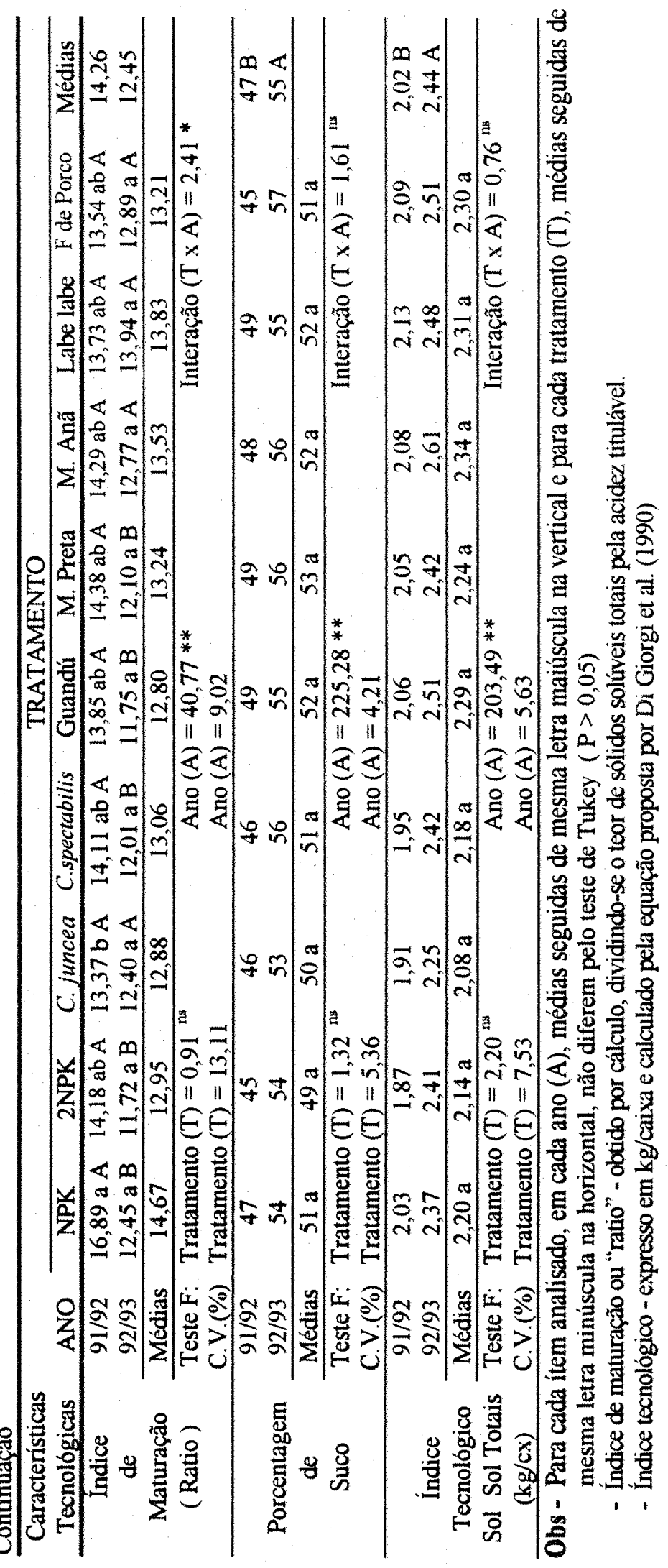




\section{CONSIDERAÇÕES FINAIS}

Através dos resultados obtidos no projeto de pesquisa, obserou-se que:

- a Crotalaria juncea, mucuna preta e guandú, mostraram-se eficientes na cobertura do solo e no controle de plantas daninhas;

- o desenvolvimento das plantas cítricas avaliados através do volume de copa e diâmetro de tronco, bem como, a produção de frutos cítricos, não foram afetados significativamente pela utilização dos adubos verdes, embora os tratamentos com guandú e Crotalaria juncea, tenham apresentados melhores produções de frutos cítricos no ultimo ano;

- os tratamentos não influenciaram significativamente em características químicas do solo e nos teores de nutrientes das folhas de citros, situando-se os mesmos na faixa de teores adequados;

- a análise química do solo dos tratamentos que receberam a aplicação de $\mathrm{N}$ mineral, resultou em menores valores de $\mathrm{pH}$;

- quanto a produção de matéria seca da parte aérea, dos adubos verdes, observou-se a seguinte ordem decrescente: Crotalaria juncea $>$ guandú $=$ feijão de porco $>>$ mucuna preta $>$ mucuna anã $>$ labe labe $>$ Crotalaria spectabilis;

- a espécies estudadas mostraram ser grandes incorporadoras de $\mathrm{N}$ e recicladoras de nutrientes ao solo; 
- não é aconselhável a utilização em cultivo intercalar em citros na região de BebedouroSP, da Crotalaria spectabilis, devido a germinação lenta e consequentemente competição com plantas daninhas; da mucuna anã, pela suscetibilidade a cercosporiose e da mucuna preta pela sua excessiva agressividade (hábito trepador);

- de modo geral a Crotalaria juncea, seguida pelo guandú e feijão de porco, foram as espécies mais adequadas à prática de adubação verde em citros. 


\section{CONCLUSÕES}

1. O emprego de adubos verdes intercalares, contribue para a redução da aplicação de nitrogênio mineral em pomares de citros, em formação;

2. A Crotalaria juncea, é a espécie de adubo verde mais indicada para pomares de citros em formação;

3. A adubação verde reduz a incidência de plantas daninhas e incrementa a reciclagem de nutrientes na formação de pomares de citros. 


\section{REFERÊNCIAS BIBLIOGRÁFICAS}

ALMEIDA, F.S. A alelopatia e as plantas. Londrina, IAPAR, 1988.60p. (IAPAR. Circular, 53).

ANDRIOLI, I; CENTURION, J.F.; MARQUES JUNIOR, J. Levantamento detalhado dos solos da Estação Experimental de Citricultura de Bebedouro. Jaboticabal, UNESP/FCAV, 1994. 19p. (Relatório).

ASLANDER, A. \& NEEME, A. Influência que ejercem los materiales orgânicos sobre la fijación del potasio en el suelo. Revista de la Potasa, Berna, 2(16):1-2, ago, 1965. (Separata de Transaction of the Royal Institute of Technology, Stockholm, 236.)

AZEREDO, F.D. \& MANHÃES, M.S. Adubação orgânica. In: ORLANDO FILHO, J. Nutrição e adubação da cana-de-açucar no Brasil Piracicaba, Planalsucar, 1983. p. $211-25$.

BANZATTO, D.A. \& KRONKA, S.N. Experimentação agrícola. Jaboticabal, FUNEP, 1989. 247p.

BRAGA, N.R. Adubação verde para citros. Laranja, Cordeirópolis, $\underline{7}(1)$ :299-307, 1986.

BULISANI, E.A. Aproveitamento do labe-labe. O Estado de São Paulo, 1974. Suplemento Agrícola, São Paulo, 20:5. 
CAETANO, A.A. Tratos culturais. In: RODRIGUEZ, O \& VIÉGAS, F. Citricultura brasileira. Campinas, Fundação Cargill, 1980. p. 429-44.

CALEGARI, A. Tremoço no sudoeste do Paraná. In: REUNIÃo BRASILEIRA DE TREMOÇO ( Lupinus sp.). Anais. Passo Fundo, EMBRAPA-CNPT, 1986. p.35-7.

CAMARGO, T.L.A. \& HERMANN, J. Contribuição para o dstudo da adubação verde das terras roxas cansadas. Campinas, Instituto Agronômico, 1928. 22p. (IAC. Boletim Técnico, 1).

CASTRO, F.S. Conservación de suelos. Barcelona, Salvat, 1956. 298p.

CINTRA, P.L.D. \& MIELNICZUK, J. Potencial de algumas espécies regetais para a recuperação de solos com propriedades fisicas degradadas. Revista Brasileira de Ciência do Solo. Campinas, 1983. (7):19-201.

CLARKSON, D.T. Adaptações morfológicas e fisiológicas das plantas a ambientes de baixa fertilidade. In: SIMPÓSIO SOBRE RECICLAGEM DE NUTRIENTES E AGRICULTURA DE BAIXOS INSUMOS NOS TÓPICOS. Ilhéus, Reunião Brasileira de Fertilidade do Solo, 16:45-7, 1985.

COSTA, M.B.B. Adubação orgânica: nova síntese e novo caminho para a agricultura. São Paulo, Icone, 1989. 107p. (Coleção Brasil Agrícola)

COSTA, M.B.B; CALEGARI, A.; MONDARD, A; BULISANI, E.A; WILDNER, L.P.; ALCÂNTARA, P.B.; MIYASAKA, S.; AMADO, T.J.C. Adubação verde no sul do Brasil. 2.ed. Rio de Janeiro, AS-PTA, 1993. 346p.

CRUZ, A.L. Adubação verde, Rio de Janeiro, SIA, 1985. 42p. (SIA, 813)

DERPSCH, R. Adubação verde, Rio de Janeiro, SIA, 1985. 42p. 
DERPSCHI, R. \& CALEGARI, A. Guia de plantas para adubação verde de inverno. Londrina, IAPAR, 1985. 96p. (IAPAR, 9)

DERPSCHI, R.; SIDIRAS, N.; HEINZMANN, F.X. Manejo do solo com coberturas verdes de inverno. Pesquisa Agropecuária Brasileira. 20(7):761-73, 1985.

DI GIORGE, F.; IDE, B.Y.; MARCHI, R.J.; TRIBONI, H.R.; WAGNER, R.L. Contribuição ao estudo do comportamento de algumas variedades de citros e suas aplicações agroindustriais. Laranja, Cordeirópolis, 11(2)565-612, 1990.

FAO. Inoculantes para leguminosas $Y$ su uso. Roma, 1985. $61 \mathrm{p}$.

FIGUEIREDO, J.O. Variedades copa de valor comercial. In: Citricultura Brasileira. Fundação Cargill, Campinas, 2(1)228-64, 1991.

FRANCO, A.A. \& SOUTO, S.M. Contribuição da fixação biológica de $\mathrm{N}_{2}$ na adubação verde. In: Adubação verde no Brasil. Fundação Cargill. Campinas, 1984. p. 199-15.

FREITAS, L.M.N. Adubação de leguminosas tropicais. In: REUNIÃO LATINO AMERICANA DO RHIZOBIUM. 1971. ㅁ:193-209.

GALETI, P.A \& TRANI, P.E. Adubação verde, uma boa opção. Casa da Agricultura, 9:35, 1987.

GALLO, J.R. \& RODRIGUES, O. Efeitos de algumas práticas de cultivo do solo na nutrição mineral dos citros. Bragantia, 19:345-60, 1960.

GALLO, P.B.; SAWAZAKI, E.; WIKOCE, R; MASCARENHAS, H.A.A. A produção de milho afetado pelo nitrogênio e cultivos anteriores com soja. Revista Brasileira de Ciência do Solo. 7:149-52, 1983.

GLORIA, N.A da; MATTIAZO, M.E.; PEREIRA, V.; PARO, J.M. Avaliação da produção de adubos verdes. Saccharum, São Paulo, 3 (8):31-5, 1980. 
GRANER, E.A. \& GODOY JUNIOR, C. Culturas da fazenda brasileira. 4.ed. São Paulo, Melhoramentos, 1967. p.19-461.

GRUPO PAULISTA DE ADUBAÇÃO E CALAGEM PARA CITRUS. Recomendações de adubação e calagem para citrus no Estado de São Paulo. Laranja, Cordeirópolis SP, 9(3), 1988. 15p.

GRUPO PAULISTA DE ADUBAÇÃO E CALAGEM PARA CITRUS. Recomendações de adubação e calagem para citrus no Estado de São Paulo. Laranja, Cordeirópolis SP, 1994. 27p.

GUSTAFSON, A.F. Soils and soil management. New York, Mac-Graw-Hill, 1941. $424 \mathrm{p}$.

HEINZMANN, F.X. Mineralização dos resíduos das culturas de inverno e assimilação de nitrogênio pelas culturas de verão sob plantio direto. In: CONGRESSO BRASILEIRO DE CIÊNCIA DO SOLO. Curitiba PR, 1983. p.59.

INSTITUTO AGRONÔMICO DO PARANA. Adubação orgânica. In: Relatório técnico anual-1982. Londrina, 1984. 326p.

INSTITUTO AGRONÔMICO DO PARANA. Guia de adubação verde de inverno. Londrina, 1985. 96p. (IAPAR, Documentos, 9).

IGUE, K. Dinâmica da matéria orgânica e seus efeitos nas propriedades do solo. In: FUNDAÇÃo CARGILL. Adubação verde no Brasil. Campinas, Fundação Cargill, 1984. p.232-67.

JONES, W.W. \& EMBLETON, T.W. Soils, soil management and cover crops. In: REUTHER, W., BATCHELOR, L.D., WEBBER, H.J. The citrus industry. Berkeley, University of California, Division of Agricultural Sciences, 1973 v. 3, p. 98-121. 
KIEHL, E.J. Consorciação de leguminosas II - Novas disposição das linhas de plantas suportes. In: CONGRESSO BRASILEIRO DE CIÊNCIA DO SOLO, 7. Piracicaba, 1959.

KLUTHCOUSKI, J. Leucena: alternativa para pequena e média agricultura. Goiânia, EMBRAPA-CNPAF, 1980. 23p. (Circular Técnica, 6).

LYNCH, J.M. Biotecnologia do solo. São Paulo, Ed. Manole, 1986. 209p.

LORENZI, H. Manual de identificação e controle de plantas daninhas. Marprint, Nova Odessa, 1984. 220p.

MAGALHÃES, A.F. de J. Adubação verde na cultura dos citros. In: CONGRESSO BRASILEIRO DE FRUTICULTURA, 1994. Salvador, 13(2):505-6.

MALAVOLTA, E. Manual de química agrícola; nutrição de plantas e fertilidade do solo. São Paulo, Editora Agronômica Ceres, 1976. 528p.

MALAVOLTA, E. Fixação biológica do nitrogênio. O Estado de São Paulo, São Paulo, 1977. Suplemento Cultura, $\underline{45}$ : 13-4.

MALAVOLTA, E. Potassium status of tropical and subtropical region soils. In: MUNSON, R.D., Potassium in agriculture. Madison: American Society of Agronomy, Crop Science Society of America, Soil Science Society of America, 1985. p. 163-200.

MALAVOLTA, E.; VITTI, G.C.; OLIVEIRA, S.A. Avaliação do estado nutricional das plantas; princípios e aplicações. Piracicaba SP, Associação Brasileira para Pesquisa de Potássa e do Fosfato, 1989. 201p.

MARTIN, J.P. \& WAKSMAN, S.A. Influence of microorganisms on soil aggregation and erosion II. Soil Science, Baltimore, 52:381-94, 1941. 
MARUM, F.; ANDROCIOLLI, A.; VIEIRA, M.J. Manejo fitoedáfico para recuperação de cafeeiros depauperados cultivados em solo arenoso. In: CONGRESSO BRASILEIRO DE CONSERVAÇÃO DO SOLO E ENCONTRO NACIONAL DE PESQUISA SOBRE CONSERVAÇÃO DO SOLO. 6, Campo Grande, 1986. Campinas, Fundação Cargill, 1986. 26p.

MELO, W.J. \& CARDOSO, E.J.B.N. Produção de material seca e marcha de acúmulo de nitrogênio por labe-lbe cultivado após a cultura de milho. In: CONGRESSO BRASILEIRO DO SOLO, Campinas, (15):221-4, 1975.

MELLO, F.A.F. Fixação de nitrogênio por algumas leguminosas. Revista de Agricultura, Piracicaba, (53):59, 1978.

MELLO, F.A.F. Fertilidade do solo. São Paulo, Nobel, 3.ed. 1988.

MONTENEGRO, H.W.S. Contribuição ao estudo do sistema radicular das plantas cítricas. Piracicaba, 1960. $189 \mathrm{p}$.

MIYASAKA, S.; FREIRE, E.S.; MASCARENHAS, H.A.A. Efeito da matéria orgânica sobre a produção do feijoeiro. In: CONGRESSO BRASILEIRO DE CIÊNCIA DO SOLO, 10, Piracicaba, 1965.

MIYASAKA, S.; GALLO, J.R.; SILVA, J.G. Histórico de estudos de adubação verde, leguminosas viáveis e suas características. In: ADUBAÇÃO VERDE NO BRASIL, Campinas, Fundação Cargill, 1984. p.64-123.

MTYASAKA, S.; CAMARGO, O.A.; CAVALERI, P.A. Adubação orgânica, adubação verde e rotação de culturas no Estado de São Paulo. 2 ed. Campinas, Fundação Cargill, 1984. 138p.

NEME, N.A. Leguminosas para adubos verdes e forragens. Campinas, Instituto Agronômico, 28 p. 1940. (IAC. Boletim 109) 
NEME, N.A. Leguminosas para adubos verdes e forragens. Campinas, Instituto Agronômico, 1959. (IAC. Boletim Técnico).

OLIVEIRA, R.A. Influência do sorgo e do labe-labe, em sucessão ao milho, sobre propriedades químicas de um Latossolo (LEM). Jaboticabal, UNESP/FCAV, 1987. 87p.

PAVAN, M.A.; BINGHAM, F.T.; PRATT, P.F. Chemical and mineralogical characteristics of selected acid soils of the State of Paraná, Brazil. Turrialba, 1985.

POLLI, H. de \& CHADA, S. de S. Adubação verde ou em cobertura na produção de milho em solo de baixo potêncial de produtividade. Revista Brasileira de Ciência do Solo, Campinas, 13:3, 1989.

POMPEU Jr., J. Estudo de comportamento de clones nucelares e velhos de laranjeira Hamlin (Citrus sinensis L. Osbeck) em dois porta-enxertos. Piracicaba, USP/ESALQ, 1972. 77p. (Tese de Doutoramento).

PROEBSTING, E.L. Some effects of long continued cover cropping in a California orchard. Proceeding of the American Society for Horticultural Science, St. Joseph, $\underline{60}: 87-90,1952$.

RAIJ, B. van. A capacidade de troca catiônica nas frações orgânicas e minerais em solo. Bragantia, Campinas, 28(8):85-112, 1969.

RAIJ, B. van \& QUAGGIO, J.A. Métodos de análises de solo para fins de fertilidade. Campinas, Instituto Agronômico, 1983. 31p. (IAC, 81).

REDD, J.B.; HENDRIX Jr. C.M.; HENDRIX, D. L. Qualitycontrol manual for citrus processing plants intercit. Florida, 1986, 250p.

RODRIGUEZ, O. Nutrição e adubação dos citros. In: RODRIGUEZ, O. \& VIÉGAS, F. Citricultura brasileira, Campinas, Fundação Cargill, 1980, 2:387-430. 
SANTOS, M.A. \& RUANO, O. Reação de plantas usadas como adubos verdes a Meloidogyne incognita; Raça 3 e $M$. javanica. Nematologia Brasileira, S.I., (11):184-97, 1987.

RUSSELL, R.S.; IGUE, K; MEHTA, Y.R. The soil-root system in relation to Brazilian agriculture. Londrina, IAPAR, 1981. 372p.

SCARANARI, H.J. \& INFORZATO, R. Sistema radicular das principais leguminosas empregadas como adubo verde em cafezal. Bragantia. s.1., 12(7/9): 291-7, 1952.

SHARMA, R.D; PEREIRA, J; RESCK, D.V.S. Eficiência de adubos verdes no controle de nematóides associados à soja nos cerrados. Planaltina, EMBRAPA/CPAC, 1982. 30p. (Boletim de Pesquisa, 13)

SIDIRAS, N.; DERPSCH, R; HEINZMANN, F.X. Influência da adubação verde de inverno e seu efeito residual sobre o rendimento nas culturas de verão, em latossolo roxo distrófico. Plantio Direto, Ponta Grossa, 2(9): 4-5, 1984.

SILVA, F.T. \& CHAVES, R.N.M. Estudo sobre recuperação de solos e competição de leguminosas na produção de milho. Agronomia, 24:23-8, 1966.

TEDESCO, M.J. Matéria orgânica e nitrogênio. In: CURSO DE ATUALIZAÇÃO EM FERTILIDADE DO SOLO. Londrina, 1983. p.87-123.

TEIXEIRA, L.A.J. Fornecimento de nitrogênio ao milho por sistemas de culturas. Porto Alegre, UFRGS, 1988. 96p. (Dissertação de Mestrado, Solos).

TISDALE, S.L. \& NELSON, W.L. Soil fertility and fertilizers. New York, Macmillan Publishing Co, 1975. 645p.

THOMPSON, L.M. Soils and fertility. New York, Mac Graw-Hill, 1952. 339p. 
VERDADE, F.C. Influência da matéria orgânica na capacidade de troca de cátions do solo. Bragantia, Campinas, 15(4):35-45, 1956.

VIETS Jr, F.S. \& HAGEMANN, R.H. Factors effectivo the accumulation of nitrate in soil water and plants. Washington, 1971. 63p.

VITTI, G.C; FERREIRA, M.E.; PERECIN, D.; ZANETTI NETO, P. Influência de cinco leguminosas como adubação verde na fertilidade de um Latossolo Vermelho fase arenosa (LVa). Científica, 7 (3):431-5, 1979.

VITTI, G.C. Amostragem e interpretação de análise de solo e de folha na citricultura. Jaboticabal, FUNEP, 1988. 32p.

WHITE, R.O; NILSSON-LEISSNER, G.N.; TRUMBLE, H.C. Las leguminosas en la agricultura. Roma, FAO, 1955. 403p. 


\section{APÊNDICE}

$\mathrm{Na}$ Tabela 25, são apresentados o índice pluviométrico e a temperatura, ocorrido no período de 06/1989 a 06/1993, coletados no posto meteorológico da E.E.C.B.

TABELA 25. Dados climáticos no período de junho / 1989 a junho / 1993.

\begin{tabular}{cccccc}
\hline Mês & Ano & $\begin{array}{c}\text { Precipitação } \\
(\mathrm{mm})\end{array}$ & \multicolumn{3}{c}{ Temperatura $\left({ }^{\circ} \mathrm{C}\right)$} \\
\cline { 4 - 6 } & & 48,9 & 13,9 & 26,1 & 20,0 \\
\hline 06 & 1989 & 35.2 & 13.0 & 25.6 & 19.3 \\
07 & 1989 & 22.4 & 15.6 & 28.2 & 21.9 \\
08 & 1989 & 62.6 & 17.6 & 30.1 & 23.8 \\
09 & 1989 & 68.8 & 18.3 & 30.7 & 24.5 \\
10 & 1989 & 146.9 & 20.0 & 30.6 & 25.3 \\
11 & 1989 & 350.9 & 20.3 & 29.8 & 25.1 \\
12 & 1989 & 735.7 & 17.0 & 28.7 & 22.8 \\
\hline total/médias & 1903.4 & 21.4 & 30.7 & 26.0 \\
\hline 01 & 1990 & 91.9 & 20.9 & 30.5 & 25.7 \\
02 & 1990 & 310.6 & 20.6 & 29.5 & 25.1 \\
03 & 1990 & 143.5 & 20.0 & 27.5 & 23.7 \\
04 & 1990 & 88.7 & 15.3 & 24.1 & 19.7 \\
05 & 1990 & 0.0 & 14.2 & 23.4 & 18.8 \\
06 & 1990 & 24.6 & 13.1 & 23.9 & 18.5 \\
07 & 1990 & 170.6 & 15.0 & 26.0 & 20.5 \\
08 & 1990 & 34.0 & 14.4 & 29.3 & 21.9 \\
09 & 1990 & 100.1 & 19.5 & 32.6 & 26.1 \\
10 & 1990 & 189.2 & 19.8 & 33.1 & 26.5 \\
11 & 1990 & 183.6 & 20.4 & 33.5 & 27.0 \\
\hline 12 & 1990 & 1540.2 & 17.9 & 28.7 & 23.3 \\
\hline total/médias & & & & \\
\hline
\end{tabular}

Continua 


\begin{tabular}{|c|c|c|c|c|c|}
\hline \multirow[t]{2}{*}{ Mês } & \multirow[t]{2}{*}{ Ano } & \multirow{2}{*}{$\begin{array}{c}\text { Precipitação } \\
\text { (mm) }\end{array}$} & \multicolumn{3}{|c|}{ Temperatura $\left({ }^{\circ} \mathrm{C}\right)$} \\
\hline & & & Mínima & Máxima & Média \\
\hline 01 & 1991 & 464.4 & 19.5 & 30.5 & 25.0 \\
\hline 01 & 1991 & 195.7 & 20.9 & 32.5 & 26.9 \\
\hline 03 & 1991 & 289.8 & 20.2 & 30.0 & 25.1 \\
\hline 04 & 1991 & 192.4 & 18.6 & 31.4 & 25.0 \\
\hline 05 & 1991 & 34.6 & 14.4 & 28.7 & 21.6 \\
\hline 06 & 1991 & 1.4 & 14.1 & 29.5 & 21.8 \\
\hline 07 & 1991 & 15.6 & 12.1 & 27.2 & 19.7 \\
\hline 08 & 1991 & 0.0 & 14.6 & 31.2 & 22.9 \\
\hline 09 & 1991 & 50.4 & 17.0 & 34.4 & 25.7 \\
\hline 10 & 1991 & 114.6 & 18.0 & 32.1 & 25.1 \\
\hline 11 & 1991 & 108.0 & 19.9 & 33.1 & 26.0 \\
\hline 12 & 1991 & 252.5 & 19.9 & 31.0 & 25.4 \\
\hline \multicolumn{2}{|c|}{ total / médias } & 1719.4 & 17.4 & 31.0 & 24.2 \\
\hline 01 & 1992 & 261.5 & 19.9 & 32.9 & 26.4 \\
\hline 02 & 1992 & 351.4 & 18.3 & 31.1 & 24.9 \\
\hline 03 & 1992 & 193.2 & 18.3 & 30.6 & 24.5 \\
\hline 04 & 1992 & 131.9 & 17.7 & 29.9 & 23.7 \\
\hline 05 & 1992 & 56.0 & 15.5 & 28.6 & 22.1 \\
\hline 06 & 1992 & 0.0 & 13.2 & 28.9 & 21.1 \\
\hline 07 & 1992 & 52.0 & 12.4 & 28.1 & 20.3 \\
\hline 08 & 1992 & 9.5 & 13.9 & 29.1 & 21.5 \\
\hline 09 & 1992 & 134.1 & 15.6 & 27.4 & 21.5 \\
\hline 10 & 1992 & 162.3 & 17.6 & 30.9 & 24.3 \\
\hline 11 & 1992 & 296.7 & 18.0 & 30.4 & 24.2 \\
\hline 12 & 1992 & 141.5 & 18.3 & 31.7 & 25.0 \\
\hline \multicolumn{2}{|c|}{ total / médias } & 1790.1 & 16.6 & 30.0 & 23.3 \\
\hline 01 & 1993 & 142.1 & 31.9 & 18.9 & 25.4 \\
\hline 02 & 1993 & 326.6 & 30.0 & 18.7 & 24.4 \\
\hline 03 & 1993 & 132.0 & 32.3 & 18.5 & 25.4 \\
\hline 04 & 1993 & 64.6 & 31.3 & 16.9 & 24.1 \\
\hline 05 & 1993 & 66.6 & 28.8 & 13.9 & 21.4 \\
\hline 06 & 1993 & 44.0 & 27.1 & 12.2 & 19.7 \\
\hline \multicolumn{2}{|c|}{ total / médias } & 775.9 & 30.2 & 16.5 & 23.4 \\
\hline
\end{tabular}

